Review

\title{
Synthetic Strategies, Reactivity and Applications of 1,5-Naphthyridines
}

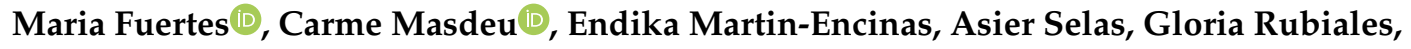 \\ Francisco Palacios * and Concepcion Alonso *iD \\ Departamento de Química Orgánica I, Facultad de Farmacia, Universidad del País Vasco/Euskal Herriko \\ Unibertsitatea (UPV/EHU), Paseo de la Universidad 7, 01006 Vitoria-Gasteiz, Spain; \\ maria.fuertes@ehu.eus (M.F.); carmen.masdeu@ehu.eus (C.M.); endika_690@hotmail.com (E.M.-E.); \\ asier.selas@ehu.eus (A.S.); gloria.rubiales@ehu.eus (G.R.) \\ * Correspondence: francisco.palacios@ehu.es (F.P.); concepcion.alonso@ehu.eus (C.A.)
}

Academic Editors: Philippe Belmont, Richard A. Bunce, Wim Dehaen and Eugene Babaev Received: 29 June 2020; Accepted: 15 July 2020; Published: 16 July 2020

\begin{abstract}
This review covers the synthesis and reactivity of 1,5-naphthyridine derivatives published in the last 18 years. These heterocycles present a significant importance in the field of medicinal chemistry because many of them exhibit a great variety of biological activities. First, the published strategies related to the synthesis of 1,5-naphthyridines are presented followed by the reactivity of these compounds with electrophilic or nucleophilic reagents, in oxidations, reductions, cross-coupling reactions, modification of side chains or formation of metal complexes. Finally, some properties and applications of these heterocycles studied during this period are examined.
\end{abstract}

Keywords: 1,5-naphthyridines; heterocycle synthesis; metal complexes; biological activity

\section{Introduction}

The focus of this review is on the collection of recent advances in the synthesis, reactivity and applications of the 1,5-naphthyridines that have been published in the last 18 years, excluding fused 1,5-naphthyridine analogues. Several reviews have appeared in the naphthyridine area [1-4], so the coverage of this review is not designed to overlap with these contributions, and therefore, references are, in general, presented from 2003 to the present.

The first derivative of the cyclic naphthyridine system (a 1,8-naphthyridine) was obtained in 1893 by Reissert [5], who proposed this name for the new class of heterocyclic derivatives, since naphthyridine was considered to be the naphthalene analog, containing two fused pyridine rings with different mutual arrangements of nitrogen atoms. As indicated in Figure 1, six isomeric naphthyridines are possible:

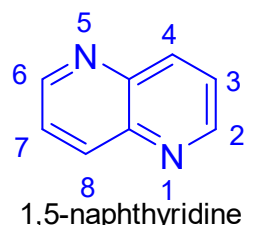<smiles>c1cnc2ccncc2c1</smiles>
1,6-naphthyridine<smiles>c1cc2cnccc2cn1</smiles>

2,6-naphthyridine<smiles>c1cnc2cnccc2c1</smiles><smiles>c1cnc2ncccc2c1</smiles>

1,7-naphthyridine 1,8-naphthyridine<smiles>c1cc2cnccc2cn1</smiles>

2,7-naphthyridine

Figure 1. Structures of isomeric naphthyridines. 
Over the years, these ring systems have received various names, such as "pyridopyridines", "benzodiazines", "diazadecalins" or by the "aza" system when named as "diazanaphthalene". Finally, in 1936, these compounds were indexed in Chemical Abstracts as "naphthyridines".

In 1927 Brobansky and Sucharda reported the synthesis of the first representatives of unsubstituted naphthyridines, precisely 1,5-naphthyridines, by adapting the Skraup quinoline synthesis to 3-aminopyridine [6]. Since then, several researchers have published their work on the chemistry of 1,5-naphthyridines. From the year 2000, there are over 600 published papers related only to 1,5-naphthyridine, 400 of them as patents.

The great interest in 1,5-naphthyridines is caused by the wide variety of applications. Among them, biological activities as for example antiproliferative, antibacterial, antiparasitic, antiviral and anti-inflammatory activities could be highlighted. They find application in the cardiovascular, central nervous system and hormonal diseases. In addition, chemical applications as ligands in analytical chemistry or hydrogen acceptors and as organic light-emitting diodes (OLEDs), sensors, semiconductors, solar cells, among others have been considered.

This paper, first, summarizes the work published from 2003, involving the synthesis of 1,5-naphthyridines. Following that that, the reactivity of the compounds giving rise to substituted 1,5-naphthyridines, including several metal complexes, will then be presented. Finally, some properties and applications of these heterocycles studied during this period are reviewed.

\section{Synthesis of 1,5-Naphthyridines}

Synthetic methods such as cyclization (including Skraup and Friedländer reactions among others), inter- and intramolecular cycloaddition processes (including Povarov reaction, [3+2] cycloadditions, etc.) and other reactions like cross coupling reactions were used to prepare 1,5-naphthyridines. Many of these methods have been well described in previously published reviews [4].

\subsection{Synthesis of 1,5-Naphthyridines by Cyclization Reactions}

The simplest Skraup reaction has been used for the synthesis of 1,5-naphthyridine derivatives from substituted 3-aminopyridine compounds $\mathbf{1}$ and glycerol using different catalyst such as iodine, $\mathrm{NaNO}_{2}, \mathrm{KI}, \mathrm{KIO}_{3}, \mathrm{MnO}_{2}$ or $\mathrm{KMnO}_{4}$. Good results were obtained when iodine was used as catalyst in a mixture of dioxane/water (1/1), which is cheap, easy handling and can be recovered and reused efficiently up to five times [7]. Likewise, $m-\mathrm{NO}_{2} \mathrm{PhSO}_{3} \mathrm{Na}$ was used as an oxidant for the preparation of 1,5-naphthyridines 2 (Scheme 1), which displayed a higher yield (45-50\%) and a better reproducibility than $\mathrm{I}_{2}$ [8]. Additionally, the 3-bromo-1,5-naphthyridine $\mathbf{2 b}$ [9], was reached through a modified Skraup reaction using $m-\mathrm{NO}_{2} \mathrm{PhSO}_{3} \mathrm{Na}$ [10]. 2-Methyl- [11] and 3-methoxy-4-methyl-1,5-naphthyridines 2c-2e [12-14] (Scheme 1) were also reported.

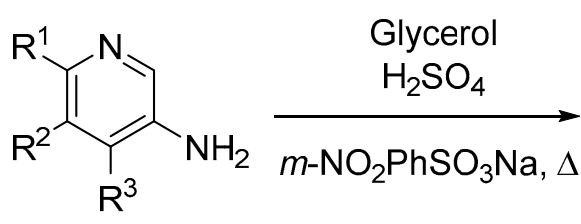

1<smiles>[R]c1nc2cccnc2c([R])c1[R]</smiles>

2

$$
\begin{aligned}
& \text { a } \mathrm{R}^{1}=\mathrm{R}^{2}=\mathrm{R}^{3}=\mathrm{H} \\
& \text { b } \mathrm{R}^{1}=\mathrm{H} ; \mathrm{R}^{2}=\mathrm{Br} ; \mathrm{R}^{3}=\mathrm{H} \\
& \text { c } \mathrm{R}^{1}=\mathrm{OMe} ; \mathrm{R}^{2}=\mathrm{R}^{3}=\mathrm{H} \\
& \text { d } \mathrm{R}^{1}=\mathrm{H} ; \mathrm{R}^{2}=\mathrm{OMe} ; \mathrm{R}^{3}=\mathrm{CH}_{3} \\
& \text { e } \mathrm{R}^{1}=\mathrm{CH}_{3} ; \mathrm{R}^{2}=\mathrm{R}^{3}=\mathrm{H}
\end{aligned}
$$

Scheme 1. Skraup synthesis of 1,5-naphthyridines.

2,8-Dimethyl-1,5-naphthyridine 4a was obtained when 3-amino 4-methyl pyridine 3a $\left(\mathrm{R}^{1}=\mathrm{R}^{2}=\mathrm{H}, \mathrm{R}^{3}=\mathrm{Me}\right)$ reacted with acetaldehyde (Scheme 2$)$. In the same way, starting from 6-methoxy-3-aminopyridine, 2-hydroxy-6-methyl-1,5-naphthyridine $4 \mathbf{b}\left(\mathrm{R}^{1}=\mathrm{OH}, \mathrm{R}^{2}=\mathrm{R}^{3}=\mathrm{H}\right)$ was prepared [15]. In the same context, the reaction of 2-chloro-3,5-diaminopyridine $3 \mathrm{c}\left(\mathrm{R}^{1}=\mathrm{Cl}, \mathrm{R}^{2}=\mathrm{NH}_{2}\right.$, $\mathrm{R}^{3}=\mathrm{H}$ ) in the presence of hexafluoroacetylacetone 5 and montmorillonite k10 as catalyst, yielded the corresponding 1,5-naphthyridine 6 as a yellowish solid (Scheme 2) [16]. 
<smiles>[R]c1nc2ccc(C)nc2c([R])c1[R]</smiles>

4<smiles>[R]c1ncc(N)c([R])c1[R]</smiles>

3 a $\mathrm{R}^{1}=\mathrm{R}^{2}=\mathrm{H} ; \mathrm{R}^{3}=\mathrm{CH}_{3}$

b $\mathrm{R}^{1}=\mathrm{OH} ; \mathrm{R}^{2}=\mathrm{R}^{3}=\mathrm{H}$

c $\mathrm{R}^{1}=\mathrm{Cl} ; \mathrm{R}^{2}=\mathrm{NH}_{2} ; \mathrm{R}^{3}=\mathrm{H}$

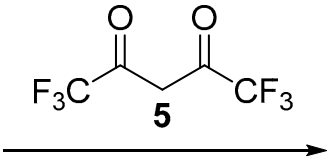

Montmorillonite k10 1,4-dioxane<smiles>Nc1cc2nc(C(F)(F)F)cc(C(F)(F)F)c2nc1Cl</smiles>

6

Scheme 2. Preparation of 1,5-naphthyridines from 3-aminopyridines and carbonyl derivatives.

Gould-Jacobs reaction, reported by Brown and Dewar in 1978 [17], between 3-aminopyridine 7 and diethyl methylenemalonate 8 followed by a thermal cyclization afforded the 1,5-naphthyridine $\mathbf{9 a}$ (Scheme 3) [18]. 4-Hydroxy-1,5-naphthyridine $\mathbf{9 b}$ was also prepared by a condensation reaction at $150{ }^{\circ} \mathrm{C}$ followed by a ring cyclization to yield the 1,5-naphthyridine skeleton (Scheme 3) [19]. Similarly, 1,5-naphthyridine derivative 10a has been obtained [20]. Moreover, in a recent study, the same reaction was applied for the synthesis of 1,5-naphthyridine $\mathbf{1 0 b}$ (Scheme 3). However, in this particular case chlorobenzene was the solvent of choice to carry out the cyclization [21].<smiles>[R]c1cc([R2])c(N)c([R])n1</smiles><smiles>[R]c1cc([R])c2nc([R])c([R])c(O)c2n1</smiles><smiles>[R]COC(=O)C(=CNc1c([R])cc([R16])nc1[R])C(=O)OCC</smiles>

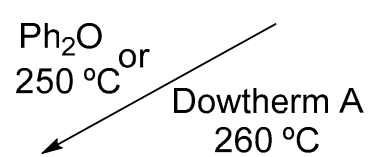
- EtOH<smiles>[R]c1cc([R2])c2[nH]cc([R7])c(=O)c2n1</smiles>

$$
\begin{aligned}
& \text { a } \mathrm{R}^{1}=\mathrm{R}^{2}=\mathrm{R}^{4}=\mathrm{H} ; \mathrm{R}^{5}=\mathrm{CO}_{2} \mathrm{Et} \\
& \text { b } \mathrm{R}^{1}=\mathrm{R}^{4}=\mathrm{H} ; \mathrm{R}^{2}=\mathrm{CH}_{3} ; \mathrm{R}^{5}=\mathrm{CO}_{2} \mathrm{Et} \\
& \text { c } \mathrm{R}^{1}=\mathrm{OMe} ; \mathrm{R}^{2}=\mathrm{H} ; \mathrm{R}^{4}=\mathrm{OH} ; \mathrm{R}^{5}=\mathrm{CO}_{2} \mathrm{Et} \\
& d^{1} R^{1}=\mathrm{OMe} ; \mathrm{R}^{2}=\mathrm{OH} ; \mathrm{R}^{4}=\mathrm{R}^{5}=\mathrm{H} \\
& \text { e } \mathrm{R}^{1}=\mathrm{R}^{4}=\mathrm{R}^{5}=\mathrm{H} ; \mathrm{R}^{2}=\mathrm{OH}
\end{aligned}
$$

$$
\begin{aligned}
& \text { a } \mathrm{R}^{1}=\mathrm{H} ; \mathrm{R}^{2}=\mathrm{OMe} ; \mathrm{R}^{5}=\mathrm{CO}_{2} \mathrm{Et} \\
& \text { b } \mathrm{R}^{1}=\mathrm{Cl} ; \mathrm{R}^{2}=\mathrm{H} ; \mathrm{R}^{5}=\mathrm{CO}_{2} \mathrm{Et} \\
& \text { c } \mathrm{R}^{2}=\mathrm{H} ; \mathrm{R}^{5}=\mathrm{CO}_{2} \mathrm{Et} ; \mathrm{R}^{1}=\mathrm{O} \\
& \mathbf{d ~ R}^{1}=\mathrm{OEt} ; \mathrm{R}^{2}=\mathrm{H} ; \mathrm{R}^{5}=\mathrm{CONHPh} \\
& \text { e } \mathrm{R}^{1}=\mathrm{OMe} ; \mathrm{R}^{2}=\mathrm{H} ; \mathrm{R}^{5}=\mathrm{CO}_{2} \mathrm{Et} \\
& f^{1}=\mathrm{H} ; \mathrm{R}^{2}=\mathrm{OMe} ; \mathrm{R}^{5}=\mathrm{CO}_{2} \mathrm{Et} \\
& g^{1}=\mathrm{OMe} ; \mathrm{R}^{2}=\mathrm{H} ; \mathrm{R}^{5}=
\end{aligned}
$$

Scheme 3. Gould-Jacobs reaction for the preparation of 1,5-naphthyridine derivatives.

This reaction was used to synthesize 1,5-naphthyridine derivative 10c [22] and 9d by the condensation followed by a cyclization and decarboxylation [11] (Scheme 3). As well as for 6-ethoxy-4-oxo-1,4-dihydro-1,5-naphthyridine-3-carboxylic acid benzylamide 10d (Scheme 3), including a multikilogram scale synthesis of this compound [23]. This methodology was also applied for the preparation of biologically active compounds [24,25]. The same strategy [26] was used to find 
new methodologies for the late-stage introduction of fluorine into advanced hydroxy-naphthyridine, leading the 1,5-naphthyridone rings in compounds 10e-10f (Scheme 3). Similarly, this process was used for the development of 1,5-naphthyridine 9e (Scheme 3). In this case, formation of the second pyridine ring and the subsequent decarboxylation step were performed by prolonged refluxing in concentrated hydrobromic acid, rather than using quinoline and vacuum-thermal decarboxylation, which sped up and eased the synthesis [27].

Wei et al., following their studies to develop naphthyridine-based $\mathrm{Eu}(\mathrm{III})$ complexes, reported an extension of the method by using methyl-2-cyano-3-methoxybut-2-enoate 12 instead of ethoxymethylene malonate in order to obtain the corresponding 1,5-naphthyridinecarbonitrile derivatives 13a and 13b (Scheme 4) [28,29].

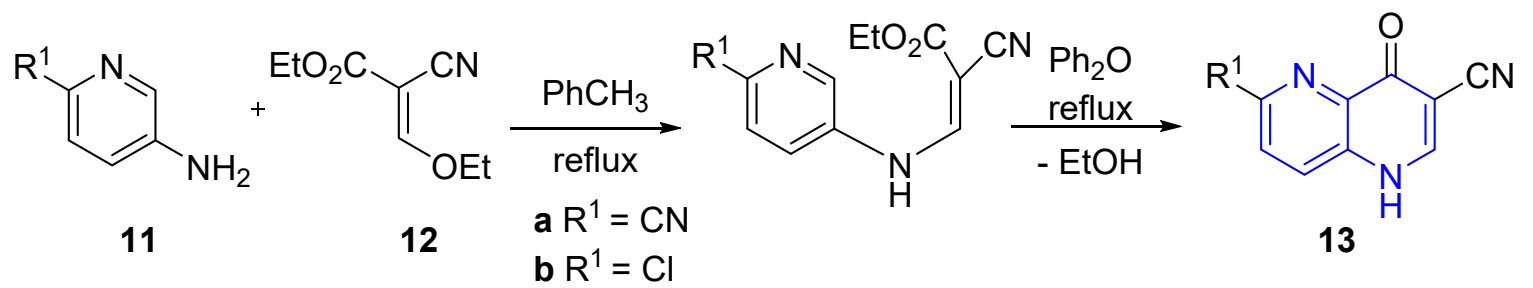

Scheme 4. Modified Gould-Jacobs reaction for the preparation of 1,5-naphthyridinecarbonitriles.

Another of the earliest methods to obtain naphthyridin-4-ones 16 (Scheme 5), which often isomerize (or aromatize) to 4-hydroxyquinolines was the Conrad and Limpach reaction [4]. The reaction consists a thermal condensation of primary aromatic amines 14 with the carbonyl group of $\beta$-ketoesters 15 followed by the cyclization of the corresponding Schiff base intermediates [30].
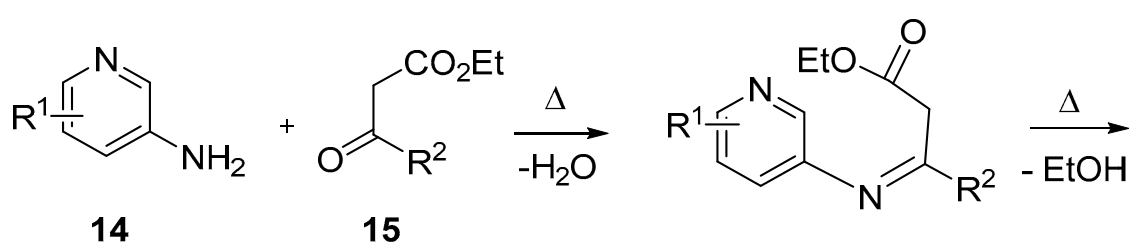<smiles>[R]c1cc(=O)c2nc[R]#cc2[nH]1</smiles>

Scheme 5. Conrad-Limpach reaction with $\beta$-ketoesters for the preparation of 1,5-naphthyridinones.

This reaction was later extended for the use of Meldrum's acid instead of $\beta$-ketoesters to afford 4-hydroxynaphthyridines 19 (Scheme 6). Therefore, the synthesis of the 8-hydroxy-1,5-naphthyridines 19a-d (Scheme 6) has been carried out by reaction between Meldrum's acid and 3-aminopyridine derivatives 17 after condensation [31]. Initially, it furnished the corresponding enamine $\mathbf{1 8}$ in good yields. Ring formation was accomplished by heat-assisted intramolecular cyclization in Dowtherm A or diphenyl ether and the subsequent decarboxylation led to the formation of 8-hydroxy-1,5-naphthyridine 19h (Scheme 6) [32]. Similarly, in the synthesis of some heteroleptic platinum complexes (FPtXND) bearing 4-hydroxy-1,5-naphthyridine the use of Meldrum's acid was also the method of choice using substituted triethyl orthoformate to introduce a substituent at the 8 position of the ring (19a,c,e-g, Scheme 6) [33].

Some 1,5-naphthyridine intermediates for fluorination assays [26] were obtained through a cyclization method involving aminopyridine with Meldrum's acid in triethylformate at $100{ }^{\circ} \mathrm{C}$, and subsequently heating in Dowtherm A at $250{ }^{\circ} \mathrm{C}$ (compound 19a, Scheme 6) [34]. Likewise, this process was used for the preparation of the ligand 8-hydroxy-1,5-naphthyridine-2-carboxylic acid (H2L1) [28], a 2,8-disubstituted-1,5-naphthyridine [35] and compounds 19i,j (Scheme 6) [27].

Another synthetic approach to lead 1,5-naphthyridine consists on cross-coupling reactions followed by cyclization reactions. In this context, the Heck reaction of the corresponding aminopyridine 20 with $\mathrm{Pd}(\mathrm{OAc})_{2}$, tri-tert-butylphosphonium tetrafluoroborate, $\mathrm{N}, \mathrm{N}$-dicyclohexylmethylamine (N-MDCHA) in cumene at $150^{\circ} \mathrm{C}$ overnight yielded an intermediate which evolves by cyclization to 
1,5-naphthyridine 22 [36]. In the same background, a novel electron-accepting bis-lactam building block structurally based on 1,5-dihydro-1,5-naphthyridine-2,6-dione was achieved following the same procedure above mentioned [37]. Similarly, a 1,5-naphthyridine derivative 22 was prepared from 2-bromo-6-fluoropyridin-3-amine 20 using Heck reaction of the substituted pyridine with methyl acrylate 23 in good yield. Cyclization was achieved using $\mathrm{PBu}_{3}$ in $\mathrm{AcOH}$ in excellent yields (Scheme 7) [38].<smiles>[R]c1ncc(N)c([R])c1[R]</smiles><smiles>[R]C(Nc1cnc([R])c([R])c1[R])=C1C(=O)OC(C)(C)OC1=O</smiles>

17

Dowtherm A at $250^{\circ} \mathrm{C}$

or $\mathrm{Ph}_{2} \mathrm{O}$, reflux<smiles>[R]c1cc(=O)c2nc([R])c([R])c([R])c2[nH]1</smiles>

$$
\begin{aligned}
& 19 \text { a } R^{1}=R^{2}=R^{3}=R^{4}=H \\
& \text { b } R^{1}=C_{3} ; R^{2}=R^{3}=R^{4}=H \\
& \text { c } R^{1}=\mathrm{CH}_{3} ; R^{4}=\mathrm{CH}_{3} ; R^{2}=R^{3}=H \\
& \text { d } R^{1}=\mathrm{CH}_{3} ; R^{4}=P h ; R^{2}=R^{3}=H \\
& \text { e } R^{1}=O P h ; R^{2}=R^{3}=R^{4}=H \\
& \text { f } R^{1}=\text { piperidyl; } R^{2}=R^{3}=R^{4}=H \\
& \text { g } R^{1}=\text { carbazolyl; } R^{2}=R^{3}=R^{4}=H \\
& \text { h } R^{2}=B r ; R^{1}=R^{3}=R^{4}=H \\
& \text { i } R^{3}=O M e ; R^{1}=R^{2}=R^{4}=H \\
& \text { j } R^{3}=C N ; R^{1}=R^{2}=R^{4}=H
\end{aligned}
$$

Scheme 6. Conrad-Limpach reaction with Meldrum's acid for the preparation of 1,5-naphthyridinones.<smiles>Nc1cc(F)cnc1Br</smiles>

20

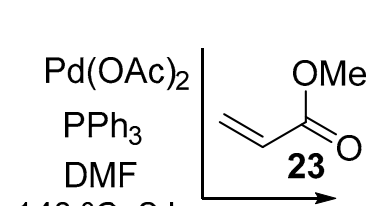

$140^{\circ} \mathrm{C}, 2 \mathrm{~h}$

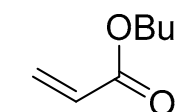

$$
21
$$<smiles>[R]OCCO</smiles>
$\left[\left({ }^{t} \mathrm{Bu}\right)_{3} \mathrm{PH}_{3} \mathrm{BF}_{4}\right.$ $\mathrm{N}-(\mathrm{MDCHA})$ cumene<smiles>COC(=O)/C=C/c1ncc(F)cc1N</smiles>

Scheme 7. Palladium mediated synthesis of 1,5-naphtyridinones from 3-aminopyridines and acrylates. 
A Stille cross-coupling reaction was also used to reach the 1,5-naphthyridine ring. Thus, chloronitropyridine 24 underwent reaction with tributyl(1-ethoxyvinyl)tin 25, which after fluorination and subsequent condensation with DMF-dimethylacetal and followed by the nitro reduction-deoxobromination sequence, resulted in the 1,5-naphthyridine ring $\mathbf{2 6}$ in good yield (Scheme 8) [26].

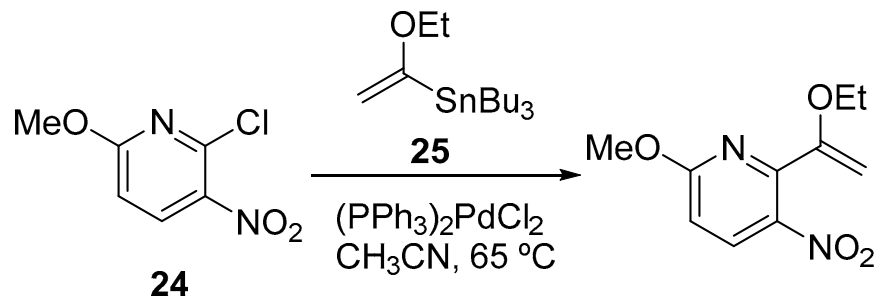<smiles>CCOC(CF)c1nc(OC)ccc1[N+](=O)[O-]</smiles><smiles>CCOC(/C(F)=C/NC(=O)OCc1ccccc1)c1nc(OC)ccc1[N+](=O)[O-]</smiles>

Scheme 8. Synthesis of 1,5-naphthyridines based on Stille cross-coupling reaction.

In another approach, Knochel et al. described the preparation of new conjunctive alkenyl-metal reagents $28(\mathrm{Li}, \mathrm{Mg}, \mathrm{Zn})$, bearing a latent aldehyde function and a silyl group facilitating further functionalization, which may be converted into various carbon-carbon bonds. These versatile building blocks allow the synthesis of various classes of important heterocycles, specially the 1,5-naphthyridine. Using bromonitro pyridine 27 as coupling reagents provided a short access to the valuable 1,5 -naphthyridines $\mathbf{2 9} \mathbf{a}, \mathbf{b}$ in $60 \%$ yield when pyridinium $p$-toluenesulfonate (PPTS) was used (Scheme 9) [39].

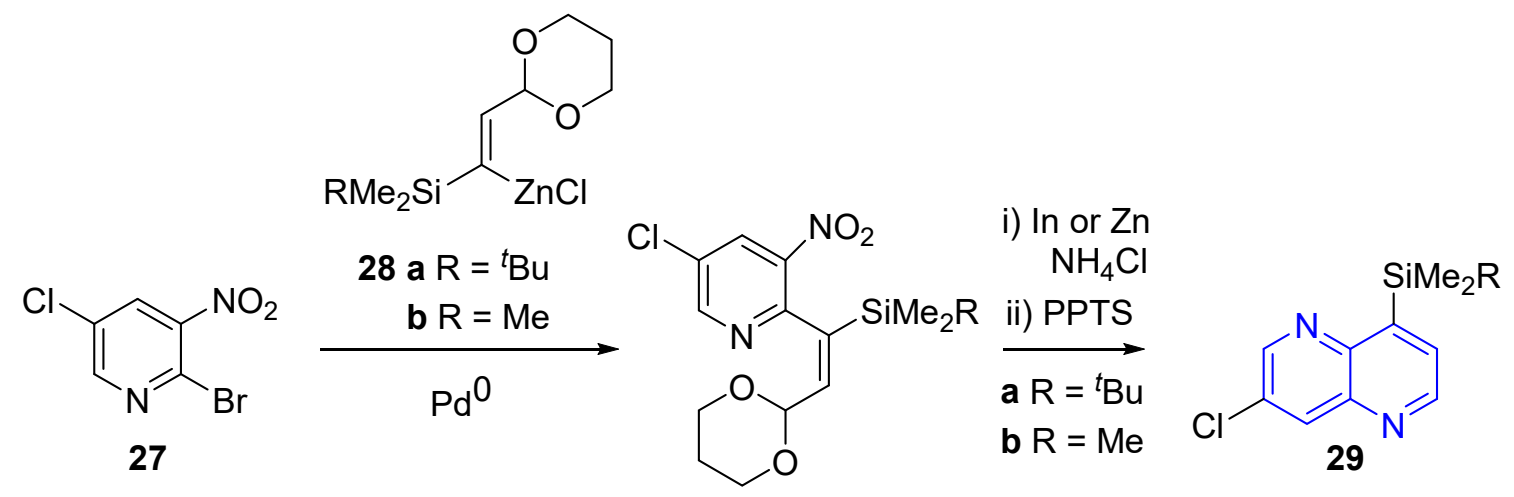

Scheme 9. Knochel approach for the synthesis of 1,5-naphthyridines.

Through an alternative cyclization process, the core of 1,5-naphthyridine 31 was accomplished by treatment of the corresponding pyridine $\mathbf{3 0}$ with diethyl oxalate, subsequent reduction of the nitro and carbonyl functions with aluminium borohydride, followed by concomitant lactamization (Scheme 10) [40]. 


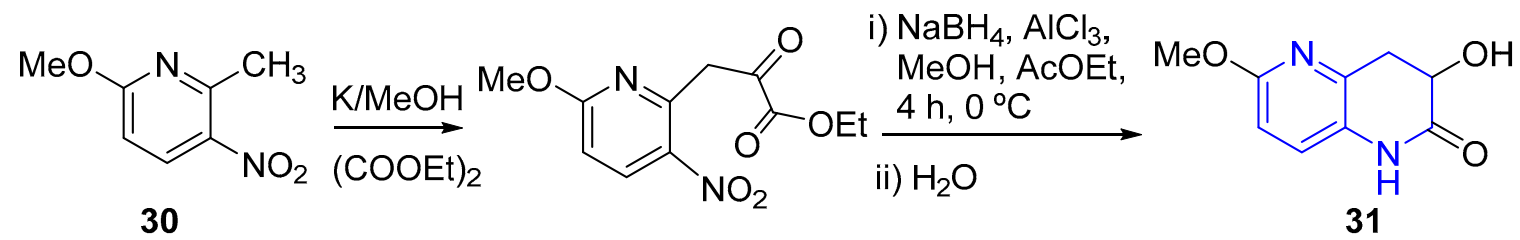

Scheme 10. Synthesis of 3-hydroxy-1,5-naphthyridinone.

On the other hand, our group described the synthesis of 1,5-naphthyridines 34 through an electrocyclic ring closure by reaction between $\mathrm{N}$-(3-pyridyl)aldimines 32 and alkynes 33 (Scheme 11) [41]. The reaction was performed in the presence of a Lewis acid, such as $\mathrm{BF}_{3} \cdot \mathrm{Et}_{2} \mathrm{O}$. Moreover, the combined experimental and computational investigations between $N$-(3-pyridyl)aldimines 32 and acetylenes 33 with a Lewis acid may suggest a stepwise [4+2]-cycloaddition mechanism. The presence of nitrogen in the pyridine ring deactivates the electrophilic substitution with respect to the benzene, yielding the formation of a 3-azatriene whose electrocyclic ring closure (ERC) may give the corresponding heterocyclic intermediates, followed by prototropic tautomerization and subsequent aromatization, to afford naphthyridines 34 (Scheme 11).

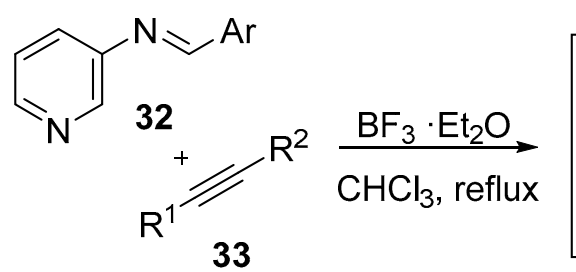<smiles>[R]C=C([R])/C(Br)=N/c1cccnc1</smiles><smiles>[R]c1c(Br)nc2cccnc2c1[R]</smiles>

Scheme 11. [4+2] cycloaddition reaction of imines and acetylenes for the synthesis of 1,5-naphthyridines.

\subsection{Synthesis of 1,5-Naphthyridines by Cycloaddition Reactions}

First, the aza-Diels-Alder reaction (Povarov reaction) [42] activated by Lewis acid has been studied theoretically and experimentally for the synthesis of 1,2,3,4-tetrahydro-1,5-naphthyridine derivatives $\mathbf{3 7} \mathbf{a}$ and $\mathbf{3 7 b}$ (Scheme 12), which can be obtained through endo intermediates in a regio- and stereoselective manner [43]. In the same way, glyoxalate derived 1,5-naphthyridine 37c was prepared through a [4+2] cycloaddition process via endo transition states [44].

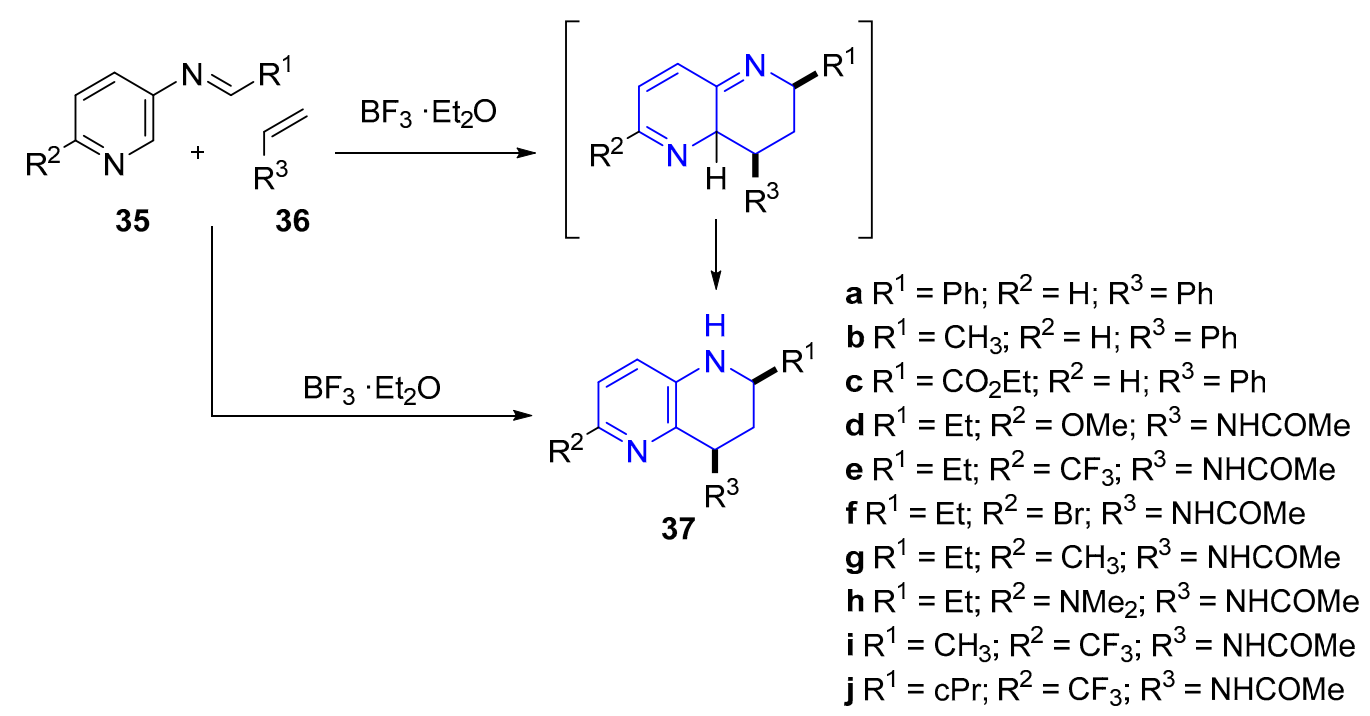

Scheme 12. Aza-Diels-Alder reaction for the synthesis of 1,2,3,4-tetrahydro-1,5-naphthyridines. 
Following this strategy, a series of 4-phenyl-1,5-naphthyridine derivatives were synthesized between imines 35, prepared from 3-aminopyridines and aldehydes, and styrenes 36 as olefins (Scheme 12). The cycloaddition proceeds through endo transition states to afford tetrahydro-1,5-naphthyridines $37 \mathbf{a}-\mathbf{c}$ with the control of two stereocenters. Subsequent aromatization afforded the corresponding 4-phenyl-1,5-naphthyridines [45,46]. 1,5-Naphthyridine derivatives 37d-j were prepared by a modification of a Diels-Alder reaction between aldimines 35, derived from 3-aminopyridine and vinyl acetamide $36\left(\mathrm{R}^{3}=\mathrm{NHCOMe}\right)$ to give the corresponding racemic mixture of the cis isomers (Scheme 12) [47].

\section{Reactivity of $1,5-N a p h t h y r i d i n e s$}

The reactivity pattern of 1,5-naphthyridines shows similarities with quinolines [4]. Therefore, electrophilic substitution including $N$-alkylation reactions, nucleophilic substitution, reduction, oxidation, metalation and cross coupling as well as the modifications in the side chain, metal complex formation and polymerization among other reactions should be considered.

\subsection{Reactions with Electrophilic Reagents}

Reactions in this category applied for pyridine, quinoline and isoquinoline, which involve the donation of the nitrogen lone pair to electrophiles, also occur with the 1,5-naphthyridines [4].

\subsection{1. $N$-alkylation, $N$-acylation and $N$-tosylation}

Alkyl halides react readily with 1,5-naphthyridines to furnish the corresponding $N$-alkylsubstituted 1,5-naphthyridines 40 and 43 (Scheme 13) through quaternary salts intermediates, which undergo base-induced hydrogen halide elimination. In this sense, the alkylation with 2-bromoethanol 39 in the presence of cesium carbonate as a base provided $N$-alkylated 1,5-naphthyridine 40 [36]. Similarly, the same procedure was used to dialkylate 1,5-naphthyridine-2,6-dione 41 with 1-bromooctane 42 to give derivative 43 [37].

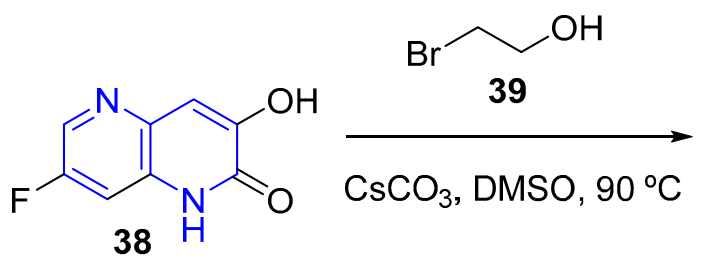<smiles>O=c1c(O)cc2ncc(F)cc2n1CCO</smiles><smiles>O=c1ccc2[nH]c(=O)ccc2[nH]1</smiles>
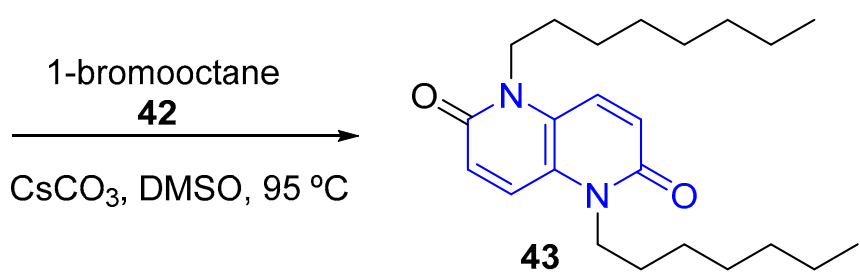

Scheme 13. $N$-alkylation reaction of 1,5-naphthyridinones.

Snyder et al. studied the use of tetrahydro-1,5-naphthyridines as scaffolds to construct a compound library (Scheme 14). Through the reactivity of the N1 nitrogen as a nucleophile with a wide range of electrophilic reagents such as isocyanates, homopropargylic acid, tosyl halides, epoxides, and in cross-coupling processes, the pyridine ring was modified to prepare a 24 membered library [48]. 


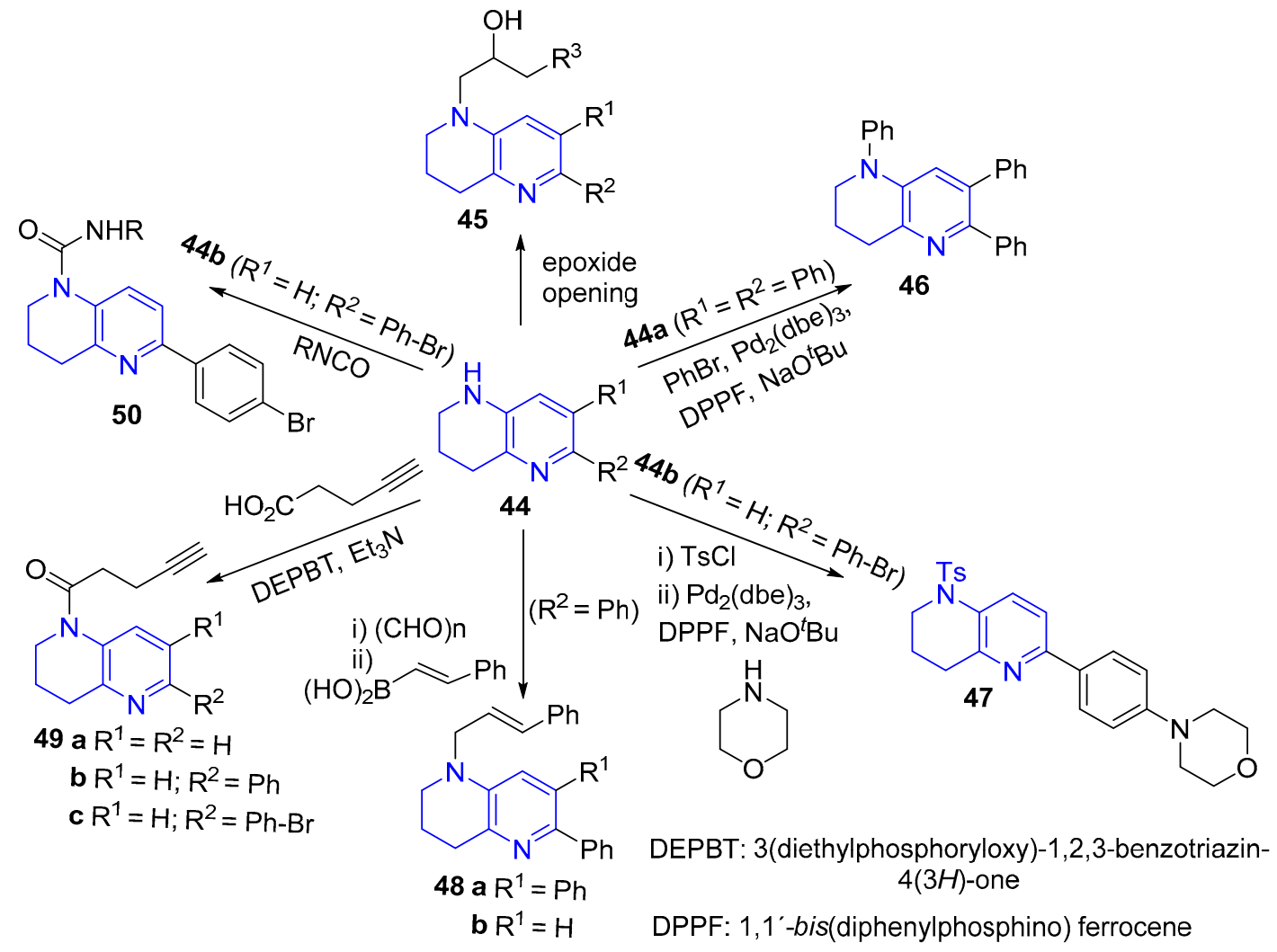

Scheme 14. $N$-functionalization reactions of 1,5-naphthyridines.

\subsubsection{Halogen Substitution at Carbon}

(a) Fluorination

Diazotation-fluorodediazoniation is a useful method for the regioselective introduction of fluorine into aromatic rings. However, two major risks have to be assessed when scaling up this process. First, the thermal instability of the diazonium salt might lead to premature loss of nitrogen (sudden pressure build up) so prolonged storage in tanks or transfer through lines is dangerous. In addition, some diazonium salts are friction sensitive and explode after subjection to mechanical stress. Second, the fluorodediazoniation, the release of nitrogen, is performed at elevated temperature and the exothermic reaction, gas evolution, foaming, and accumulation have to be controlled. To perform the reaction, firstly, the diazonium tetrafluoroborate was prepared with tert-butylnitrite and $\mathrm{BF}_{3} \cdot \mathrm{Et}_{2} \mathrm{O}$ in tetrahydrofuran (THF). The diazonium salt was then dosed in portions to heptane at $85^{\circ} \mathrm{C}$ to trigger the fluorodediazoniation to the fluorinated 1,5-naphthyridine $\mathbf{5 2}$ in good yields (see method A, Scheme 15). In an effort to find new methodologies for the late-stage introduction of fluorine into advanced intermediates, two new strategies have been described. The introduction of the fluorine was accomplished employing lower-cost fluorination reagents $\mathrm{HF}$ or $\mathrm{F}_{2}$ gas, both being routinely used on large scale by specialists in the fine chemicals industry. Then, the one-pot diazotation-fluorodediazoniation protocol of 1,5-naphthyridine 51 with $\mathrm{NaNO}_{2}$ in $\mathrm{HF}$ or pyridine/HF was an attractive option for scale-up as it afforded the fluorinated compound $\mathbf{5 2}$ in high yield (see method B, Scheme 15).

An additional alternative was offered by the surprisingly selective ortho-fluorination of hydroxy-naphthyridines $\mathbf{5 3}$ with $\mathrm{F}_{2}$ gas, without the ubiquitous tarry byproducts reported for such transformations (Scheme 16). A critical parameter was the mass transfer, hence the dispersion of $\mathrm{F}_{2}$ gas in the mixture, and the work-up. The preferred solvent was concentrated $\mathrm{H}_{2} \mathrm{SO}_{4}$. It might be worthwhile to further investigate other solvents (ideally acidic solvents that can be removed by distillation) with additives (e.g., $\mathrm{HBF}_{4}$ ) that will facilitate the work-up of fluorohydroxynaphthyridine 54 [26]. 


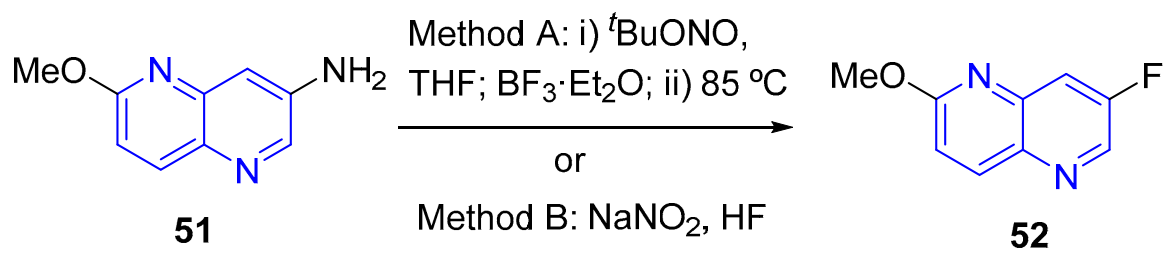

Scheme 15. Diazotation-fluorodediazoniation sequence for the synthesis of fluorinated 1,5-naphthyridine.<smiles>COc1ccc2nccc(O)c2n1</smiles>

53<smiles>COc1ccc2ncc(F)c(O)c2n1</smiles>

54

Scheme 16. ortho-Fluorination of hydroxy-1,5-naphthyridines with fluor gas.

(b) Chlorination

Incorporation of chlorine in 1,5-naphthyridine derivatives may be favored by means of peracids involving the initial formation of the corresponding mono $\mathrm{N}$-oxide derivatives (vide infra, Section 3.3.1.b).

(c) Bromination

Bromination of 1,5-naphthyridine $\mathbf{2 a}$ are often carried out to obtain valuable intermediates for further functionalization. As an example, bromination with bromine in acetic acid (Scheme 17) was used in the synthesis of 1,5-naphthyridine derivative $\mathbf{2} \mathbf{b}$ (previously prepared, vide supra, Scheme 1) [9].

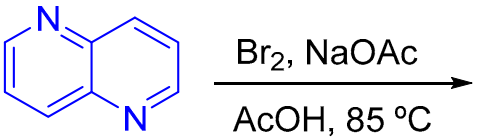

$2 a$<smiles>Brc1cnc2cccnc2c1</smiles>

2b

Scheme 17. Bromination of 1,5-naphthyridine.

Dibromated compound was obtained when 1,5-dialkyl-1,5-naphthyridine-2,6-dione 43 (previously prepared, vide supra, Scheme 13) was treated with bromine to obtain 3,7-dibromo-1,5-dioctyl-1,5-naphthyridine-2,6-dione 55 (Scheme 18) as a suitable intermediate to perform next coupling reactions [37]. The same group, in further studies, used $\mathrm{N}$-bromosuccinimide (NBS), as a bromine source, to synthesize more conjugated polymers [49].

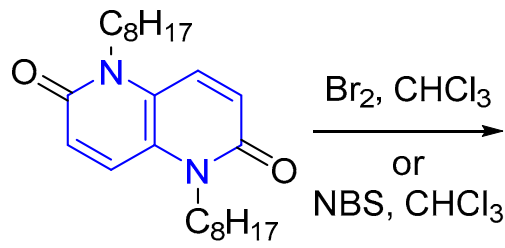

43

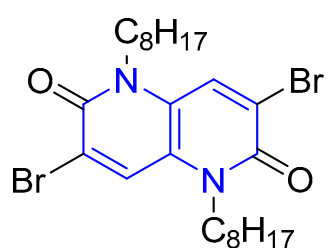

55

Scheme 18. Dibromination of 1,5-naphthyridine-2,6-diones. 


\subsection{Reactions with Nucleophilic Reagents}

\subsubsection{Perfluoroalkylation}

Due to the importance of introducing perfluoroalkyl groups in order to improve the functions of organic molecules [50], Kuninobu et al. developed a regioselective direct C-H trifluoromethylation, pentafluoroethylation, and heptafluoropropylation of 1,5-naphthyridines, using perfluoroalkyltrimethylsilane, trifluoroacetic acid, $\mathrm{KHF}_{2}$, and 1,3-dimethyl-3,4,5,6-tetrahydro-2(1H)pyrimidinone (DMPU). The key step of the reaction consists of dual activation of both $N$-heteroaromatic substrates and trifluoromethyltrimethylsilane by hydrogen fluoride (HF) through the formation of a six-membered transition state. In this way, 1,5-naphthyridine 56 was selectively trifluoromethylated at C-2 in 32\% yield (compound 57, Scheme 19). It is important to highlight that the reaction proceeded with high functional group tolerance, including an oxidation-sensitive formyl group, which might not be tolerated under the previous conditions [51].

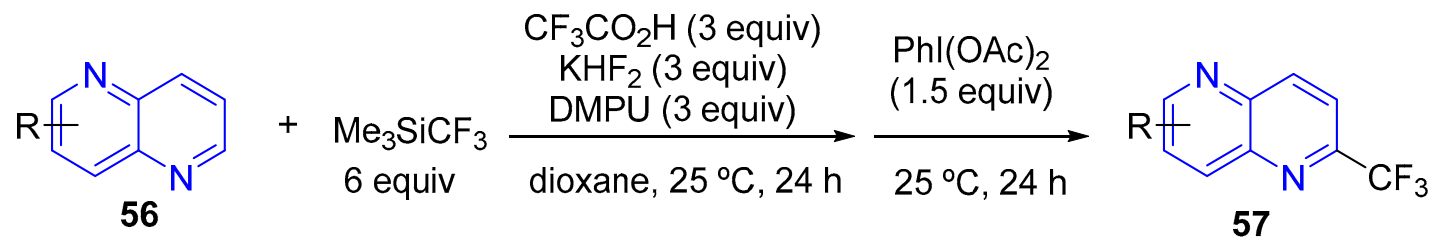

Scheme 19. Trifluoromethylation of 1,5-naphthyridines.

However, the first four-position-selective $\mathrm{C}-\mathrm{H}$ perfluoroalkylation and perfluoroarylation of six-membered heteroaromatic compounds were achieved using nucleophilic perfluoroalkylated and perfluoroarylated reagents promoted by bulky borane Lewis acid. The regioselectivity was controlled by activating the heteroaromatic rings, while sterically hindering the two-position, with a bulky borane Lewis acid. The reaction proceeded to give 1,5-naphthyridine 59 in good yield (59\%), even in gram scale, and by a sequential reaction involving tetrabutylammonium difluorotriphenylsilicate (TBAT) followed by the treatment with [bis(trifluoroacetoxy)iodo]benzene without isolating the intermediates (Scheme 20). This reaction could be applied to late stage trifluoromethylation of a bioactive compound [52].

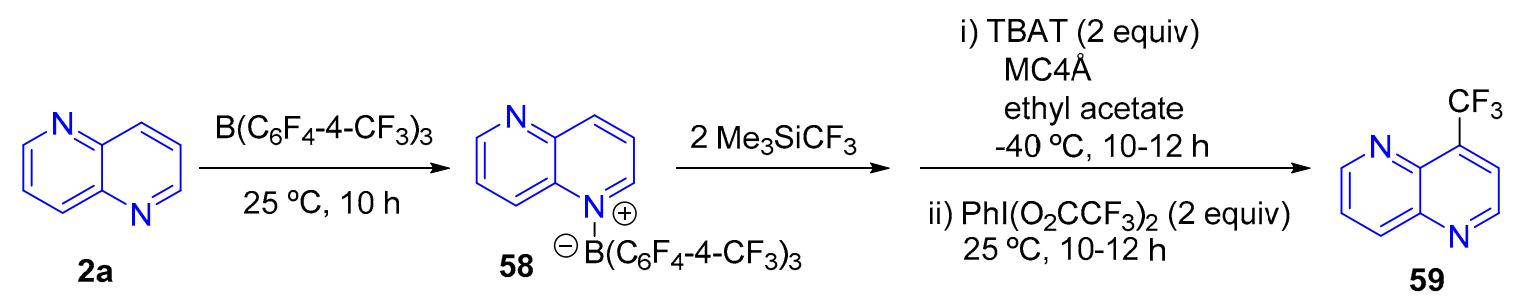

Scheme 20. Trifluoromethylation of 1,5-naphthyridines mediated by boranes.

\subsubsection{Cyanation}

The incorporation of a cyano group into the heterocyclic ring of 1,5-naphthyridine (Scheme 21) was achieved by the formation of mono $N$-oxide or di- $N$-oxide derivatives (vide infra, Section 3.3.1). However, nucleophilic displacement of the triflate with cyano group in compound 60 produced the corresponding C-2 cyano derivatives 61 [53]. 
<smiles>[X]c1cnc2ccc(O)nc2c1CCC12CCC(N[R16]([H])([H])[H])(CO1)CC2(N)O</smiles>

60<smiles>[X]c1cnc2ccc(C#N)nc2c1CCC12CCC(NC(C)(C)C)(CC1)CO2</smiles>

61 a $X=F$

b $X=C N$

Scheme 21. Metal catalyzed cyanation of 1,5-naphthyridines.

\subsubsection{Direct Amination}

Besides direct introduction of an amino group by a Chichibabin reaction [4], functionalization at C-4 can be achieved by a direct deprotometalation-amination reaction (Scheme 22). This methodology appears complementary to access to several 4-amino substituted 1,5-naphthyridines 62a-c [54].

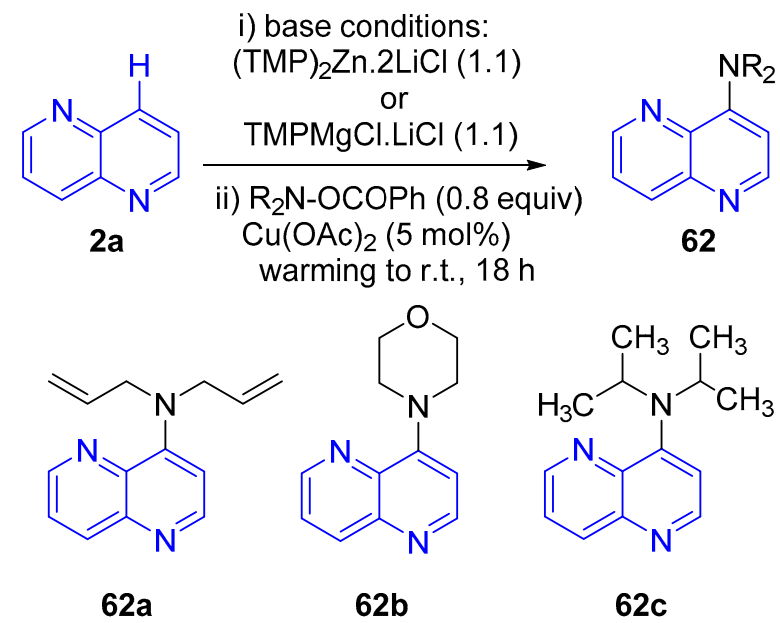

Scheme 22. Deprotometalation-amination reaction of 1,5-naphthyridines.

Grzegozek et al. reported the synthesis of 4-methylamino-3-nitro-1,5-naphthyridine 63 (Scheme 23) by a methylamination reaction of some 2-substituted-3-nitro-1,5-naphthyridine derivatives 64 with a solution of potassium permanganate in liquid methylamine [55].

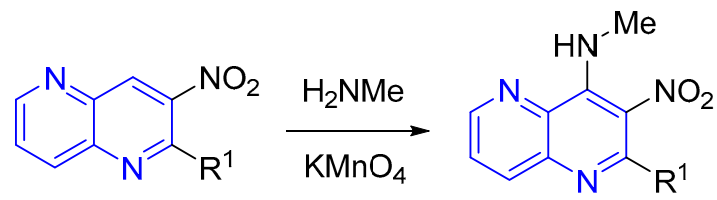

64

63

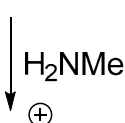

$\checkmark \oplus$

$\mathrm{KMnO}_{4}$

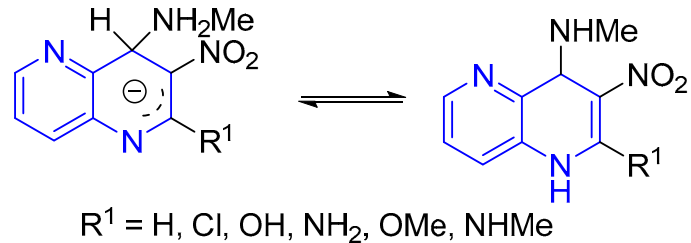

Scheme 23. Amination of nitro-1,5-naphthyridines. 


\subsubsection{Phosphorylation}

Aminophosphonates and their corresponding aminophosphonic acids are known as amino acid mimetics and, therefore, affect the physiological activity of the cell $[56,57]$. The synthesis of 3-phosphonylated aminophosphonates from $\alpha, \beta$-unsaturated imines through tandem 1,4-1,2-phosphite addition was first accomplished by the use of both silylated dialkyl phosphite and trialkyl phosphates [58]. Diphosphonylated diazaheterocyclic compounds 65 were synthesized in a single step reaction by using dimethyl trimethylsilyl phosphite (DMPTMS) under acidic conditions (Scheme 24) in dry dichloromethane. The reaction of DMPTMS with 1,5-naphthyridine $\mathbf{2 a}$ (previously prepared, vide supra, Scheme 1) yielded the corresponding diphosphonylated product 65 through a tandem 1,4-1,2 addition under microwave conditions. Reactions under reflux and microwave conditions were compared. 1,5-Naphthyridine derived substrates are less reactive than previously investigated quinolines [59].<smiles>c1cnc2cccnc2c1</smiles>

2a

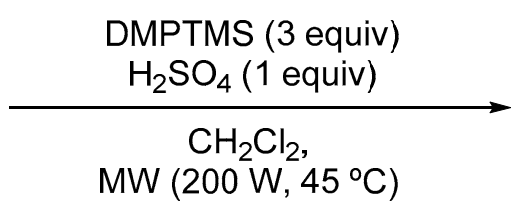

$\underset{\mathrm{H}_{2} \mathrm{SO}_{4}}{\text { DMPTMS }} \downarrow$<smiles>C=CC1CC=Nc2cccnc2C1[PH](C)(OC)OC</smiles><smiles>COC(=O)C1CC=C(N(C)S)c2ncccc21</smiles><smiles>COP(=O)(OC)C1CC(P(=O)(OC)OC)c2ncccc2N1</smiles>

aq. work-up

DMPTMS

1,2-addition<smiles>COP(=O)(OC)C1CC(P(=O)(OC)OC)c2ncccc2N1</smiles>

Scheme 24. Diphosphorylation of 1,5-naphthyridine.

1,5-Naphthyridines containing a diphenylphosphoryl group 66 have been used for the synthesis of tridentate europium(III) complexes and were prepared by a nucleophilic substitution reaction between potassium diphenylphosphanide and compound $\mathbf{6 7}$ followed by hydrogen peroxide oxidation (Scheme 25) [29]. While, phosphonium salts 68 were prepared by the reaction of 1,5-naphthyridine 2a with triarylphosphines and triflic anhydride in the presence of 1,8-diazabicycloundec-7-ene (DBU) [60].<smiles>CC1Nc2ccc(Cl)nc2C(=O)C1C#N</smiles>

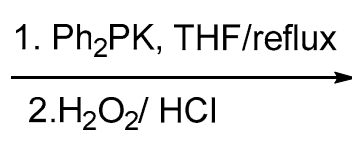<smiles>CC1Nc2ccc(P(=O)(c3ccccc3)c3ccccc3)nc2C(=O)C1C#N</smiles><smiles>[R16]c1ccnc2cccnc12</smiles>

68

Scheme 25. Preparation of 1,5-naphthyridine phosphanoxides and phosphonium salts from chloro-1,5-naphthyridines.

\subsubsection{Halogenation of hydroxy-1,5-naphthyridine and/or 1,5-naphthyridinones}

The conversion of the carbonyl group of 1,5-naphthyridinones into a leaving group has a very important place in the chemistry of these compounds, the most frequently encountered 
examples involving reaction with phosphoryl halide and/or phosphorus pentahalide leading to halo-naphthyridines, through an assumed dihalophosphate intermediate. Given that the halide group is a good leaving group, halo-1,5-naphthyridine derivatives are very interesting intermediates for the introduction of nucleophilic reagents in the 1,5-naphthyridine ring and may be prepared by halogenation of hydroxyl-1,5-naphthyridines. For example, the 1,5-naphthyridine derivatives were prepared [61] and converted into the corresponding 2-chloro derivative 71a using phosphorus oxychloride with 1,5-naphthyridine-2(1H)-one 70a (Scheme 26) [62], and has been used for synthesis of 1,5-naphthyridine functionalized indenyl and cyclopentadienyl ligands. The same strategy has been used for the preparation of chloro-1,5-naphthyridine derivative 71b (Scheme 26) [15]. Chlorination of the carbonyl derivative 70c using $\mathrm{PCl}_{5}$ or $\mathrm{POCl}_{3}$ afforded the corresponding 2-chloro-1,5-naphthyridine 71a (Scheme 26) [63], used for the dimerization of the naphthyridine to obtain 2,2'-bi-1,5-naphthyridine dimer.

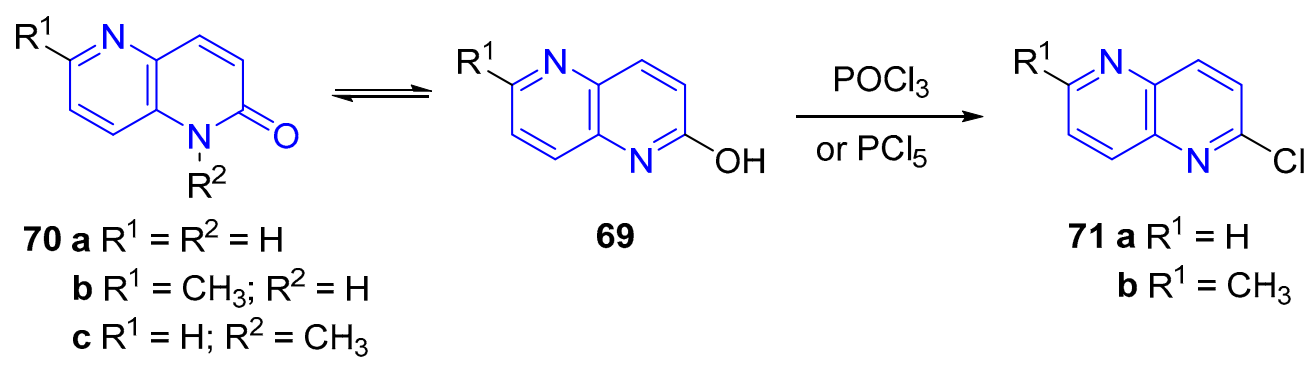

Scheme 26. Chlorination of 1,5-naphthyridine-2(1H)-ones.

On the other hand, chlorination with $\mathrm{POCl}_{3}$ of the 1,5-naphthyridine-4(1H)-one 19a (previously prepared, vide supra, Scheme 6), generated by thermal decarboxylation of 1,5-naphthyridinyl carboxylic acid $9 \mathbf{a}$ (previously prepared, vide supra, Scheme 3) afforded 4-chloro 1,5-naphthyridine 72a (Scheme 27, route A) [18]. Likewise, Lewin et al. reported a new method for the preparation of SB-334867 by a direct halogenation of commercially available 4-hydroxy-1,5-naphthyridine 19a and $19 \mathbf{i}$ (previously prepared, vide supra, Scheme 6) to afford the compounds $\mathbf{7 2 a} \mathbf{a}, \mathbf{b}$ (Scheme 27, route B). This process can also be extended to the formation of 5,8-dichloro-naphthyridine from 5,8-hydroxy-1,5-naphthyridine [64].

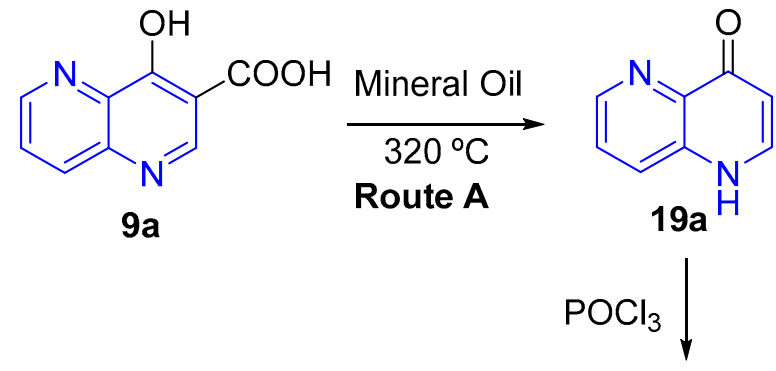

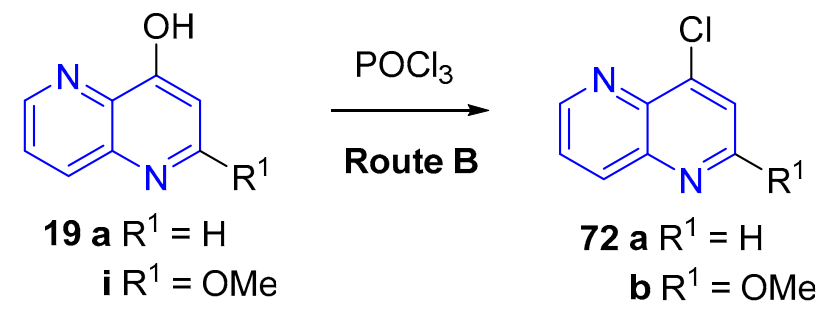

Scheme 27. Chlorination of 1,5-naphthyridine-4(1H)-ones.

Similarly, 1,5-naphthyridine bromide derivatives $\mathbf{7 3}$ and $\mathbf{2 6}$ (previously prepared, vide supra, Scheme 8) were prepared by refluxing the corresponding hydroxyl derivatives 53-54 in neat phosphorus 
tribromide (Scheme 28) [65], while 4,8-dibromo 1,5-naphthyridine has been also synthesized by bromation with $\mathrm{POBr}_{3}$ from 1,5-naphthyridine-4,8(1H,5H)-dione [20].

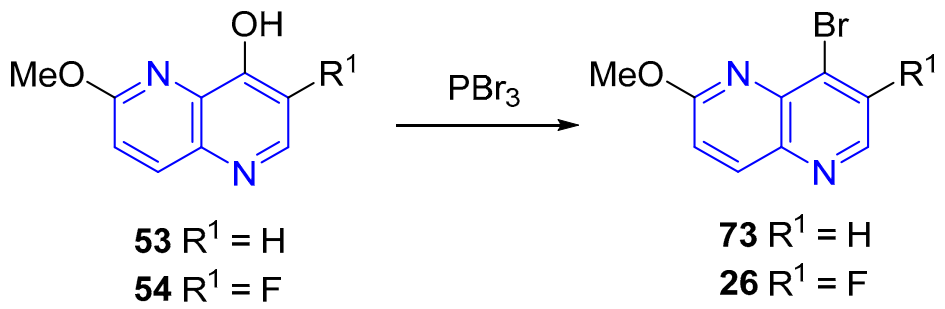

Scheme 28. Bromination of 4-hydroxy-1,5-naphthyridines.

Other halogenation reactions were carried out in the preparation of fluorine intermediates (compounds 74 and 75, Figure 2) [26]. In this sense, the reaction was applied for the synthesis of 1,5-naphthyridine-based polymers, new functional materials for electronics (compound 76, Figure 2) [40], active naphthyridine derivatives for the development of novel anti-Ebola virus pharmacophore (compound 77, Figure 2) [27], a series of naphthyridine derivatives as bromo domain inibitors (compound 72a, Figure 2) [24], for the development of some novel 1,5-naphthyridines as c-Met kinase inhibitors (compound 78, Figure 2) [9], for the synthesis of a 1,5-naphthyridine analogues of a first in class Rpn 11-selective proteasome inhibitor (compound 79, Figure 2) [34] or for the synthesis of 1,5-naphthyridine-based DYRK1A inhibitors (compound 80, Figure 2) [21].<smiles>Fc1cnc2ccc(Cl)nc2c1</smiles>

74<smiles>COc1ccc2ncc([N+](=O)[O-])c(Br)c2n1</smiles>

75<smiles>Brc1ccc2nc(Br)ccc2n1</smiles>

76<smiles>[R]c1ccnc2c([R])ccnc12</smiles>

$77 \mathrm{R}^{1}=\mathrm{R}^{2}=\mathrm{Cl}$

$72 \mathbf{a ~ R}^{1}=\mathrm{H}, \mathrm{R}_{2}=\mathrm{Cl}$<smiles>CCOC(=O)c1cnc2cc(-c3c(C)noc3C)c(OC)nc2c1Cl</smiles><smiles>COc1nc2ccc(Cl)nc2cc1-c1cnn(C)c1</smiles>

79<smiles>[R]c1cnc2ccc(Cl)nc2c1Cl</smiles>

$\mathrm{R}=\mathrm{CO}_{2} \mathrm{Et}, \mathrm{CN}, \mathrm{COMe}$

80

Figure 2. Compounds obtained by halogenation of hydroxy-1,5-naphthyridine derivatives.

\subsubsection{Nucleophilic Substitution with Displacement of Good Leaving Groups}

(a) Amination

Functionalization at C-4 of 1,5-naphthyridine heterocycle 2a can be achieved by a direct deprotometalation-amination reaction (vide supra, Scheme 22) or by an indirect amination. The latter method involves a previously deprotometalation-iodolysis substitution reaction to afford the intermediate 81 (Scheme 29), which permitted the access to a variety of 4-amino substituted 1,5-naphthyridines 62 (previously prepared, vide supra, Scheme 22) [54]. 
<smiles>c1cnc2cccnc2c1</smiles>

2a

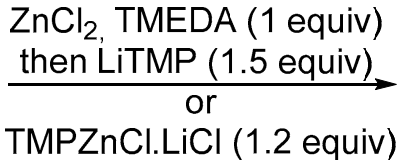
TMPZnCl.LiCl (1.2 equiv)<smiles>Ic1ccnc2cccnc12</smiles>

81<smiles>[R20]c1ccnc2ccc(CC(N)=O)nc12</smiles>

62

Scheme 29. Iodation-amination sequence for the synthesis of 1,5-naphthyridine.

Selective amination by substitution of chlorine atom in 1,5-naphthyridine $82\left(R^{1}=B r, R^{2}=H\right)$, was performed in the presence of ammonium hydroxide in sealed tube at $140{ }^{\circ} \mathrm{C}$ to synthesize the corresponding amines 83 (Scheme 30) [10]. Azidation of 82 with $\mathrm{NaN}_{3}$ followed by reduction with $\mathrm{SnCl}_{2}$, the 1,5-naphthyridine $83\left(\mathrm{R}^{1}=1\right.$-methyl-1H-pyrazol-4-yl, $\left.\mathrm{R}^{2}=\mathrm{OMe}\right)$ scaffold was also obtained in 63\% (Scheme 30) [9].<smiles>[R]c1cc2nc(Cl)ccc2nc1[R]</smiles>

82

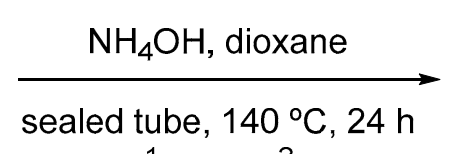

a $R^{1}=B r, R^{2}=H$<smiles>Nc1ccc2ncc(Br)cc2n1</smiles>

83

i) $\mathrm{NaN}_{3}, \mathrm{DMF}, 120^{\circ} \mathrm{C}$

ii) $\mathrm{SnCl}_{2}, \mathrm{HCl}, \mathrm{MeOH}, 60^{\circ} \mathrm{C}$

b R ${ }^{1}=1$-methyl-1H-pyrazol-4-yl, $\mathrm{R}^{2}=\mathrm{OMe}$

Scheme 30. Preparation of 2-amino-1,5-naphthyridine from 2-chloro-1,5-naphthyridine.

Similarly, 4-amino-1,5-naphthyridine 84a has been prepared by a conversion of the 4-chloro-1,5-naphthyridine 72a (previously prepared, vide supra, Scheme 27) with 3-(2-nitro-1imidazolyl)-propylamine [18]. This same methodology was applied by Lewin et al. for the preparation of a intermediate to obtain ligand SB-334867, where by a direct amination of the compound 72a afforded the corresponding derivative $\mathbf{8 4 b}$ in good yields (Scheme 31) [64].

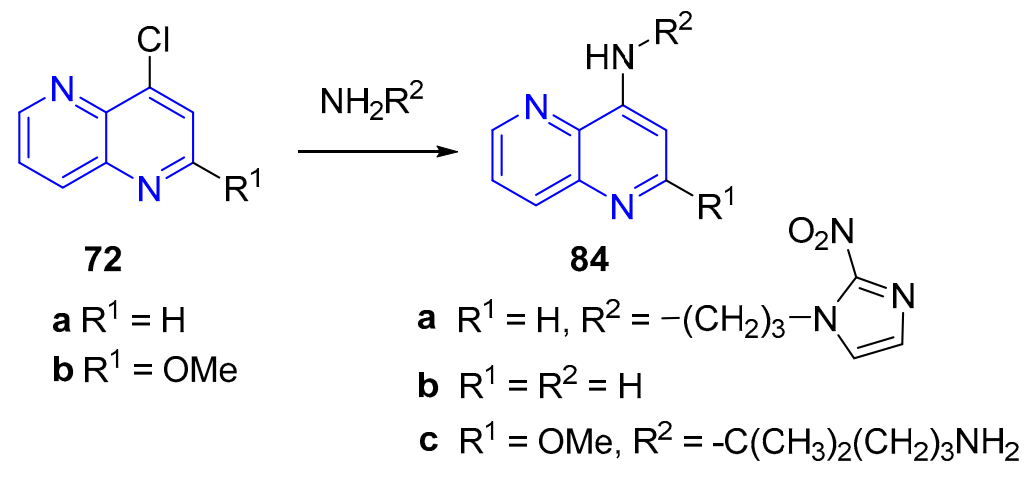

Scheme 31. Amination of 4-chloro-1,5-naphthyridines.

4-Chloro-1,5-naphthyridine $\mathbf{7 2 b}$ (previously prepared, vide supra, Scheme 27) was reacted also with 2-(4-amino-4-methylpentyl)-isoindole-1,3-dione after deprotonation with sodium hydride, in a $\mathrm{S}_{\mathrm{N}} 2$ type mode, which is followed by removal of the protective group on the terminal amine to form 84c (Scheme 31). Whereas, the use of dichloro derivatives 85 led to the formation of functionalized 4-amino-1,5-naphthyridine derivatives 87 , by means of a sequential incorporation of the group followed by the amino moiety (Scheme 32) [11]. 
<smiles>[R]C=CC(=O)NC1(CCCN)CC1</smiles>

Scheme 32. Alkoxylation-amination sequence of dichloronaphthyridine derivatives for the synthesis of alkoxy amino-1,5-naphthyridines.

In this sense, a series of naphthyridine derivatives 88 were prepared in good yields by chlorination followed by thermal condensation with 2-tert-butylaniline (Figure 3) [24]. Recently, the development of a novel anti-Ebola virus pharmacophore, with a 1,5-naphthyridine core, have been reported from chlorinated naphthyridines. These compounds were then subjected to microwave-assisted nucleophilic substitution reactions with appropriate amines. This gave rise to different alkylamino substituted compounds 89 (Figure 3) [27].<smiles>CCOC(=O)c1cnc2cc(-c3c(C)noc3C)c(OC)nc2c1Nc1ccccc1C(C)(C)C</smiles><smiles>[R]Nc1ccnc2cccnc12</smiles>
89 a R $=-\mathrm{CH}\left(\mathrm{CH}_{3}\right)\left(\mathrm{CH}_{2}\right)_{3} \mathrm{~N}\left(\mathrm{CH}_{2} \mathrm{CH}_{3}\right)_{2}$
b $\mathrm{R}=-(\mathrm{CH})_{3} \mathrm{~N}\left(\mathrm{CH}_{2} \mathrm{CH}_{2}\right) \mathrm{O}$
c R $=-\left(\mathrm{CH}_{2}\right)_{3} \mathrm{~N}\left(\mathrm{CH}_{2} \mathrm{CH}_{3}\right)_{2}$
d $\mathrm{R}=-\mathrm{CH}_{2} \mathrm{CH}(\mathrm{OH}) \mathrm{CH}_{2} \mathrm{~N}\left(\mathrm{CH}_{2} \mathrm{CH}_{3}\right)_{2}^{-}$
e $\mathrm{R}=-\left(\mathrm{CH}_{2}\right)_{4} \mathrm{NHR}$<smiles>[R]Nc1c([R])cnc2ccc(Cl)nc12</smiles>

90<smiles>[R]Nc1ccnc2ccc(OC)nc12</smiles>

91<smiles>[R10]Nc1ccc2nccc([R])c2n1</smiles>

92

Figure 3. Compounds obtained by amination of halogenated 1,5-naphthyridine derivatives.

A one step synthesis of 1,5-naphthyridine-based DYRK1A inhibitors consisted in the $\mathrm{S}_{\mathrm{N}} \mathrm{Ar}$ reaction of the 1,5-naphthyridine core by means of a variety of elaborated amines for introducing amino substituents at the four-position (90, Figure 3) [21]. Likewise, a series of 2,8-disubstituted-1,5-naphthyridine analogues were synthesized and evaluated for in vitro antiplasmodial activity, as inhibitors of Plasmodium protein kinases (PKs). The brominated key intermediate was subjected to nucleophilic aromatic substitution using commercially available amines, respectively, in the presence of $\mathrm{Cs}_{2} \mathrm{CO}_{3}$ at $110{ }^{\circ} \mathrm{C}$ to give the corresponding derivatives 91 and 92 (Figure 3) [35].

Some additional nucleophilic amination reactions with replacement of leaving groups other than halogens were also performed. Triflate and tosyl groups were substituted by nucleophilic amines to yield the corresponding functionalized 1,5-naphthyridine compounds 93 and 95 (Scheme 33) [53].

2-Amino-1,5-naphthyridine derivatives 98 were obtained via Buchwald-Hartwig amination of 96 with the corresponding amines 97 by means of a palladium catalysed incorporation of the amine into the heterocyclic ring of 96 and in the presence of a phosphorated ligand, such as XantPhos (Scheme 34) [38]. Similar Buchwald couplings were used to synthesize other 2,8-disubstituted-1,5-naphthyridine 
analogues [35], and also compounds featuring a naphthyridine or cyano-naphthyridine segment as the electron acceptor and an acridine unit as the electron donor $[34,66]$.<smiles>[R16]CNC12CCC(CCc3c([X])cnc4ccc(O)nc34)(CC1)OC2</smiles>

60

$\mathrm{X}=\mathrm{F}, \mathrm{CN}$

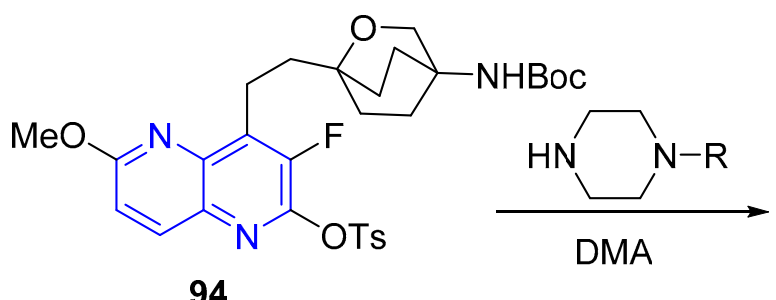<smiles>[R]Nc1ccc2ncc([X])c(CCC34CCC(NCCCC)(CO3)C4)c2n1</smiles>

93

$\mathrm{R}=\mathrm{PMB},\left(\mathrm{CH}_{2} \mathrm{CH}_{2}\right)_{2} \mathrm{O}$,

$\left(\mathrm{CH}_{2} \mathrm{CH}_{2}\right)_{2} \mathrm{SO}_{2}, \mathrm{Me}_{2}$<smiles>[R]N1CCN(c2nc3ccc(OC)nc3c(CCC34CCC(NCCC)(CC3)CO4)c2F)CC1</smiles>

$\mathrm{R}=\mathrm{CH}_{3}, \mathrm{Cbz}$

Scheme 33. Nucleophilic amination of triflate and tosyl substituted 1,5-naphthyridines.<smiles>Fc1ccc2nc(Cl)ccc2n1</smiles>

96

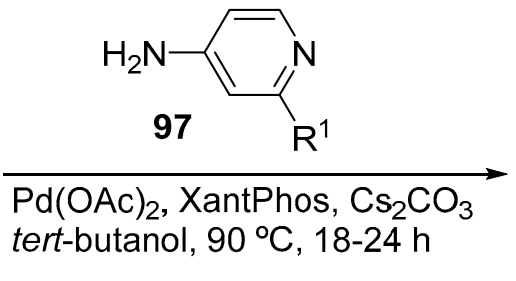<smiles>[R]c1cc(Nc2ccc3nc(F)ccc3n2)ccn1</smiles>

Scheme 34. Palladium catalyzed amination of 2-chloro-1,5-naphthyridines.

Likewise, the preparation of amino-1,5-naphthyridines may involve the coupling of tetrahydropyran-amide $\mathbf{9 9}$ with the bromo compound $\mathbf{7 3}$ (previously prepared, vide supra, Scheme 28) catalyst by palladium in the presence of $(R)-(+)-2,2^{\prime}-b i s$ (diphenylphosphino)-1,1'-binaphthalene (BINAP) to form the amide-containing derivative 100 (Scheme 35) [65].

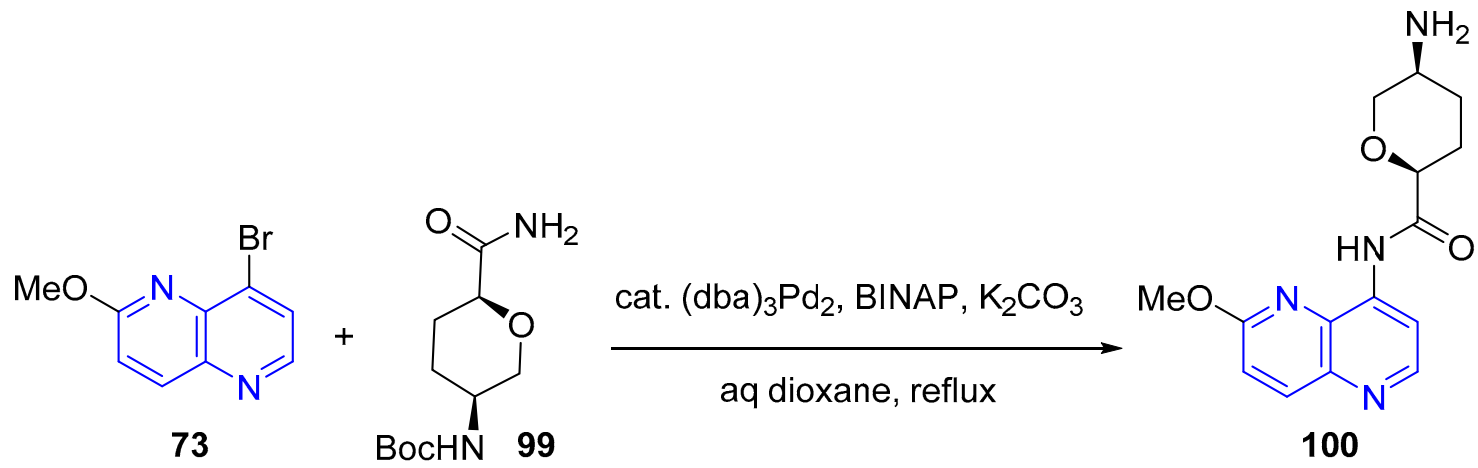

Scheme 35. Cross-coupling amination of 4-bromo-1,5-naphthyridine.

(b) Alcoxylation, Phenoxylation

In the study to find new methodologies for the preparation of fluorinated intermediates, some methoxylated derivatives/precursors 52 (previously prepared, vide supra, Scheme 15) were 
synthesized from 1,5-naphthyridine 74 through a $S_{N}$ Ar replacing the chloride with sodium methoxide (Scheme 36) [26]. This process has also been reported to obtain the derivative 101 by a nucleophilic displacement of fluorine with sodium methoxide in methanol under heating conditions (Scheme 36) [36].

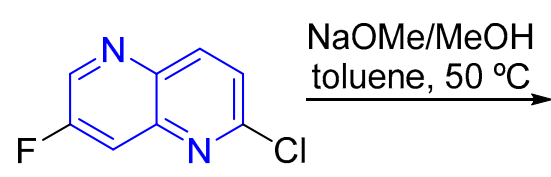

74<smiles>COc1ccc2ncc(F)cc2n1</smiles>

52<smiles>COc1cnc2ccc(=O)n(CCO)c2c1</smiles>

101

Scheme 36. Methoxylation of chloro-1,5-naphthyridines.

The synthesis of dialdehyde 103 (Scheme 37) was realized by the Ullman's reaction between vanillin 102 and 2,6-dibromo-1,5-naphthyridine 76 (previously prepared, vide supra, Figure 1) in DMSO at $80{ }^{\circ} \mathrm{C}$. In this case, using picolinic acid and copper(I) iodide as catalysts, the expected dialdehyde 103 was obtatined in $86 \%$ yield $[67,68]$.<smiles>COc1cc(C=O)ccc1Oc1ccc2nc(Oc3ccc(C=O)cc3OC)ccc2n1</smiles>

Scheme 37. Diphenoxylation of dibromo-1,5-naphthyridines.

On the other hand, starting from a 8-hydroxyl 1,5-naphthyridine 53 (previously prepared, vide supra, Scheme 16) and tetrahydropyran 104, the derivative 105 was prepared using a Mitsunobu coupling reaction (Scheme 38) [65].<smiles>COc1ccc2nccc(O)c2n1</smiles>

53<smiles>CC(C)(C)OC(=O)N[C@H]1CC[C@@H](CO)OC1</smiles>

104<smiles>COc1ccc2nccc(OCC3CCC(NC(=O)OCc4ccccc4)CO3)c2n1</smiles>

Scheme 38. Mitsunobu coupling reaction for the synthesis of alkoxy-1,5-naphthyridine.

(c) Sulfurization

The synthesis of 1,5-naphthyridine functionalized indenyl and cyclopentadienyl ligands containing sulfur substituents has been carried out by treatment of chloro derivative 72a (previously prepared, vide supra, Scheme 27) with sodium methanethiol in the presence of $\mathrm{NaH}$ to furnish the methylsulfanyl derivative 106a (Scheme 39) [62]. Similarly, the nucleophilic substitution of 72a with led to 2-methylpropane-2-thiol 106b (Scheme 39) with a moderate yield. The nucleophilic substitution 
of the chloride precursor with 4-methoxybenzyl-mercaptan ( $p$-MBSH) yielded the corresponding sulfurilated intermediate 107 (Scheme 39) [34].<smiles>Clc1ccnc2cccnc12</smiles>

$72 a$

\section{$\underset{\mathrm{DMF}}{\stackrel{\mathrm{HSR} / \mathrm{NaH}}{\longrightarrow}}$}<smiles>[R]Sc1ccnc2cccnc12</smiles>

106 a $R=M e$

b $\mathrm{R}={ }^{i} \mathrm{Bu}$<smiles>CC(=O)c1cnc2c(SO[14CH3])ccnc2c1</smiles>

107

Scheme 39. Sulfurization of 4-chloro-1,5-naphthyridines.

(d) Alkylation

The sulfoxide 1,5-naphthyridine derivative 108, obtained by oxidation of the corresponding sulphide, was reacted with $\mathrm{Li}$-indene ( $\mathrm{Li}$-Ind) at low temperature (Scheme 40 ). The reaction with Li-Ind led to an increased acidity of the indene so that the product was deprotonated in the reaction mixture, and afforded the corresponding indenyl-1,5-naphthyridine derivative 109 with C-C bond formation. Similarly, when the lithium 1,2,3,4-tetramethylcyclopentadienide ( $\mathrm{Li}-\mathrm{CpMe}$ ) was used the cyclopentadienyl-1,5-naphthyridine derivative 110 was obtained (Scheme 40) [62].<smiles>C[As](=O)c1ccnc2cccnc12</smiles>

108 i) 2 equiv Li-CpMe ${ }_{4} / \mathrm{Li}-$ Ind or 1.3 equiv Li-2-Melnd

ii) $\mathrm{H} \oplus$<smiles>C1=C(c2ccnc3cccnc23)c2ccccc2C1</smiles>

109<smiles>CC1=C(C)C(C)C(c2ccnc3cccnc23)=C1C</smiles>

110

Scheme 40. C-C bond formation for the preparation of 4-substituted-1,5-naphthyridines.

\subsection{Oxidations and Reductions}

\subsubsection{Oxidation}

(a) Aromatization of tetrahydro-1,5-naphthyridines

Tetrahydro- and decahydro-1,5-naphthtyrines can be easily oxidized to the aromatic 1,5naphthyridines. The oxidation of 1,2,3,4-tetrahydro-1,5-naphthyridines 111 may afford 1,5-naphthyridines 112 at high temperatures (Scheme 41). As examples, selenium at $320{ }^{\circ} \mathrm{C}$ or TIPB at $232{ }^{\circ} \mathrm{C}$ was heated with the tetrahydroquinoline 111 to prepare 1,5-naphthyridines 112 [69]. High temperatures with benzoquinone (BQ), molecular sulfur or 2,3-dichloro-5,6-dicyano- $p$-benzoquinone (DDQ) were also used to prepare the corresponding 1,5-naphthyridines by the oxidation of the corresponding tetrahydronaphthyridines [45].

An acceptorless dehydrogenation of 1,5-naphthyridine 113 by merging visible-light photoredox catalysis and cobalt catalysis at ambient temperature was achieved by using Ru-(bpy) ${ }_{3} \mathrm{Cl}_{2} \cdot 6 \mathrm{H}_{2} \mathrm{O}$ as a photosensitizer and $\mathrm{Co}(\mathrm{dmgH})_{2} \mathrm{PyCl}$ as a catalyst under optimized reaction conditions (Scheme 42). Aromatic 1,5-naphthyridine 114 was obtained in good yields [70]. A more general methodology is base on homogeneous catalysis using the iridium complexes with a functional bipyridonate ligand for the perdehydrogenation of bicyclic $N$-heterocycles (Scheme 42). Thus, aromatic 2,6-dimethyl-1,5-naphthyridine 114 was efficiently synthesized by this methodology (Scheme 42) [71]. 
<smiles>[R]c1cc2c(nc1[R])C([R])CC([R])N2</smiles>

111
Oxidation conditions:
a) $\mathrm{Se} 320^{\circ} \mathrm{C}$
b) TIPB $232^{\circ} \mathrm{C}$
c) $B Q$ dioxane, $100^{\circ} \mathrm{C}$
d) DDQ MW $150 \mathrm{~W} 25^{\circ} \mathrm{C}$
e) $\mathrm{S}_{8} 200^{\circ} \mathrm{C}$
f) $\mathrm{DDQ}$ (2 equiv)<smiles>[R]c1cc([R])c2nc([R])c([R])cc2n1</smiles>

112

Scheme 41. Oxidation of tetrahydro-1,5-naphthyridines to 1,5-naphthyridines.

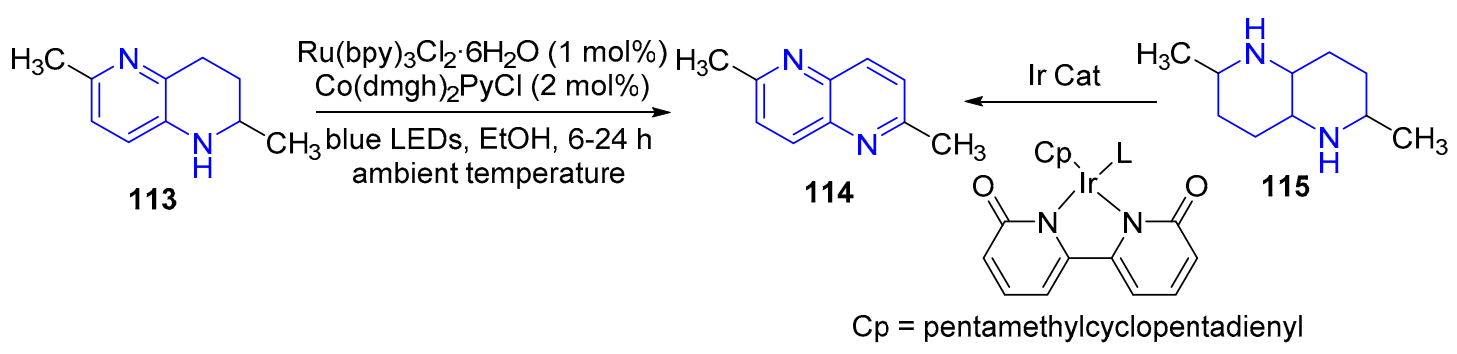

Scheme 42. Metal-mediated aromatization of tetra- and octahydro-1,5-naphthyridines.

(b) Preparation of 1,5-Naphthyridine N-oxides and Their Synthetic Application

$\mathrm{N}$-oxides $\mathbf{1 1 6}$ were easily prepared from differently substituted 1,5-naphthyridines $\mathbf{2 a} \mathbf{a} \mathbf{2} \mathbf{b}$ (previously prepared, vide supra, Scheme 1), 82a (previously prepared, vide supra, Scheme 30) and 117 (Scheme 43). In this way, standard reaction conditions (3-chloroperbenzoic acid, m-CPBA) to obtain the corresponding $N$-oxides $106 \mathbf{b}-\mathbf{d}$ were used to synthesize valuable intermediates for the construction of biologically active molecules [9,10,53]. Alternatively, 1,5-naphthyridines 2a (previously prepared, vide supra, Scheme 1) were transformed to the corresponding $\mathrm{N}$-oxide 118, at high conversion yields, by a monooxygenase PmlABCDEF recombinantly expressed in Escherichia coli as biocatalyst (Scheme 43). The optimized whole cell bioconversions produced a controllable, productive, and green method for the synthesis of 1,5-naphthyridine $N$-oxides. The approach proved to be chemoselective since it was used for the molecules bearing oxidation-sensitive functional groups. Also, this method provides regioselectivity as only specific mono $\mathrm{N}$-oxides were formed [72].

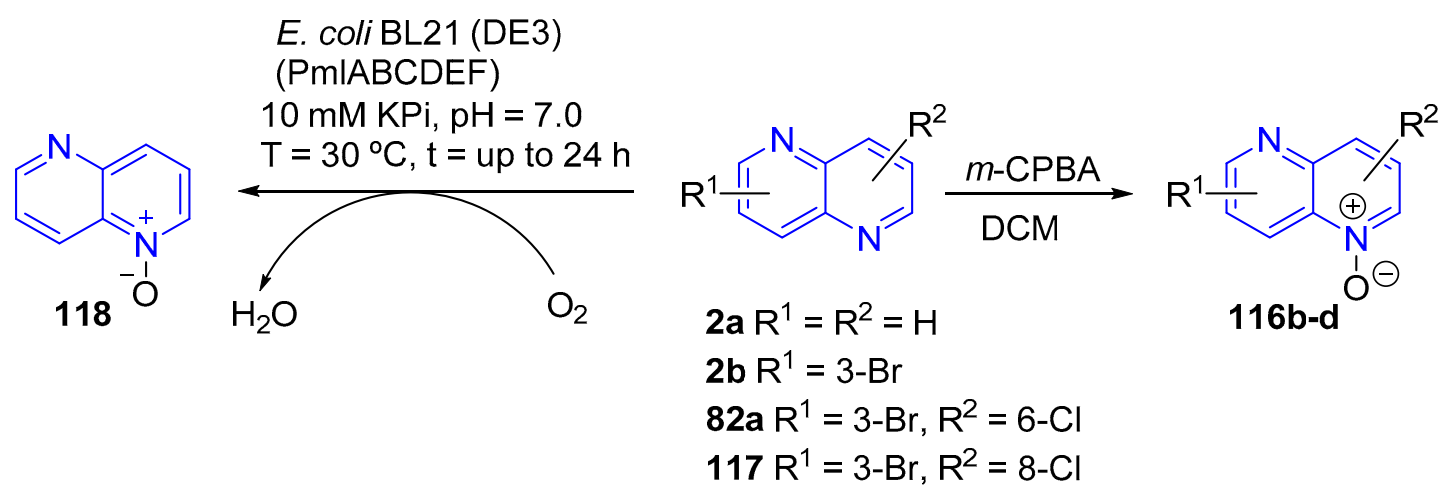

Scheme 43. N-Oxidation of 1,5-naphthyridines.

Then, after the formation of these $N$-oxides, they would serve for both electrophilic and nucleophilic addition to the 2- and 4-positions. 
Thus, the reaction of commercial 1,5-naphthyridine 2a (previously prepared, vide supra, Scheme 1) with $\mathrm{POCl}_{3}$, in the presence of a peracid such as $m$-CPBA, was used by Nishimura et al. to obtain a mixture of chlorinated 1,5-naphthyridine 71a (previously prepared, vide supra, Scheme 26) and 72a (previously prepared, vide supra, Scheme 27), through the formation of N-oxides 118 (Scheme 44) [73]. On the other hand, when starting from the di-N-oxide 119 derivative the corresponding dichloro 1,5-naphthyridine $\mathbf{1 2 0}$ was obtained [74].

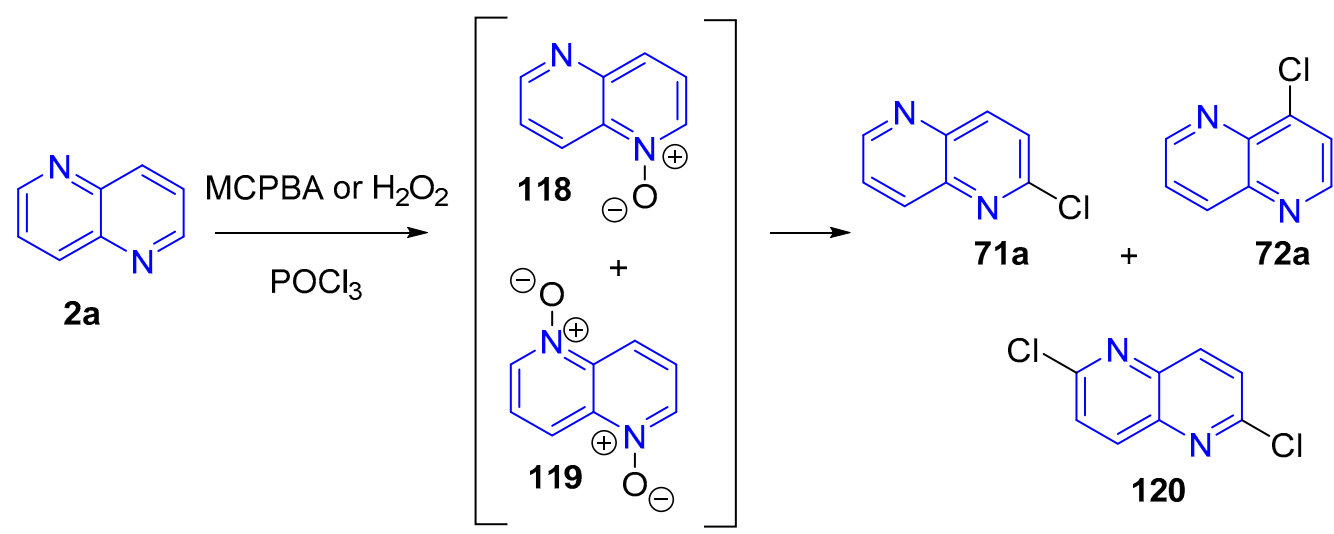

Scheme 44. Chlorination of 1,5-naphthyridines by $N$-oxides mediation.

Another application of mono $N$-oxide or di- $N$-oxide derivatives involved the preparation of 2-cyano heterocyclic scaffolds. From $N$-oxides 118 or 119 (previously prepared, vide supra, Scheme 44), after treatment with either tetramethylsilylcyanide (TMSCN) or potassium cyanide, the 2-cyano 121a or 2,6-dicyano $\mathbf{1 2 1 b}$ derivatives were respectively obtained (Scheme 45) [74]. In addition, conventional heating at $130{ }^{\circ} \mathrm{C}$ for $1 \mathrm{~h}$ of mono $\mathrm{N}$-oxide with TMSCN or under microwave conditions (power $50 \mathrm{~W}$ ) at $130^{\circ} \mathrm{C}$ for $5 \mathrm{~min}$ led to the compound 121a in good yield [75].<smiles>[O-][n+]1cccc2ncccc21</smiles><smiles>C[R15](=O)[O-]</smiles><smiles>[R]c1ccc2nc(C#N)ccc2n1</smiles><smiles>[O-][n+]1cccc2c1ccc[n+]2[O-]</smiles>

Scheme 45. Cyanation of $N$-oxides.

And for the preparation of 2-tosyl substituted naphthyridines, the nucleophilic substitution with TsCl over N-oxide 122 allowed the formation of compound 94 (previously prepared, vide supra, Scheme 33) ready for further nucleophilic substitution (Scheme 46) [53]. In some cases, when water and $\mathrm{K}_{2} \mathrm{CO}_{3}$ was used as base, the 1,5-naphthyridin-2(1H)-ones were obtained [9].<smiles>COc1ccc2c(n1)c(CCC13CCC(NC(=O)OCc4ccccc4)(CC1)CO3)c(F)c[n+]2[O-]</smiles><smiles>COc1ccc2nc([O-])c(F)c(CCC34CCC(NC(=O)O)(CC3)CO4)c2n1</smiles>

Scheme 46. Tosylation of $N$-oxide. 


\subsubsection{Reduction}

Homogeneous hydrogenation of arenes is a challenging transformation because of the stability derived from the aromaticity. In the particular case of $\mathrm{N}$-heteroarenes, this process has to overcome, not only the resonance stability, but also the possible poisoning of the catalyst by either the starting material or the product. Nevertheless, significant developments took place in the past decades and many applications are known for the hydrogenation of model $N$-heterocycles.

In this context, quenched skeletal $\mathrm{Ni}(\mathrm{QS} \mathrm{Ni})$ is an active and selective catalyst for predicable, controllable and selective partial hydrogenation of polycyclic aromatic hydrocarbons (PAHs). When heteroatoms substituted on the skeleton of the PAHs, the hydrogenation reaction would only occur at the substituted ring caused by the strong coordination ability of heteroatoms ( $i$, Scheme 47) [76]. Hydrogenation using hydrogen as reductant and cobalt catalysts such as oxide/cobalt nanoparticles featuring nitrogen-doped graphene layers on alumina $\left(\mathrm{Co}_{3} \mathrm{O}_{4}-\mathrm{Co} / \mathrm{NGr} @ \alpha-\mathrm{Al}_{2} \mathrm{O}_{3}\right)$ [77], or an aminobis(phosphine) $[\mathrm{PN}(\mathrm{H}) \mathrm{P}]$ pincer ligand coordinates to cobalt (Catalyst 1, Figure 4) [78], have been performed and 1,2,3,4-tetrahydro-1,5-naphthyridine 123 was obtained (ii-iii, Scheme 47; Figure 4). Transfer hydrogenation of $N$-heteroarenes has been firstly accomplished through homogeneous non-noble metal-catalysis. The combination of $\mathrm{Co}\left(\mathrm{BF}_{4}\right)_{2} \cdot 6 \mathrm{H}_{2} \mathrm{O}$ with tris(2-(diphenylphosphino)-phenyl)phosphine L1 (Figure 4) is able to reduce 1,5-naphthyridines in the presence of other sensitive functional groups, under mild conditions, using formic acid as a hydrogen source (iv, Scheme 47) [79].

In the presence of $\mathrm{KO}^{t} \mathrm{Bu}, N$-heterocyclic carbene-supported half-sandwich complex [Cp(IPr)Ru(pyr)2]-[PF6] (Catalyst 2, Figure 4) catalyzes transfer hydrogenation of $N$-heterocycles in isopropanol at the catalyst loading of $0.5 \mathrm{~mol} \%$. Under these conditions, 1,5-naphthyridine 2a (previously prepared, vide supra, Scheme 1) could be hydrogenated in good yields (v, Scheme 47; Figure 4) [80]. In another approach, the transfer hydrogenation of 1,5-naphthyridines could be accomplished in good yields, using ruthenium(II) complexes (Catalyst 3) supported by a pyrazole-phosphine ligand (vi, Scheme 47, Figure 4) [81].

A Pd-catalyzed transfer hydrogenation of various $N$-heteroaromatic compounds with bis(pinacolato)diboron (B2pin2), as a mediator in environmentally benign water as both solvent and hydrogen donor has been disclosed. This reaction proceeded under ambient temperature and 1,5-naphthyridine $\mathbf{2 a}$ (previously prepared, vide supra, Scheme 1) underwent selective hydrogenation in one of the pyridine rings (vii, Scheme 47) [82].<smiles></smiles>
i) QS Ni/ $\mathrm{H}_{2}(1.5 \mathrm{MPa}) / \mathrm{THF}$
ii) $\mathrm{Co}_{3} \mathrm{O}_{4}-\mathrm{Co} / \mathrm{NGr} @ \mathrm{a}-\mathrm{Al}_{2} \mathrm{O}_{3}(4 \mathrm{~mol} \%) / \mathrm{H}_{2}(2 \mathrm{MPa}) /$ toluene, $120^{\circ} \mathrm{C}, 48 \mathrm{~h}$
iii) Co-catalyst1 $(10 \mathrm{~mol} \%) / \mathrm{H}_{2}(20 \mathrm{~atm}) / \mathrm{THF}, 150^{\circ} \mathrm{C}$
iv) $\mathrm{Co}\left(\mathrm{BF}_{4}\right)_{2} \cdot 6 \mathrm{H}_{2} \mathrm{O}(5 \mathrm{~mol} \%) \mathrm{L} 1$ (M:L/1:1), $\mathrm{HCO}_{2} \mathrm{H}$ (10 equiv) $100^{\circ} \mathrm{C} / \mathrm{PrOH}$
v) Ru-catalyst $2(0.5 \mathrm{~mol} \%), 1,5 \% \mathrm{KO}^{t} \mathrm{Bu} / \mathrm{H}_{2} / \mathrm{PrOH}$
vi) Ru-catalyst 3 (1 mol\%), KO ${ }^{t} \mathrm{Bu}(10 \mathrm{~mol} \%)$, 2-propanol, $80^{\circ} \mathrm{C}, 24 \mathrm{~h}$
vii) $\mathrm{Pd}(\mathrm{OAc})_{2}$ (10 mol\%), $\mathrm{B}_{2} \mathrm{pin}_{2}$ (3 equiv), $\mathrm{H}_{2} \mathrm{O}(2 \mathrm{~mL}), \mathrm{N}_{2}$
viii) $\mathrm{HMPA}(20 \mathrm{~mol} \%), \mathrm{HSiCl}_{3}$ (6 equiv) $\mathrm{DCM}, 25^{\circ} \mathrm{C}$

Scheme 47. Selective reduction of 1,5-naphthyridine to 1,2,3,4-tetrahydro-1,5-naphthyridine. 
Catalyst 1

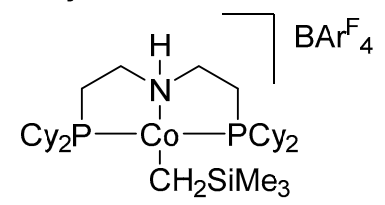

Cobalt Pincer Catalyst

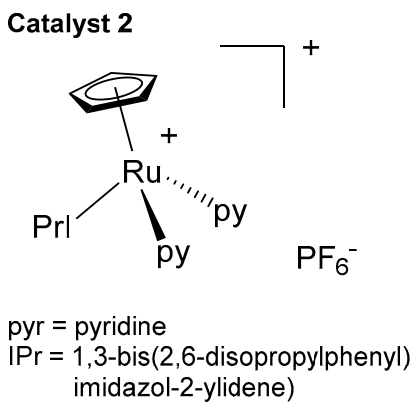<smiles>Pc1ccccc1P(c1ccccc1)c1c(P)cccc1P</smiles>

Catalyst 3

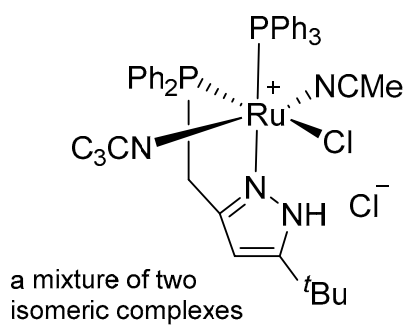

Figure 4. Catalyst and ligand structures.

A method for the hexamethylphosphoric triamide (HMPA)-catalyzed metal-free transfer hydrogenation of pyridines by using trichlorosilane hydride $\left(\mathrm{HSiCl}_{3}\right)$ has been developed. The suitability of this method for the reduction of other $N$-heteroarenes has also been demonstrated. Thirty-three different substrates have been reduced to designed products in $45-96 \%$ yields. 1,5-Naphthyridine 2a (previously prepared, vide supra, Scheme 1) could only be partially reduced to the corresponding tetrahydro derivative $\mathbf{1 2 3}$ (viii, Scheme 47) [83].

For the first time, Mn catalyzed transfer hydrogenation of aromatic $N$-heterocycles, which normally involve precious metal catalysts such as $\mathrm{Ru}$, $\mathrm{Rh}$ and Ir complexes, has been reported for 1,5-naphthyridine to give the tetrahydro derivative 123 (previously prepared, vide supra, Scheme 47) in the presence of $\mathrm{KO}^{t} \mathrm{Bu} / \mathrm{PrOH}$ (Scheme 48) in excellent yield. Furthermore, deuterium labeling experiments using 1,5-naphthyridine has been performed. Interestingly, when 2-propanol-2- $d_{1} \mathbf{1 2 4}$ was used as the solvent and hydrogen source, selective incorporation of deuterium was observed at the 2- and 4-positions, corresponding to incorporation of one D-atom to each of the $\mathrm{CH}_{2}$ groups (i.e., $50 \%$ deuteration at each of the methylene positions), while the 3-position did not contain $\mathrm{D}$ atom at detectable levels (Scheme 48). Contrarily, when 2-propanol-OD 125 was used, no deuterium was detected in 2- and 4-positions, and some deuterium was detected only in the 3-position (ca. $14 \% \mathrm{D}$ incorporation in the $\mathrm{CH}_{2}$ group, Scheme 48) [84].<smiles>c1cnc2cccnc2c1</smiles>

$2 a$

$$
\begin{aligned}
& \stackrel{\mathrm{LMn}(\mathrm{CO})_{3} \mathrm{Br}}{(5 \mathrm{~mol} \%)} \\
& \underset{\mathrm{KO}}{\mathrm{K}} \mathrm{Bu}(15 \mathrm{~mol} \%)
\end{aligned}
$$

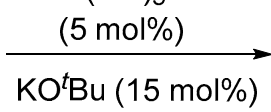

HO'Pr, $80^{\circ} \mathrm{C}$

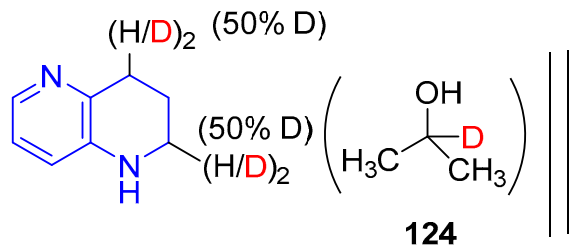<smiles>c1cnc2c(c1)NCCC2</smiles>

123

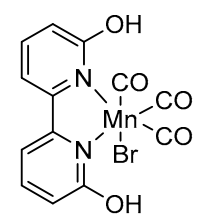

$\operatorname{LMn}(\mathrm{CO})_{3} \mathrm{Br}$

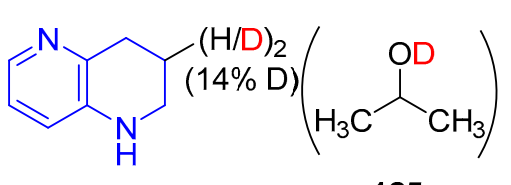

125

Scheme 48. Hydrogen/deuterium exchange in selective reduction processes. 
Recently, a chemoselective reduction of 1,5-naphthyridine 2a (previously prepared, vide supra, Scheme 1) by molecular hydrogen has been described under very mild reaction conditions using a simple Mn(II) complex, manganese pentacarbonyl bromide (Scheme 49) [85].

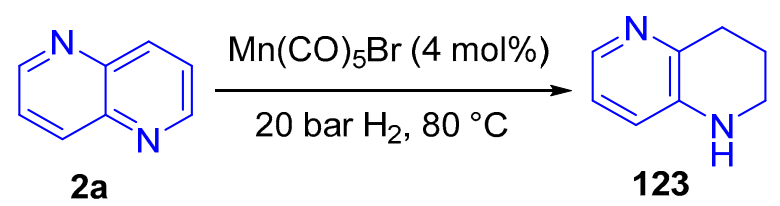

Scheme 49. Manganese catalyzed reduction of 1,5-naphthyridine.

In contrast, $\mathrm{H} / \mathrm{D}$ exchange reactions in $\mathrm{N}$-heterocyclic substrates have received much less attention. It was found that modification of the original catalyst by using the isolobal relationship between $N$-heterocyclic carbenes (NHCs) and phosphines affords a new catalytic system capable of H/D exchange in $N$-heterocyclic substrates under very mild conditions and at low catalyst loading. NHC-supported hydride complexes of ruthenium ( $\mathrm{Cp}(\mathrm{IMes}) \mathrm{RuH}_{3}$ ) showed excellent catalytic activity in the H/D exchange of $\mathrm{N}$-heterocyclic compounds under mild conditions and low catalyst loading (Scheme 50) [86].<smiles>CC(C)(C)c1ccc2ncccc2n1</smiles>

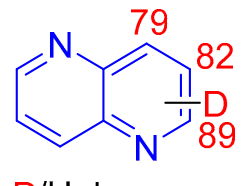

$\mathrm{D} / \mathrm{H}$ degree

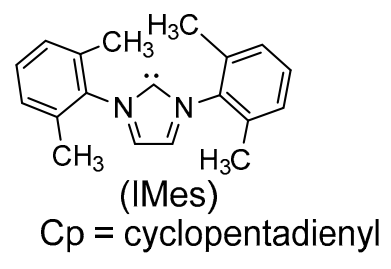

Scheme 50. Hydrogen/deuterium exchange processes by using ruthenium catalyst.

Nitrogen modified heterogeneous cobalt catalysts supported on carbon were prepared in water using inexpensive melamine or melamine resins as nitrogen source. The optimal catalyst Co/Melamine-2@C-700 allows the selective transfer hydrogenation of diverse heteroarenes using formic acid as reductant (Scheme 51). Compared to most known transfer hydrogenations, the addition of base is not necessary to obtain sufficient catalyst activity. In speed of this, the reduction of 1,5-naphthyridines required a 2.5 equiv. of $\mathrm{Et}_{3} \mathrm{~N}$ and the corresponding formylated product $\mathbf{1 2 6}$ was obtained in a moderate yield (38\%) [87].<smiles>c1cnc2cccnc2c1</smiles>

$2 a$
Co/Melamine-2@C-700 $(10 \mathrm{~mol} \%)$

$\mathrm{HCOOH}(10$ equiv), toluene $130^{\circ} \mathrm{C}, 24-27 \mathrm{~h}$<smiles>O=CN1CCCc2ncccc21</smiles>

Scheme 51. Cobalt catalyzed reduction and $N$-formylation sequence of 1,5-naphthyridine.

The first enantioselective nucleophilic dearomatization of diazarenes using an anion-binding organocatalysis approach has been developed. Tetrakistriazole-based H-bond donor catalysts type A (Figure 5) were the best catalysts. In the case of 1,5-naphthyridine 2a (previously prepared, vide supra, Scheme 1), which has one nitrogen atom in each ring, the challenge was the control of the regioselectivity, since both the C-4 and C-2 positions of each heteroaromatic ring are prone to nucleophilic addition. A good regioselectivity of 95:5 was obtained in favor of the C-2-addition product 127 when 2,2,2-trichloroethyl chloroformate (trocCl) was used in the presence of methyl tert-butyl ether (MBTE) (Scheme 52). After the separation from the minor 4-addition product 128, the 2-addition compound 127 was obtained in 86\% yield and a good 83:17 enantiomeric ratio [88]. 


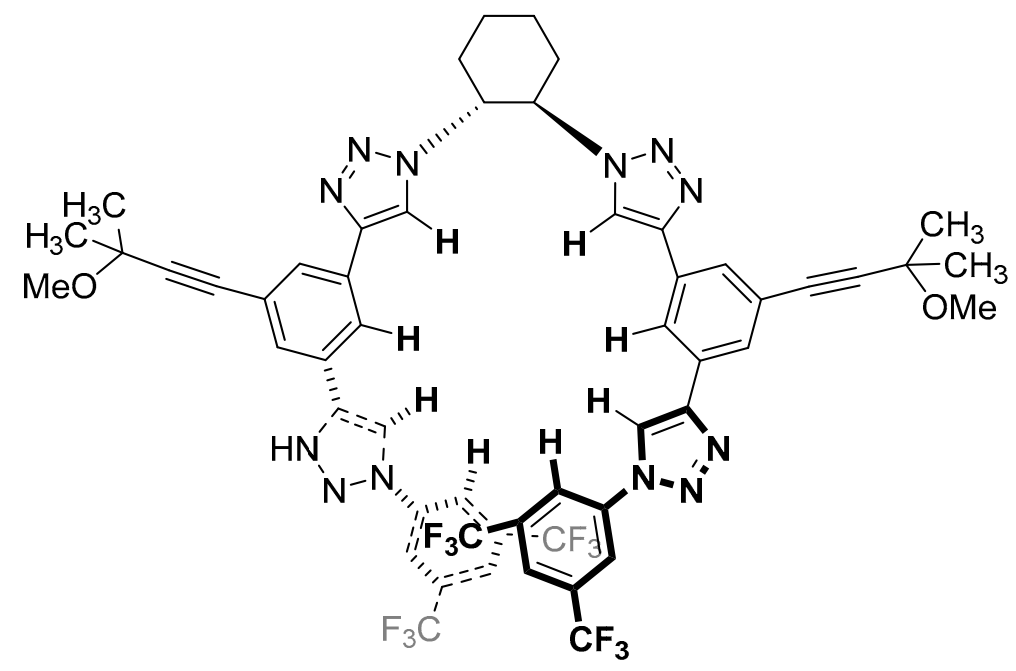

Figure 5. Catalyst A structure.

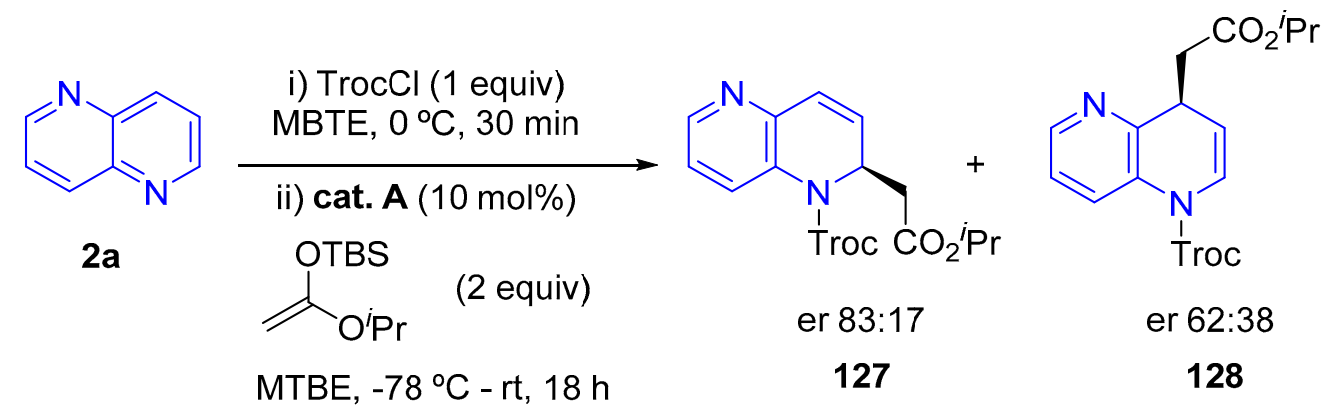

Scheme 52. Enantioselective preparation of dihydro-1,5-naphthyridines.

Selective reduction of one of the pyridine or both pyridine rings moieties of 1,5-naphthyridines can be achieved. Thus, 2,6-disubstituted 1,5-naphthyridines 114 (previously prepared, vide supra, Scheme 42) were asymmetrically hydrogenated catalyzed by chiral cationic ruthenium diamine complexes, with good to excellent enantioselectivities. A wide range of 1,5-naphthyridine derivatives were efficiently hydrogenated to give 1,2,3,4-tetrahydro-1,5-naphthyridines $\mathbf{1 2 9}$ with up to $99 \%$ ee and full conversions (Scheme 53). Subsequently, the optically pure (S)-129 was smoothly reduced using $\mathrm{PtO}_{2}$ as a catalyst to provide (2S,6S,9R,10R)-2,6-dimethyl-1,5-diaza-cis-decalin $\mathbf{1 3 0}$ in $87 \%$ yield as the sole product without other diastereomers (Scheme 53). In view of the unfavorable steric hindrance between the surface of the $\mathrm{PtO}_{2}$ catalyst and the methyl group in the 2-position, the opposite face of molecule is more inclined to approach the heterogeneous catalyst surface [89].

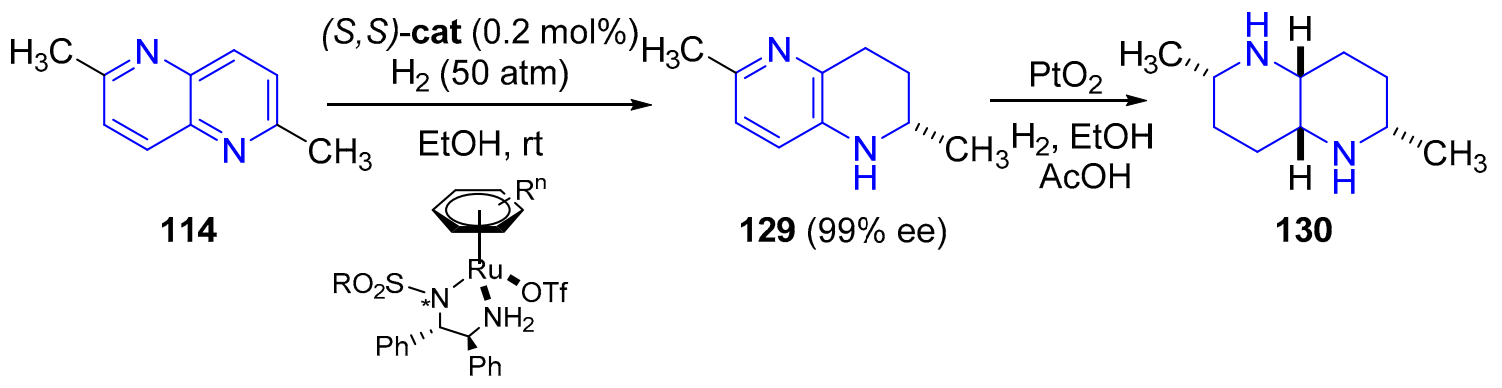

( $S, S)$-cat $R=T s$,

$\mathrm{R}^{\mathrm{n}}-\mathrm{Ar}=$ hexamethylbenzene

Scheme 53. Enatioselective reductions of 1,5-naphthyridines. 


\subsection{C-C Bond Constructions, Cross-Couplings}

The generation of metalated aromatics has become extremely important for the introduction of substituents, especially carbon substituents, by subsequent reaction with an electrophile.

In a study to find new methodologies for the late-stage introduction of fluorine into advanced intermediates, metal-halogen exchange was used to introduce a methyl group of the 1,5-naphthyrine 26 (previously prepared, vide supra, Scheme 8) leading to the methylated-1,5-naphthyridine 131 with good yield (Scheme 54) [26].<smiles>COc1ccc2ncc(F)c(Br)c2n1</smiles>

Scheme 54. Methylation of bromo-1,5-naphthyridine with organolithium reagent.

Knochel et al. reported an excellent and efficient set of regioselective metalations and functionalizations of the 1,5-naphthyridine scaffold using $\mathrm{Zn-}, \mathrm{Mg-}$, and tetramethylpiperidyl (Li-TMP) bases. It was possible to metalate the 1,5-naphthyridine scaffold regioselectively providing mono-, di-, tri-, or tetrasubstituted naphthyridines [90]. Thus, the precomplexation of type 1 naphthyridine with the magnesium amide $\mathrm{TMP}_{2} \mathrm{Mg} \cdot 2 \mathrm{LiCl}$ was found to induced a magnesiation at the C-4-position, which after quenching with several electrophiles $\left(E^{1}-X\right)$, led to 4-substituted 1,5-naphthyridines of type 2 (Scheme 55). The presence of a substituent E1 on C-4 of the naphthyridine type 2 prevented further complexation of a metallic amide at N5 and favored the precomplexation of $\mathrm{TMPMgCl} \cdot \mathrm{LiCl}$ or TMPZnCl$\cdot \mathrm{LiCl}$ at N1. This favored a directed magnesiation (or zincation) at C-8 providing, after quenching with several electrophiles $\left(\mathrm{E}^{2}-\mathrm{X}\right)$, the regioselectively defined 4,8-substituted 1,5-naphthyridines of type 3. Alternatively, the naphthyridines type 2 were treated with $\mathrm{BF}_{3} \cdot \mathrm{Et}_{2} \mathrm{O}_{\text {, }}$ which resulted in a regioselective magnesiation at C-2 using TMPMgCl-LiCl. After quenching with an electrophile ( $\left.E^{2}-X\right)$, 2,4-disubstituted 1,5-naphthyridines of type 4 were obtained (Scheme 55).<smiles>c1cnc2cccnc2c1</smiles>

type 1

(2a)

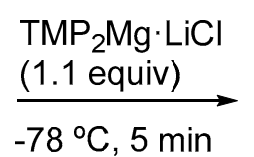

THF<smiles>[Al]c1ccnc2cccnc12</smiles>

1) $\mathrm{BF}_{3} \cdot \mathrm{OEt}_{2}$

2) $\mathrm{TMPMgCl} \cdot \mathrm{LiCl}$<smiles></smiles>

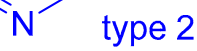

TMPZnCl.LiCl

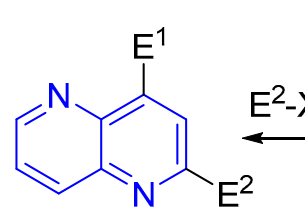

type 4
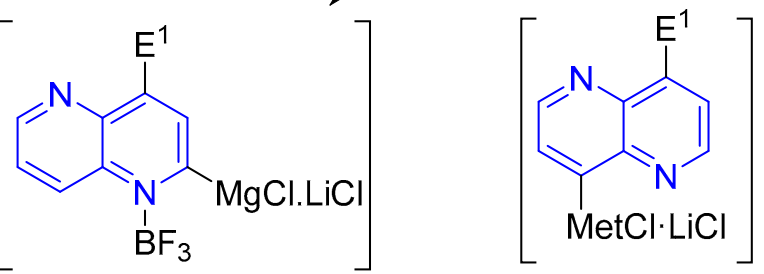

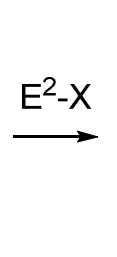<smiles>[Z7]c1ccnc2c([14F])ccnc12</smiles>

type 3

Scheme 55. Knochel difunctionalization of 1,5-naphthyridines mediated by organometallic reagents.

A third functionalization of 2,4-disubstituted 1,5-naphthyridines of type $4\left(\mathrm{E}^{1}=\mathrm{Ph}\right)$ with stronger lithium amide TMPLi readily coordinated to N1 and lithiated the closest C-H bond at C-8. The 8-lithionaphthyridine was trapped by several electrophiles to give 1,5-naphthyridine type 5 (Scheme 56). A fourth functionalization was achieved using a lithium mediated "halogen dance" 
rearrangement. Thus, the reaction of the trifunctionalized naphthyridine type 5 with TMPLi followed by quenching with water gave the corresponding regioisomer type 6 . The formation was explained by a lithiation at position 7 , leading to the lithium intermediate $\mathbf{A}$. The following very fast "halogen dance" provided the more stable C-8-lithiated naphthyridine $\mathbf{B}$. Reaction of $\mathbf{A}$ with various electrophiles $\left(\mathrm{E}^{4}-\mathrm{X}\right)$ gave the 2,4,7,8-tetrasubstituted 1,5-naphthyridines type 6 in good yields (Scheme 56).<smiles>CCc1cc(-c2ccccc2)c2ncccc2n1</smiles>

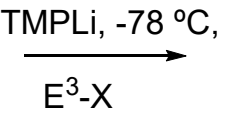

type 4<smiles>CCCCCCC</smiles><smiles></smiles><smiles>[Z7]c1cc(-c2ccccc2)c2nccc([B])c2n1</smiles>
type 5

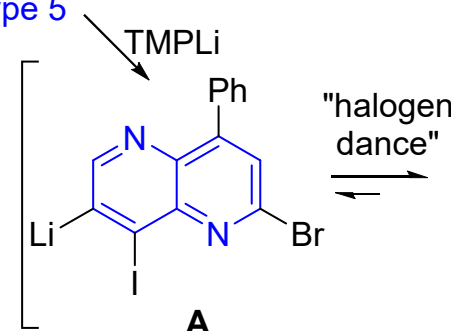

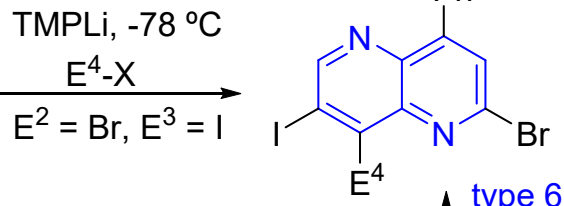

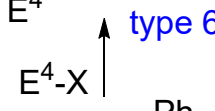<smiles>Cc1cc(Cl)c2nc(F)cc(-c3ccccc3)c2n1</smiles>

Scheme 56. Knochel functionalization of disubstituted 1,5-naphthyridines mediated by organometallic reagents.

Other metalation examples have been applied in the structure-activity relantionship (SAR) study of different linkers for the preparation of some active compounds. Nucleophilic addition of deprotonated 1,5-naphthyridine 52 (previously prepared, vide supra, Scheme 15) to aldehyde or ketone $\mathbf{1 3 2}$ after treatment with $n$-BuLi or lithium diisopropylamide (LDA) produced the corresponding alcohol 133 (Scheme 57) [91].<smiles>COc1ccc2ncc(F)cc2n1</smiles><smiles>[10BH2]</smiles>

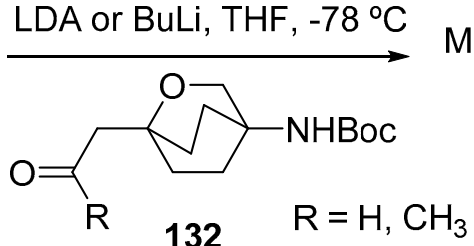<smiles>[R]C(O)(CC12CCC(NCCCC)(CC1)OC2)c1c(F)cnc2ccc(OC)nc12</smiles>

133

Scheme 57. Synthesis of alcohol derivatives from carbonyl compounds and metallated 1,5-naphthyridine.

Similarly, a general synthetic access to some 1,5-naphthyridines involved the reaction of bromo derivatives 73 (previously prepared, vide supra, Scheme 28) with $n$-butyl lithium at $-78^{\circ} \mathrm{C}$ generating the lithio anion that reacted with aldehyde $\mathbf{1 3 4}$ to yield benzylic alcohol $\mathbf{1 3 5}$ (Scheme 58), ready for further derivatization [65].

The 1,5-naphthyridine ring has been subjected to a wide variety of C-C bond forming cross-coupling reactions, such as Heck, Suzuki, Negishi, among others.

An expert opinion of a patent was given by Norman where 1,5-naphthyridines were prepared from commercially available 1,5-naphthyridine derivatives with $\mathrm{Et}_{2} \mathrm{Zn}$ in the presence of a palladium catalyst (Scheme 59). A novel C-C bond construction occurred in position 6 of the 1,5-naphthyridine ring. With this method 10 derivatives were synthesized [92]. 
<smiles>COc1ccc2nccc(C(O)CC3CCC(NC(=O)OCc4ccccc4)CO3)c2n1</smiles>

Scheme 58. Synthesis of secondary alcohol derivative from aldehyde and metallated 1,5-naphthyridine.<smiles>Clc1nc2cccnc2cc1-c1ccccc1</smiles>

136

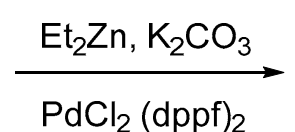

$\mathrm{PdCl}_{2}(\mathrm{dppf})_{2}$<smiles>CCc1nc2cccnc2cc1-c1ccccc1</smiles>

137

Scheme 59. Cross-coupling ethylation of 1,5-naphthyridine.

In order to prepare the 2,2'-bi-1,5-naphthyridine dimer 138, a new ambivergent ligand in metal complexes, a previously obtained 2-chloro-1,5-naphthyridine 71a (previously prepared, vide supra, Scheme 26) was dimerized by a new synthetic route which, included a $\mathrm{Ni}(0)$-catalysed coupling process (Scheme 60) [63].

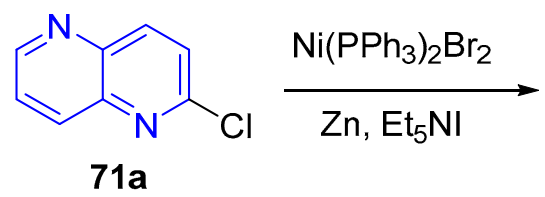<smiles>c1cnc2ccc(-c3ccc4ncccc4n3)nc2c1</smiles>

Scheme 60. Metal catalyzed dimerization of 1,5-naphthyridine.

Boronic acids have been widely used in Suzuki cross coupling reaction. This strategy favors the incorporation of alkyl and/or aryl groups in different positions of the 1,5-naphthyridine. Synthesis of 2-aryl-1,5-naphthyridine derivatives 141 , based on the cross-coupling reaction of commercially available 2-iodo-1,5-naphthyridine $\mathbf{1 3 9}$ with aromatic and heteroaromatic boronic acids $\mathbf{1 4 0}$ in the presence of $\mathrm{Pd}\left(\mathrm{PPh}_{3}\right)_{4}$, was reported (Scheme 61). Easily available starting materials, moderate reaction conditions, short reaction time, and higher yields of the products were the major advantages of this method [93]. A Suzuki coupling by using $\mathrm{CsCO}_{3}$ as base and $\mathrm{Pd}(\mathrm{dppf}) \mathrm{Cl}_{2}$ as catalyst was also completed for the preparation of 2-substituted 1,5-naphthyridines 142 (Scheme 61) [21].

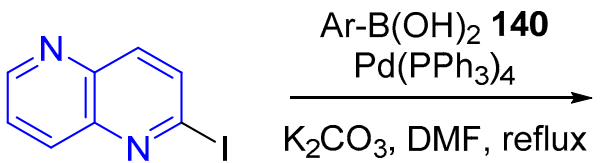

139<smiles>Brc1ccc2ncccc2n1</smiles>

141<smiles>[R4]Nc1c([R])cnc2ccc([Al])nc12</smiles>

142

Scheme 61. Suzuki cross-coupling reaction to obtain 2-aryl-1,5-naphthyridines.

Nishimura et al. prepared 2-aryl-1,5-naphthyridine derivative 144 based on the coupling reaction between boronic acid pinacol ester of functionalized 4-sulphonylamino pyridine 143, and chloro 
1,5-naphthyridine 71a (previously prepared, vide supra, Scheme 26) in the presence of Pd complexes (Scheme 62) [73].<smiles>CC1(C)OB(c2cnc(Cl)c(NS(=O)(=O)c3ccc(F)cc3)c2)OC1(C)C</smiles><smiles>CC(C)(C)c1cnc(Cl)c(NS(=O)(=O)c2ccc(F)cc2)c1</smiles>

Scheme 62. Suzuki cross-coupling reaction to obtain substituted 2-pyrido-1,5-naphthyridine.

A novel regioisomeric series of 3-aryl-1,5-naphthyridine derivatives $\mathbf{1 4 6}$ have been constructed by Galatsis et al. using a Suzuki cross coupling reaction (Scheme 63). The method involved 3-bromo-1,5-naphthyridine $\mathbf{2 b}$ (previously prepared, vide supra, Scheme 1) and boronic acid $\mathbf{1 4 5}$ with palladium as catalyst to give derivatives 146 [94].
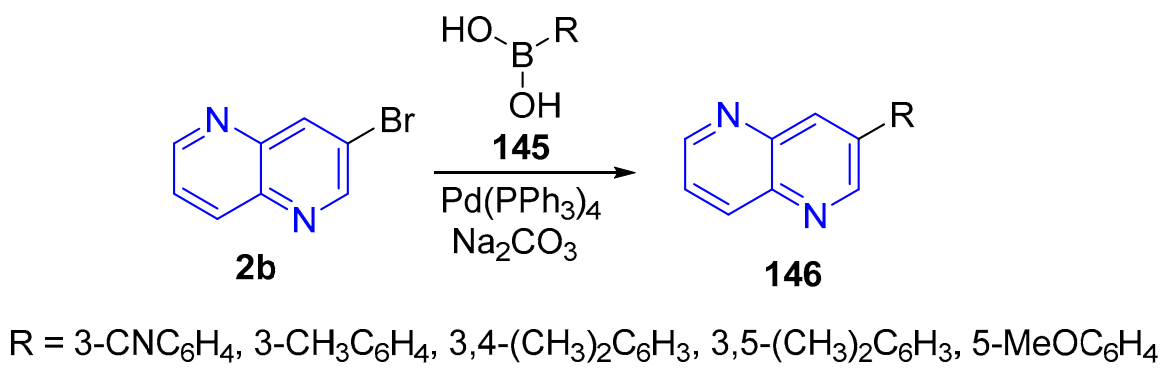

Scheme 63. Cross-coupling reaction to obtain 3-aryl-1,5-naphthyridines.

For example, during the synthesis of (7-aryl-1,5-naphthyridin-2-yl)ureas $\mathbf{1 4 9}$ aromatic moieties were introduced at position 7 of compound 147 under a palladium-catalyzed Suzuki-Miyaura type reaction, using boronic acids or esters 148 . The target compounds 149 were obtained in low to good yields (Scheme 64) [10].<smiles>[R]NC(=O)Nc1ccc2ncc(Br)cc2n1</smiles>

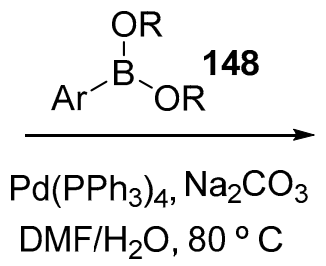<smiles>[R]NC(=O)Nc1ccc2ncc([Al])cc2n1</smiles>

Scheme 64. Cross-coupling reaction to obtain 7-aryl-1,5-naphthyridines.

Another example can be found for the synthesis of some novel 1,5-naphthyridine derivatives 152, which were prepared in $83 \%$ yield by Suzuki reaction under the catalysis of $\mathrm{Pd}\left(\mathrm{PPh}_{3}\right)_{4}$ with $\mathrm{Cs}_{2} \mathrm{CO}_{3}$ as the alkali (Scheme 65) [9].

A Suzuki-Miyaura protocol was used to combine 4-formylarylboronic acid 154, $\mathrm{Pd}(\mathrm{dppf}) \mathrm{Cl}_{2}$ as catalyst and $\mathrm{K}_{2} \mathrm{CO}_{3}$ as a base with a previously prepared 8-bromo-1,5-naphthyridine 153 in order to prepare the 8-(4-formylaryl)-2-methoxynaphthyridine $\mathbf{1 5 5}$ in high yield (Scheme 66) [95]. The Suzuki coupling of 8-substituted-1,5-naphthyridine alkenes $\mathbf{1 5 6}$ started from bromides with trans-phenylvinyl boronic acid under the catalysis of $\mathrm{Pd}\left(\mathrm{PPh}_{3}\right)_{4}$ giving rise to the respective phenyl alkenes (Scheme 66) [65]. 
<smiles>Cn1cc(-c2cnc3ccc(=O)[nH]c3c2)cn1</smiles>

Scheme 65. Suzuki reaction to obtain 7-pyrazolyl-1,5-naphthyridinone.<smiles>CCOC(=O)c1cnc2ccc(OCC)nc2c1Br</smiles><smiles>CCOC(=O)c1cnc2ccc(OC)nc2c1-c1ccc(C=O)cc1F</smiles><smiles>[R]c1cnc2ccc(OC)nc2c1/C=C/Pc1ccccc1</smiles>

Scheme 66. Cross-coupling reaction for the preparation of 8-substituted-1,5-naphthyridines.

The hydroboration of vinyl oxabicyclooctane 157 followed by Suzuki coupling with 8-bromo1,5-naphthyridine 26 (previously prepared, vide supra, Scheme 8), mediated by $\mathrm{Pd}\left(\mathrm{PPh}_{3}\right)_{4}$, and $\mathrm{K}_{3} \mathrm{PO}_{4}$ allowed the formation of the functionalized heterocycle 158 (Scheme 67) [25,53]. Similarly, hydroboration of the corresponding alkene with 9-borabicyclo(3.3.1)nonane (9-BBN) followed by Suzuki coupling in the presence of $\mathrm{Pd}(\mathrm{dppf}) \mathrm{Cl}_{2}$ as catalyst and $\mathrm{Cs}_{2} \mathrm{CO}_{3}$ as base afforded the corresponding dioxane-linked derivatives 159, ready for further transformation (Scheme 67) [96].

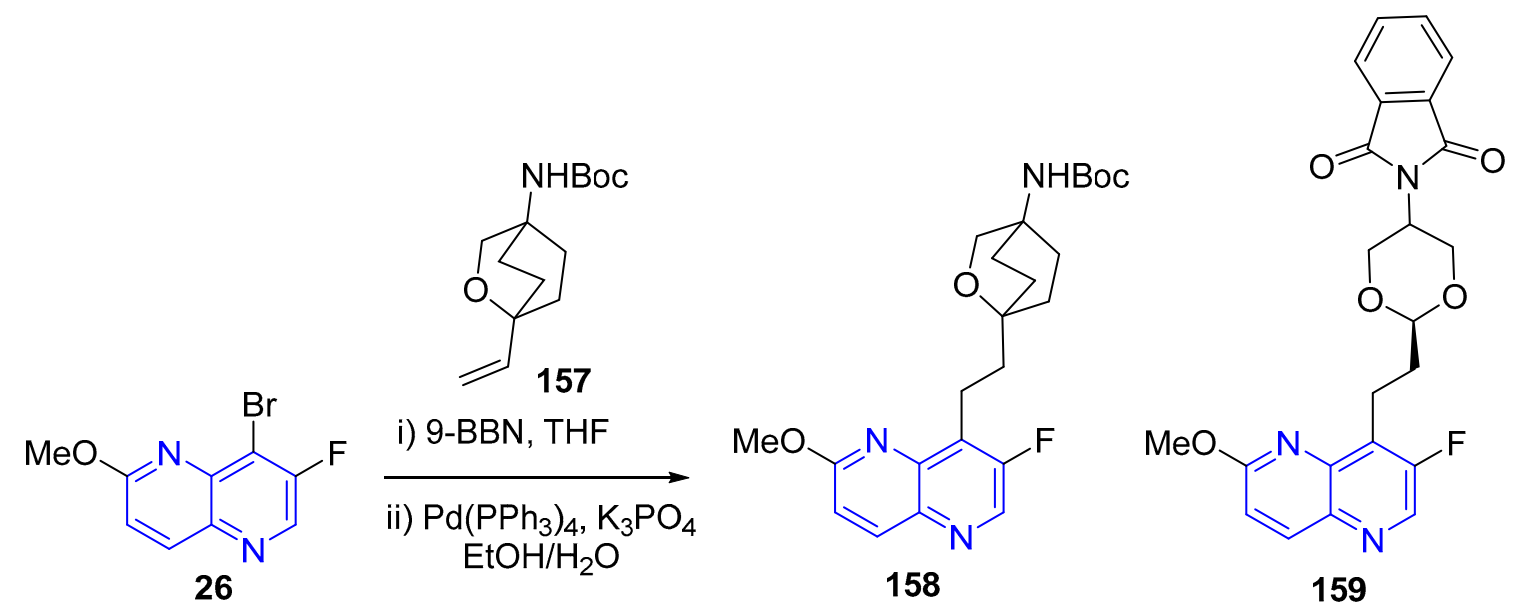

Scheme 67. Suzuki reaction for the synthesis of functionalized 1,5-naphthyridines.

This strategy was also used for the double incorporation of alkyl or aryl groups into the skeleton of 1,5-naphthyridines. The last step to obtain the 2,6-bis(4-(9,9-dimethylacridinyl)phenyl)-1,5-naphthyridine 161 was a Suzuki-Miyaura coupling between the chlorinated 2,6-naphthyridine 120 (previously prepared, vide supra, Scheme 44) and (4-(9,9-dimethylacridin10(9H)-yl)phenyl) boronic acid 160 (Scheme 68) [40]. 


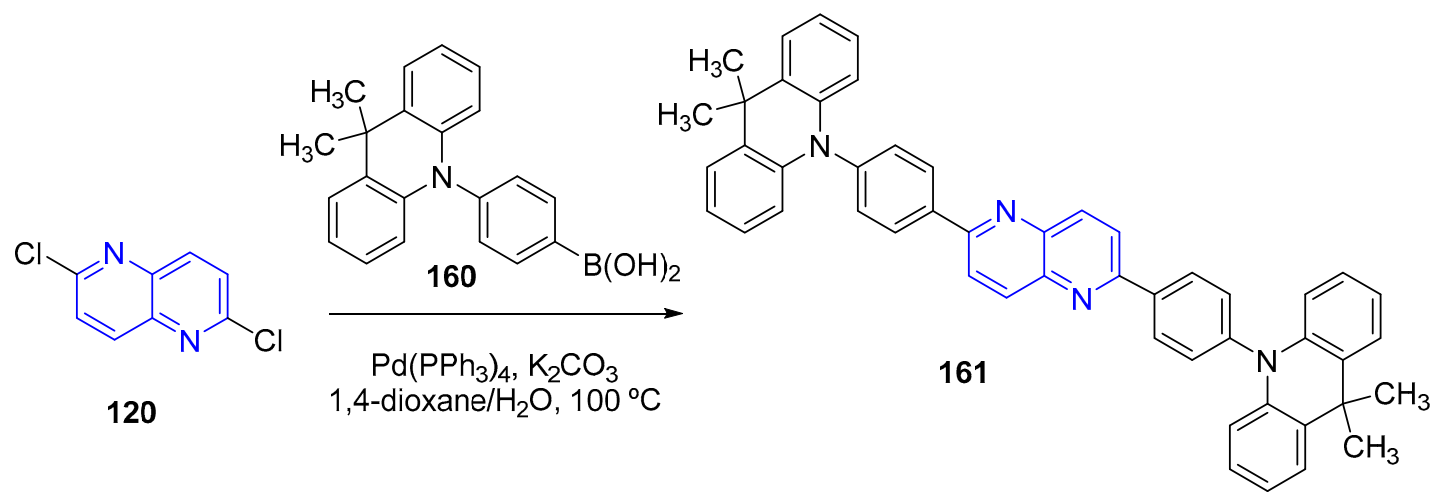

Scheme 68. Difunctionalization of 1,5-naphthyridine by Suzuki reactions.

In a similar way, the synthesis of poly [1,5-naphthyridine-(3-hexylthiophene)] semi-conducting polymer 163 has been accomplished by adopting both conventional and microwave-assisted Suzuki-Miyaura cross-coupling reaction between 3-hexylthiophene-2,5-diboronic ester 162 and 2,6-dibromo-1,5-naphthyridine 76 (previously prepared, vide supra, Figure 1) (Scheme 69) [40,97].

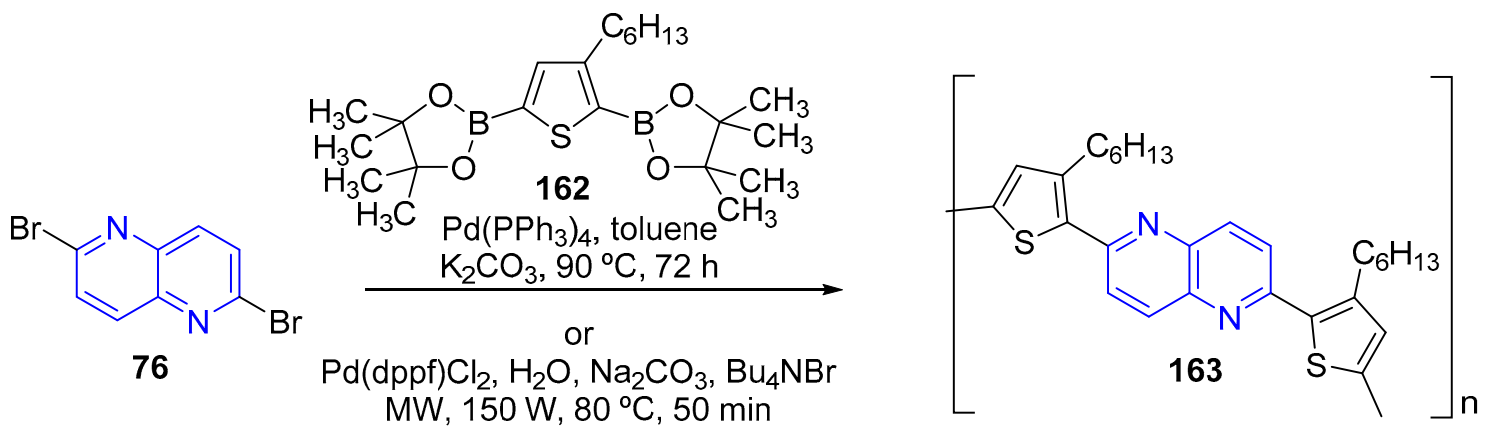

Scheme 69. Cross-coupling polymerization of dibromo-1,5-naphthyridine.

A series of 2,8-disubstituted-1,5-naphthyridine analogues were synthesized. The brominated key intermediate $\mathbf{7 3}$ (previously prepared, vide supra, Scheme 28) was subjected to a Suzuki cross-coupling reaction using commercially available boronates 164 (Scheme 70). A second Suzuki reaction using boronates 166 furnished the target compounds 167 [35].

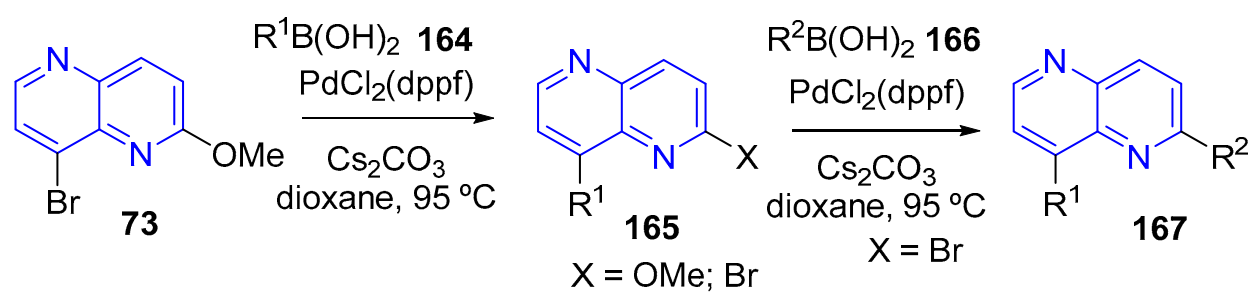

Scheme 70. Sequential Suzuki reaction.

Likewise, 4,8-substituted 1,5-naphthyridines 170 have been synthesized in yields of $41.4-75.8 \%$ from 4,8-dibromo-1,5-naphthyridine $\mathbf{1 6 8}$ and a wide range of boronic acids $\mathbf{1 6 9}$ in the presence of palladium acetate catalyst (Scheme 71) [20]. 
<smiles>Brc1ccnc2c(Br)ccnc12</smiles><smiles>[R]B(O)O[R](=O)OCC</smiles><smiles>[R]c1ccnc2c([R])ccnc12</smiles>

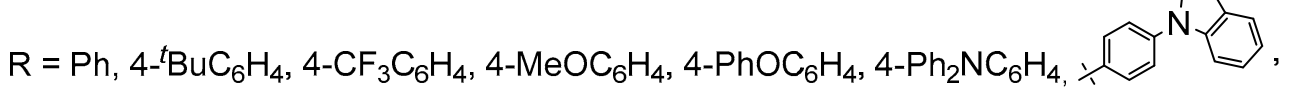

Scheme 71. Double arylation of 1,5-naphthyridines by cross-coupling reactions.

4-(4-tert-Butylphenyl)-8-methyl-1,5-naphthyridine 172 was prepared by the conversion of 4-hydroxy-8-methyl-1,5-naphthyridine 19b (previously prepared, vide supra, Scheme 6) to its triflate, followed by Suzuki coupling with 4-t-butylphenylboronic acid 171 (Scheme 72) [98].<smiles>Cc1ccnc2c(O)ccnc12</smiles>

$19 b$ i) Triflic anhydride

ii) 4-tert-butylphenylboronic acid 171 $\mathrm{Pd}\left(\mathrm{PPh}_{3}\right)_{4}$<smiles>Cc1ccnc2c(-c3ccc(C(C)(C)C)cc3)ccnc12</smiles>

172

Scheme 72. Suzuki coupling of hydroxy-1,5-naphthyridine mediated by triflic anhydride.

Other cross-coupling reactions have also been used for 1,5-naphthyridines. The Stille reaction was applied for the coupling between 1,5-naphthyridines and other heterocycles. Thus, 1,5-naphthyridine derivatives have been synthesized as new linkers for the construction of bridging ligands. These derivatives were prepared from the corresponding chloro-1,5-naphthyridine 71a (previously prepared, vide supra, Scheme 26), 72a (previously prepared, vide supra, Scheme 27) and $\mathbf{1 2 0}$ (previously prepared, vide supra, Scheme 44), which underwent Stille type reaction with 2-(tributylstannyl)pyridine $\mathbf{1 7 3}$ to afford the corresponding 1,5-naphthyridine derivatives 174-176 (Scheme 73) [74].<smiles>[R]c1cc([R])c2nc([R])ccc2n1</smiles>

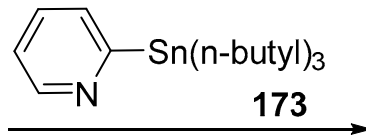

$\mathrm{Pd}\left(\mathrm{PPh}_{3}\right)_{4}$<smiles>[Y16]c1cccnc1-c1ccc2ncccc2n1</smiles>

174<smiles>FC(F)(F)c1ccnc2c(-c3ccccn3)ccnc12</smiles>

71a $\mathrm{R}^{1}=\mathrm{Cl} ; \mathrm{R}^{2}=\mathrm{R}^{3}=\mathrm{H}$

72a $R^{2}=\mathrm{Cl} ; \mathrm{R}^{1}=\mathrm{R}^{3}=\mathrm{H}$

$120 \mathrm{R}^{1}=\mathrm{R}^{3}=\mathrm{Cl} ; \mathrm{R}^{2}=\mathrm{H}$<smiles>OC(c1ccccn1)c1ccc2nc(-c3ccccn3)ccc2n1</smiles>

Scheme 73. Stille reaction to obtain pyridine-1,5-naphthyridines. 
This process has also been used for the synthesis of polymers 178. Both monomers and polymers were synthesized using typical Stille coupling reaction conditions, between 1,5-naphthyridine 43 (previously prepared, vide supra, Scheme 13) and 2-(tributylstannyl)thiophene 177 (Scheme 74) [37,49].

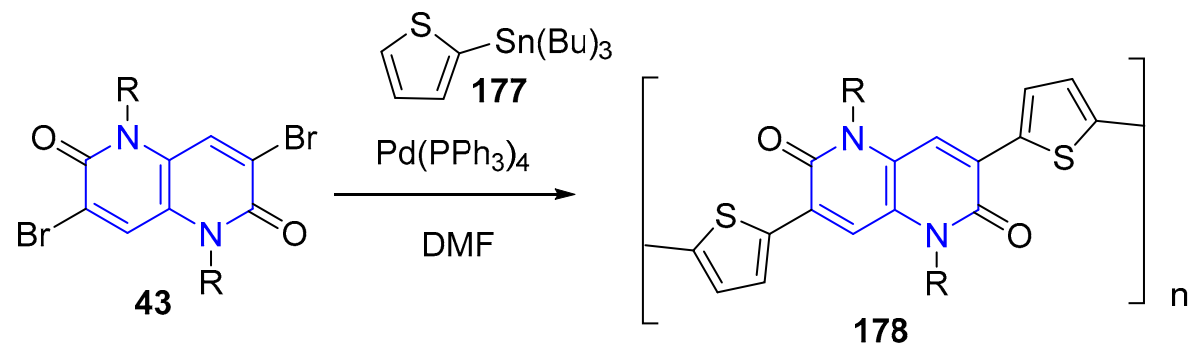

Scheme 74. Polymerization Stille coupling reaction of dibromo-1,5-naphthyridinones.

In a synthetic strategy developed by Knochel et al. involving silylated acetal-containing organometallic reagents for the construction of various polyfunctionalized 5-, 6-, and 7-membered heterocycles, Negishi coupling was also applied. The corresponding naphthyridine 179, which was readily treated with $\mathrm{TMPMgCl} \cdot \mathrm{LiCl}$ and after Negishi cross-coupling with ethyl 3-iodo-benzoate 180, provided the corresponding 4-substituted 1,5-naphthyridine $\mathbf{1 8 1}$ in 72\% yield (Scheme 75) [39].<smiles>[Y5]c1ccnc2cc(Cl)cnc12</smiles>

i) $\mathrm{TMPMgCl} \cdot \mathrm{LiCl},-40^{\circ} \mathrm{C}, 0.5 \mathrm{~h}$

ii) $\mathrm{ZnCl}_{2},-40^{\circ} \mathrm{C}$ to $25^{\circ} \mathrm{C}$

iii)

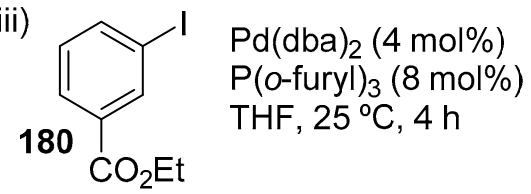<smiles>CCOC(=O)c1cccc(-c2c(Cl)cnc3c(S(C)(=O)=O)ccnc23)c1</smiles>

181

Scheme 75. Negishi cross-coupling of 1,5-naphthyridine.

Recently, practical and mild conditions have been developed for the Sonogashira synthesis of a variety of alkynyl benzenes and heteroarenes 183 in good to excellent yields, using CsF-mediated in situ TMSalkyne desilylation (Scheme 76). This method is accompained by excellent functional group tolerance and simple purification, which allows large-scale industrial applications. This one-pot protocol enables a high-yielding Sonogashira coupling with volatile alkynes by avoiding challenging isolation of free alkynes [99].

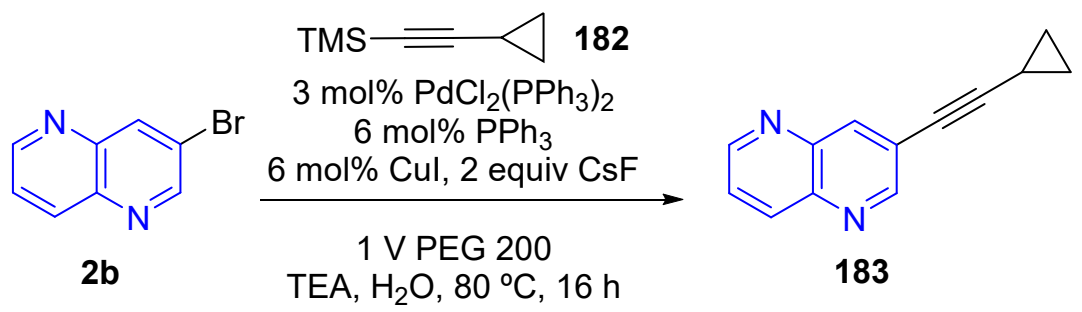

Scheme 76. Sonogashira coupling reaction of 3-bromo-1,5-naphthyridine.

In another study, 1,5-naphthyridines $\mathbf{1 8 5}$ have been directly C-H functionalized in a single step with a variety of tert-butoxycarbonyl (Boc)-protected aliphatic and cyclic amines $\mathbf{1 8 4}$ under Minisci photoredox conditions from unactivated coupling partners (Scheme 77). The high functional group 
tolerance and versatility of these transformations make them directly applicable to elaborate compounds 186 at the very last stage of synthesis [100].

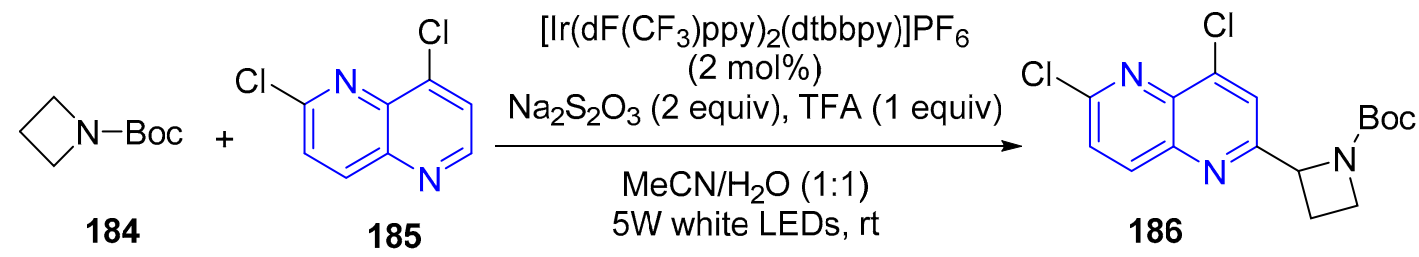

Scheme 77. Cross-coupling reaction under Minisci photoredox conditions.

\subsection{Modification of the Side Chain}

The substituents on the 1-5-naphthyridine ring have been subjected to a wide range of chemical transformations. Researchers at Pfizer modified the 2-methyl-3-methoxy-1,5-naphthyridine 2d (previously prepared, vide supra, Scheme 1) to give, after three steps, the 3-hydroxy-1,5naphthyridine-4-carbaldehyde 191 necessary for the preparation of a novel azetidinyl tethered ketolide series (Scheme 78) [13,14]. Before, the same group prepared the same carbaldehyde derivative 191 by synthesizing the hydroxyl derivative 188 followed by the proteccion of naphthyridine 190 [12].

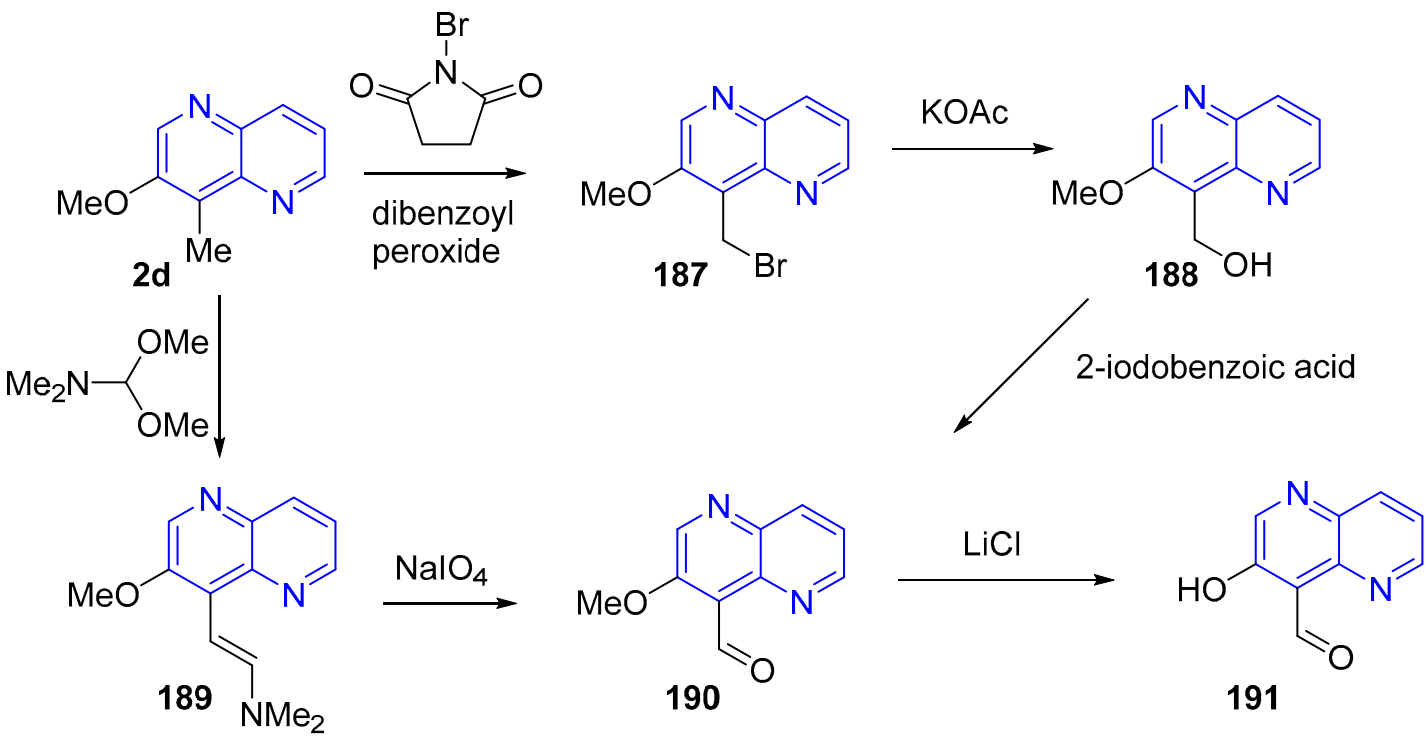

Scheme 78. Preparation of 1,5-naphthyridine-4-carbaldehyde from 1,5-naphthyridine 2 d.

For the synthesis of antibacterial drugs, after the preparation of $(E)$-alkenes 156a, $\mathbf{b}$ (previously prepared, vide supra, Scheme 66) and 192a,b with $E / Z$ selectivities bigger than $6 / 1$, the (1R,2S)-syn-diols 193a- $d$ were obtained by using $\mathrm{AD}-\mathrm{mix}-\beta$ or $\mathrm{OsO}_{4}$ as the dihydroxylating reagent. Reaction with $\mathrm{NaIO}_{4}$ yielded the corresponding aldehydes 190 (previously prepared, vide supra, Scheme 78) and 194. From compounds 193d, after removal of the tert-butoxycarbonyl (Boc) group with TFA, the resulting amine was transformed to 195 using different aromatic aldehydes via reductive amination reaction (Scheme 79) [65]. 
<smiles>[R]C=Cc1c([R])cnc2ccc(OC)nc12</smiles><smiles>[R]c1cnc2ccc(OC)nc2c1C=O</smiles>

$190 \mathrm{R}=\mathrm{H}$

$194 \mathrm{R}=\mathrm{F}$

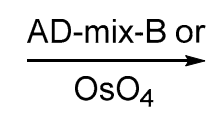
NHBoc $\mathrm{NalO}_{4}$

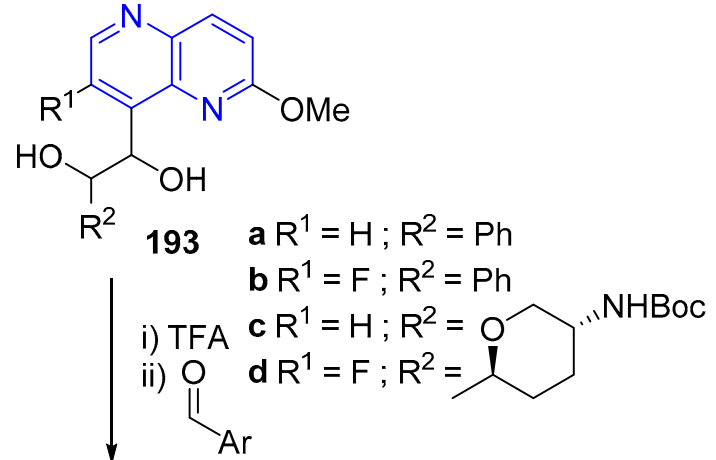<smiles>COc1ccc2nccc([C@@H](O)[C@H](O)[C@H]3CCCCO3)c2n1</smiles>

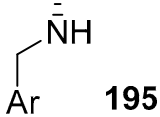

Scheme 79. Preparation of 1,5-naphthyridine derivatives 190, 194 and 195.

To achieve the synthesis of aminomethyl substituted naphthyridines, methyl 1,5-naphthyridine 172 (previously prepared, vide supra, Scheme 72) was reacted with $\mathrm{N}$-bromosuccinimide to afford the bromo methyl derivative 196 (Scheme 80). The treatment of this compound with DMF and 1,3-bis(tert-butoxycarbonyl)guanidine yielded the derivatives 197a,b [98].<smiles>Cc1ccnc2c(-c3ccc(C(C)(C)C)cc3)ccnc12</smiles>

172<smiles>Cc1ccnc2c(-c3ccc(C(C)(C)C)cc3)ccnc12</smiles>

196 i) $\mathrm{DMF}, \mathrm{K}_{2} \mathrm{CO}_{3}$ 1,3-bis(tert-butoxycarbonyl) guanidine, $16 \mathrm{~h}$

ii) TFA/DCM (1:1), $50^{\circ} \mathrm{C}$<smiles>[R]Nc1ccnc2c(-c3ccc(C(C)(C)C)cc3)ccnc12</smiles>

197 a $\mathrm{R}=\mathrm{H}$

b $\mathrm{R}=\underset{\mathrm{C}}{\mathrm{C}}=\mathrm{NH}$

Scheme 80. Preparation of compounds 197.

On the other hand, Fukuda et al. have been involved in the study of a series of oxabicyclooctanelinked as novel bacterial topoisomerase inhibitors (NBTIs). A hydroxyl group in the linker was optimal for activity. The preparation of these alcohols 199 took place through addition of the deprotonated 8-methyl-1,5-naphthyridine $\mathbf{1 3 1}$ (previously prepared, vide supra, Scheme 54) to the corresponding aldehyde 198a or ketone $\mathbf{1 9 8 b}$ (Scheme 81) [25,91]. 
<smiles>COc1ccc2ncc(F)c(C)c2n1</smiles>

131

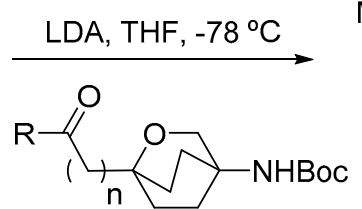

198 a $R=H \quad n=0,1$

$$
\text { b } \mathrm{R}=\mathrm{CH}_{3}
$$

BocHN

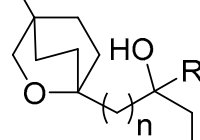<smiles>COc1ccc2ncc(F)c(C)c2n1</smiles>

199

Scheme 81. Synthesis of alkohol derivatives 199.

The precursors of biologically interesting naphthyridine aminothiazoles are the carbonyl derivatives 201 (Scheme 82). They were readily prepared by metalation of 2-methyl-1,5-naphthyridines 2e (previously prepared, vide supra, Scheme 1) or $\mathbf{4 a}$ (previously prepared, vide supra, Scheme 2), in the presence of potassium bis(trimethylsilyl)amide at low temperature, and treatment with the corresponding aryl or pyridyl $(X=N)$ esters 200. The resulting ketones 201 were used in the subsequent step without purification $[15,101]$.

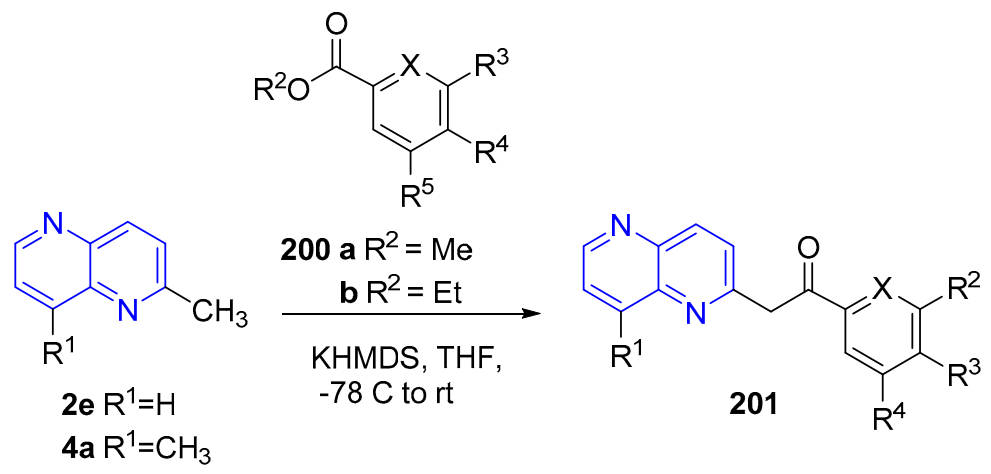

Scheme 82. Synthesis of carbonylic compounds 201.

1,5-Naphthyridine-3-carboxylates 202 were hydrolysed to prepare the corresponding 1,5-naphthyridine-3-carboxylic acid derivatives 203 (Scheme 83) [22]. On the other hand, from either carboxylate 202 or carboxylic acid 203, 6-ethoxy-4-oxo-1,4-dihydro-1,5-naphthyridine-3-carboxylic benzylamide 204 was obtained. In this context, Ripin et al. described a multikilogram scale synthesis of 204 [23].<smiles>[R6]c1ccc2[nH]cc(C(=O)OCC)c(=O)c2n1</smiles>

Scheme 83. Synthesis of 1,5-naphthyridine carboxylic acids 203 and carboxamides 204.

Structure-based design and molecular modeling has been used for the preparation of 1,5-naphthyridine with an amide substituent in their structure. The synthesis of the naphthyridine 
amide derivative 206 was realized by the reaction of an acyl chloride 205 with 1,5-naphthyridine-4-amine $\mathbf{8 4 b}$ (previously prepared, vide supra, Scheme 31) in high yield (Scheme 84). Analogues, but "reversed" 1,5-naphthyridine amide derivatives 207 were prepared by a standard peptide coupling conditions between 1,5-naphthyridine carboxylic acid and an amine derivative (Scheme 84) [102].

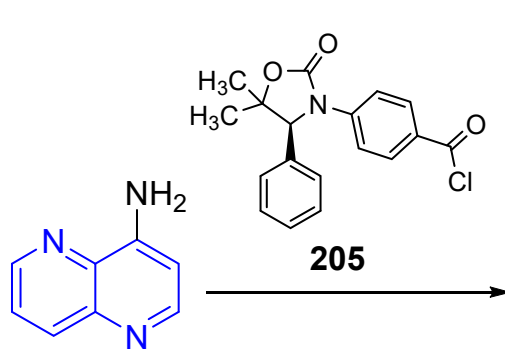

$84 b$<smiles>CC1(C)OC(=O)N(c2ccc(C(=O)Nc3ccnc4cccnc34)cc2)[C@H]1c1ccccc1</smiles>

206<smiles>[R]c1cnc2c(C(=O)NC3CCC(N4C(=O)OC(C)(C)[C@H]4c4ccccc4)CC3)ccnc2c1</smiles>

207

Scheme 84. Preparation of functionalized amides 206 and 207.

1,5-Naphthyridine derivatives have been synthesized as new linkers for the construction of bridging ligands. These derivatives were prepared from a 1,5-naphthyridine to give the corresponding cyano 1,5-naphthyridine derivatives 121 (previously prepared, vide supra, Scheme 45), then these compounds were reacted with methyl magnesium bromide to afford ketones 208 (Scheme 85) [74]. The phenylhydrazone 209 derived from 2-acetyl-1,5-naphthyridine 208a was obtained by the reaction with phenylhydrazine (Scheme 85) [103].

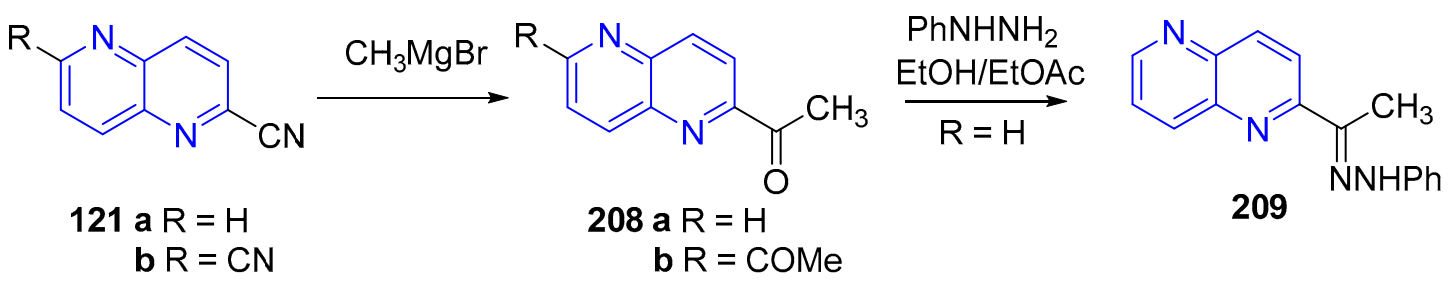

Scheme 85. Synthesis of ketones 208 and hydrazone 209 from nitriles 121.

On the other hand, some C-2 O-alkylated 1,5-naphthyridine oxabicyclooctane-linked compounds 211 were selectively synthesized by the alkylation of 2-hydroxy-naphthyridyl intermediate $\mathbf{2 1 0}$ with appropriately protected alkyl bromides, methyl bromide or more complexes to control quirality, in the presence of a base $\left(\mathrm{K}_{2} \mathrm{CO}_{3}\right)$ (Scheme 86) [104].

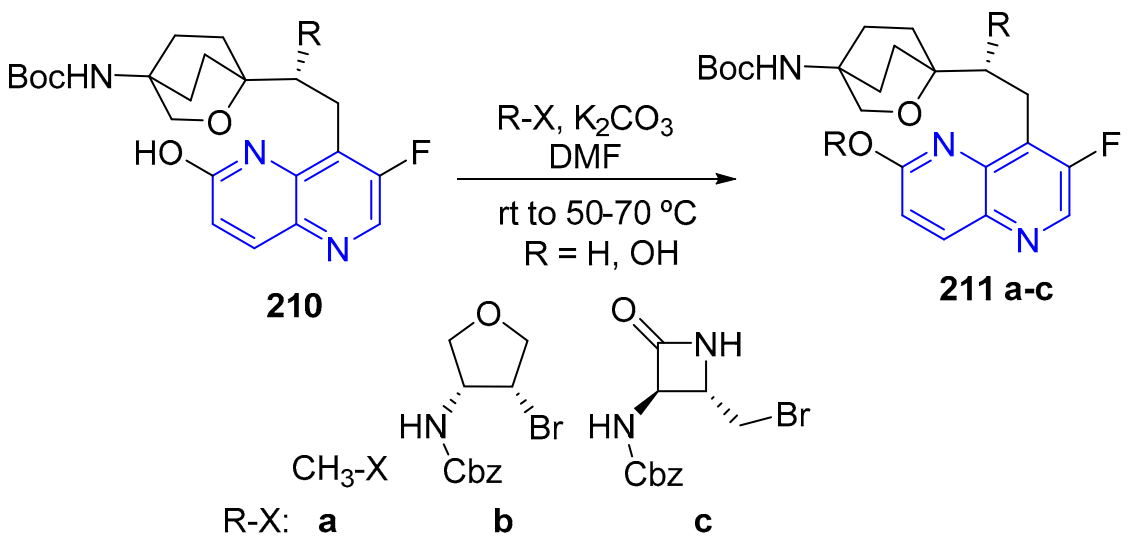

Scheme 86. O-Alkylation of hydroxyl-1,5-naphthyridines. 
In contrast, the dealkylation of the ether moiety was also reported. For example, a $O$-demethylation of the ether group (OMe) linked to the naphthyridine ring $\mathbf{2 1 2}$ was performed with hydrogen bromide to obtain the corresponding 1,5-dihydro-1,5-naphthyridine-2,6-dione $\mathbf{4 1}$ (previously prepared, vide supra, Scheme 13), which was subjected to further functionalization (Scheme 87) [37]. Likewise, a similar strategy with aqueous $\mathrm{HCl}(6 \mathrm{M})$ was used to demethylate the methoxy group at $\mathrm{C}-2$ to give the 1,5-naphthyridine 213 [53].<smiles>COc1ccc2[nH]c(=O)ccc2n1</smiles>
212
41<smiles></smiles>

conditions: $\mathrm{HCl} 6 \mathrm{M}$

Scheme 87. Acid O-demethylation of methoxy naphthyridines to obtain compounds 41 and 213.

Previously prepared amino intermediates 214 were derivatized by reductive amination with bis(trifluoromethyl) benzaldehyde 215 to give derivatives $N$-benzyl amino derivatives 216 and by a further acetylation to afford the corresponding 1,5-tetrahydronaphthyridines 217 (Scheme 88) [47].

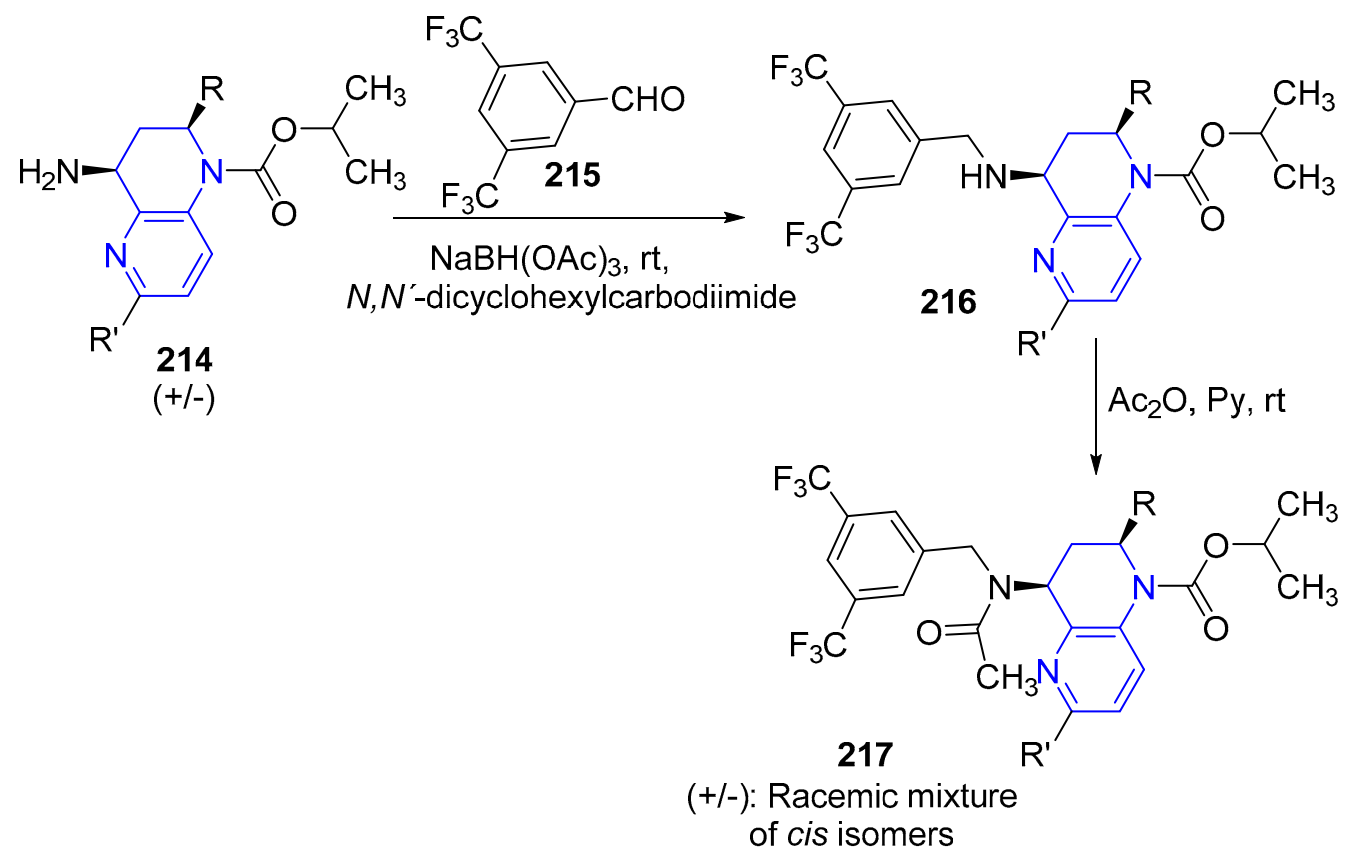

Scheme 88. N-Functionalizations of compounds 214 to obtain derivatives 217.

The scale-up synthesis of the antibacterial azetidinyl ketolide 219 was achieved by a reductive amination between the 1,5-naphthyridine aldehyde 191 (previously prepared, vide supra, Scheme 78) and some clarithromycin derivatives 218 (Scheme 89) [13].

In the synthesis of 1,5-naphthyridin-2-yl ureas 222 and 223, azaheterocyclic amines 220 were reacted with various isocyanates 221, in pyridine at reflux or in two steps in the presence of triphosgene, trimethylamine and then adding the desired amine (Scheme 90) [10,32]. 
<smiles>[R][R]([H])=CC=C</smiles>

i)<smiles>O=Cc1c(O)cnc2cccnc12</smiles><smiles>N#Cc1c(O)cnc2cccnc12</smiles>

ii) $\mathrm{Na}(\mathrm{OAc})_{3} \mathrm{BH}$

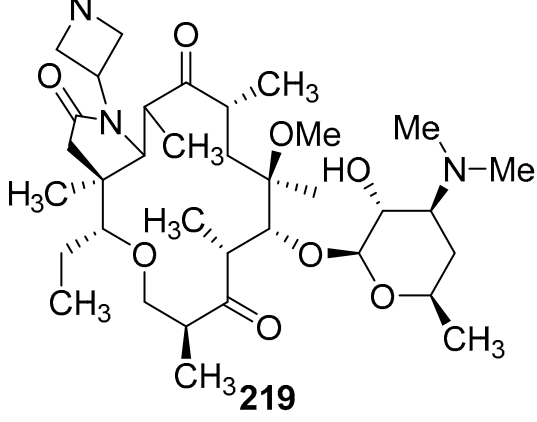

Scheme 89. Reductive amination of compounds 218 to obtain derivative 219 .<smiles>N=Nc1ncccc1N</smiles>

220

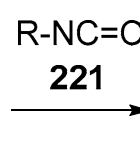<smiles>[R]NC(=O)Nc1ncc2ncccc2n1</smiles>

222<smiles>CN(C)c1ccc(NC(=O)Nc2ccnc3cccnc23)cc1</smiles>

223

Scheme 90. Synthesis of functionalized urea derivatives 222 and 223.

In the same context, a series of diarylurea analogues of SB-334867 were obtained from 4-amino 1,5-naphthyridine $\mathbf{8 4 b}$ (previously prepared, vide supra, Scheme 31) with the appropriate 4-nitrophenylisocyanate followed by reduction of the nitro group to the corresponding amine and a reductive alkylation to obtain 225 (Scheme 91) [105]. Lewin et al. reported a new method for the preparation of 1-(2-methylbenzoxazol-6-yl)-3-(1,5-naphthyridin-4-yl) urea 225 (SB-334867, Scheme 91) containing a very labile 2-methylbenzoxazole ring system, from 4-amino-1,5-naphthyridine $84 \mathrm{~b}$ involving a coupling reaction with $\mathbf{2 2 4}$. The stability and the solubility of the compound was studied and it was found to be stable in DMSO for at least one year [64].

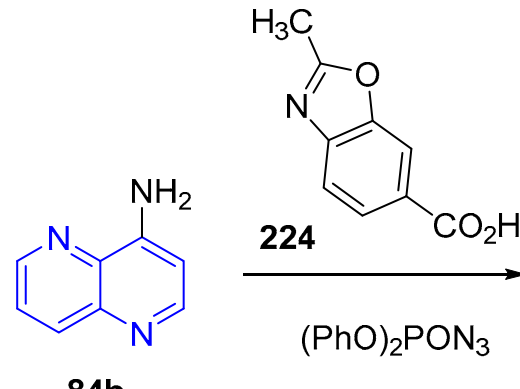

84b<smiles>Cc1nc2ccc(NC(=O)Nc3ccnc4cccnc34)cc2o1</smiles>

225

Scheme 91. Preparation of diarylurea SB-334867.

1,5-Naphthyridines substituted at the position 2 with an indol, 2-(1'H-indol-2'-yl)-1,5-naphthyridine 226, underwent phototransformation upon $365 \mathrm{~nm}$ irradiation in acetonitrile at ambient temperature in the 
presence of air [106]. The experimental results, combined with the simulations of electronic and infrared (IR) spectra showed two photoproducts, the 2-(1,5-naphthyridin-2-yl)-4H-3,1-benzoxazin-4-one 227 as major product and N-(2-formylphenyl)-1,5-naphthyridine-2-carboxamide 228 as minor (Scheme 92). The results of this study can help in developing an efficient and easy method for the synthesis of molecules with a benzoxazinone structure.<smiles>O=[R6]c1cc2ccccc2[nH]1</smiles>

(syn/anti rotamers)

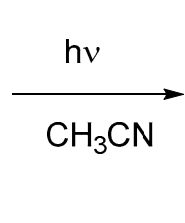

(syn/anti rotamers)<smiles>O=c1oc(-c2ccc3ncccc3n2)nc2ccccc12</smiles>

(4:1)<smiles>O=Cc1ccccc1NC(=O)CCCCOc1cccc(O)n1</smiles>

(syn/anti rotamers)

Scheme 92. Photochemical addition of acetonitrile to naphthyridine 226.

\subsection{Formation of Metal Complexes}

The 1,5-naphthyridine compounds, when used as ligands in metal complexes, comprise two $\mathrm{N}$-donor atoms, which, for geometric reasons, cannot bind to the same metal atom. In addition, when 1,5-naphthyridines form complexes with transition metals, they may behave either as mono or as bidentate ligands. In this section, coordination complexes will be classified by the nature of metal according to their appearance in the periodic table.

For example, in 1,5-naphthyridin-8-yl-functionalized cyclopentadiene (Cp) and indene (Ind) ligands, the N5 is in a position to activate potential ligand-coupling reactions, while N1 can coordinate to a metal in a manner analogous to 8-quinolyl-functionalized $\mathrm{Cp}$ and Ind ligands. In this sense, the formation of a 1,5-naphthyridine complex with $\mathrm{Zr}(\mathrm{NMe})_{4}$ was studied [62]. Both components reacted quickly at room temperature with formation of complex $\mathbf{2 2 9}$ as the only product together with free $\mathrm{HNMe}_{2}$. This complex could be converted to the stable chloro derivative complex 230 by the addition of $\mathrm{Me}_{3} \mathrm{SiCl}$ (Scheme 93).

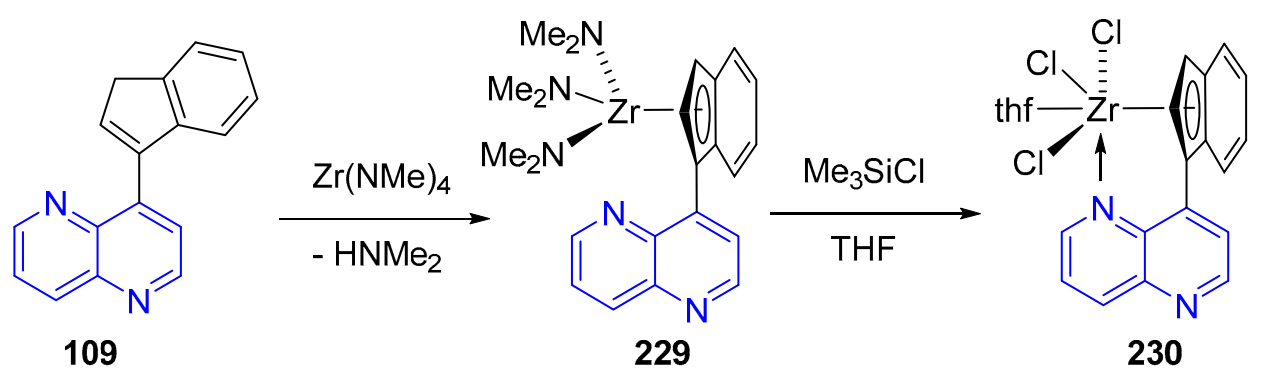

Scheme 93. Preparation of zirconium complexes 229 and 230.

A chromium (III) complex 1,5-naphthyridine trans-diaquadioxalatochromate(III) dehydrate 231, was synthesized by self-assembly of chromium(III) nitrate with oxalic acid and 1,5-naphthyridine 2a (previously prepared, vide supra, Scheme 1) to obtain violet crystals suitable for X-ray diffraction (Scheme 94) [107]. The structures were obtained as organic layers, built up by the 1,5-naphthyridine cations, arranged in a sandwich between the layers of the $\left[\mathrm{Cr}\left(\mathrm{C}_{2} \mathrm{O}_{4}\right)_{2}\left(\mathrm{H}_{2} \mathrm{O}\right)_{2}\right]$-complex anion and free water molecules. Also from 1,5-naphthyridine, paddlewheel-type dichromium(II,II) tetraacetate complex 232 was successfully prepared by liquid-liquid interdiffusion with chromium(II) acetate $\left(\mathrm{Cr}(\mathrm{Ac})_{2}\right)$ in acetonitrile with a layer of pure $\mathrm{CH}_{3} \mathrm{CN}$ separating the two phases in a narrow glass tube (Scheme 94) [108]. 


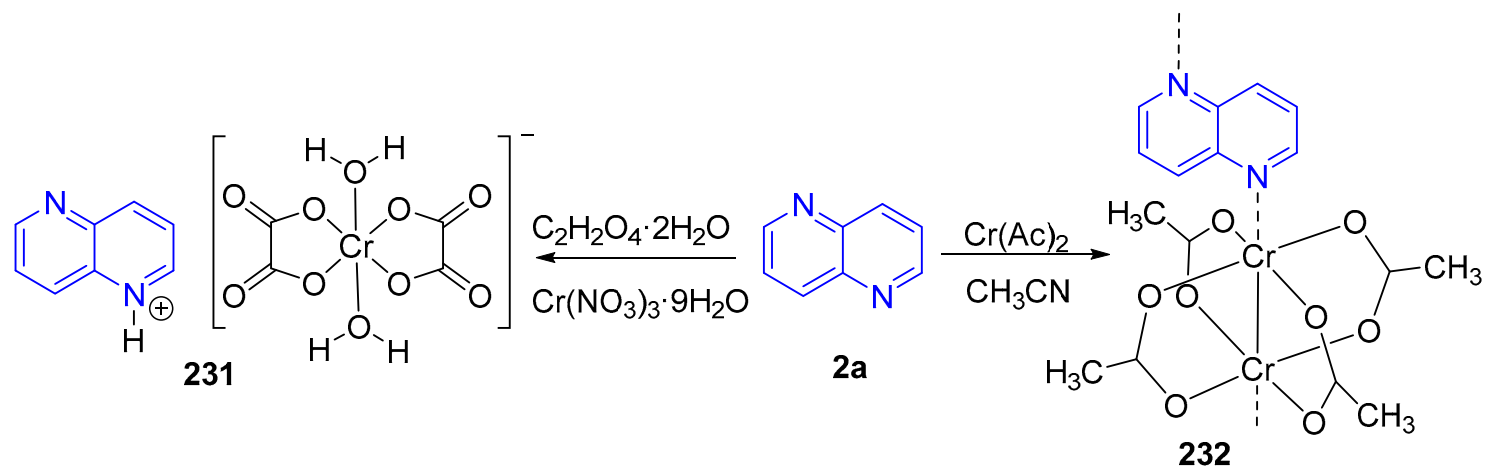

Scheme 94. Formation of chromium complexes 231 and 232.

Starting from functionalized cyclopentadienyl-1,5-naphthyridines $\mathbf{1 1 0}$ (previously prepared, vide supra, Scheme 40) and $\mathbf{2 3 3} \mathbf{3}, \mathbf{b}$, a variety of chromium(III) half-sandwich complexes $\mathbf{2 3 4}$ have been obtained (Scheme 95) [109].<smiles>CS(=O)c1ccnc2cccnc12</smiles>

108

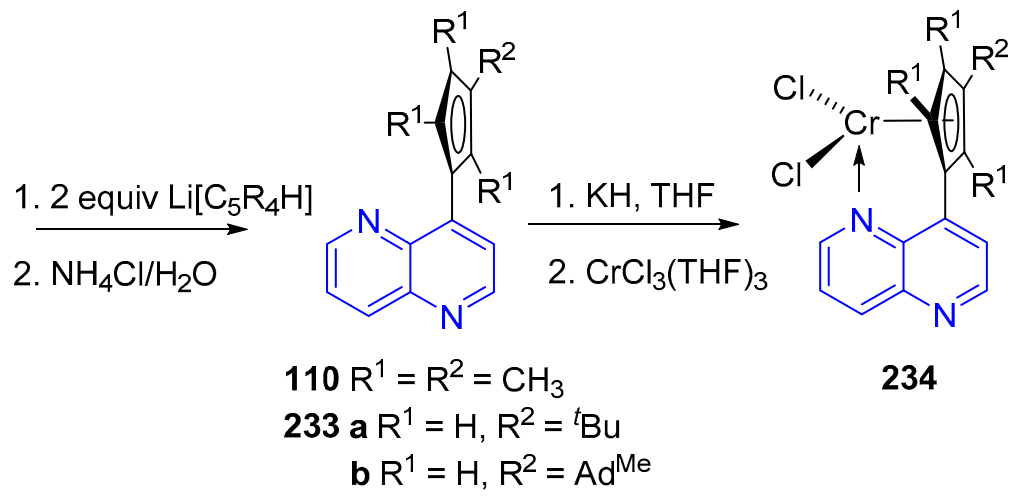

Scheme 95. Formation of chromium(III) complex 234.

When using a 1,5-naphthyridine nucleus with $N$-heterocyclic substituent as a coordinating entity in a reaction with $\left[\mathrm{Ru}\left(\mathrm{bpy}-\mathrm{d}_{8}\right)_{2} \mathrm{Cl}_{2}\right]$, a wide variety of ruthenium complexes with bidentate and tridentate ligands, have been obtained [74]. For example, the treatment of 2-(pyridin2-yl)-1,5-naphthyridine 174 (previously prepared, vide supra, Scheme 73) with 1 equiv. of [Ru(bpy$\left.\mathrm{d}_{8}\right)_{2} \mathrm{Cl}_{2}$ ] furnished the corresponding heteroleptic $\mathrm{Ru}(\mathrm{II})$ complex 235 (Scheme 96), while the treatment of 2-(1,5-naphthyridin-2-yl)-1,10-phenanthroline 236 with 1 equiv. of $\left[\mathrm{Ru}(\mathrm{tpy})_{2} \mathrm{Cl}_{3}\right]$ afforded the corresponding heteroleptic $\mathrm{Ru}$ (II) complex 237 containing a tridentate ligand (Scheme 96). On the other hand, many of these ligands, as for example compound $\mathbf{1 7 6}$ (previously prepared, vide supra, Scheme 73), posses bisubstituted 1,5-naphthyridine scaffold as a linker between the two equivalent coordinating sites giving rise to both bis-bidentate and bis-tridentate ligands. When reacting with 2 equiv. of $\left[\mathrm{Ru}\left(\mathrm{bpy}-\mathrm{d}_{8}\right)_{2} \mathrm{Cl}_{2}\right]$ or $\left[\mathrm{Ru}(\mathrm{tpy})_{2} \mathrm{Cl}_{3}\right]$, complexes 238 and 239 can be obtained, respectively (Scheme 96). The efficiency of the 1,5-naphthyridine linker has been compared to the previously studied pyrazine linker, and the latter is found to promote better communication between the two bound metals.

Cabeza et al. reported the synthesis of a triruthenium cluster compound containing cationic 1,5-naphthyridine ligand 241 by treatment of $\left[\mathrm{Ru}_{3}(\mathrm{CO})_{12}\right]$ with the neutral $\mathrm{N}$-heterocycle $2 \mathbf{a}$ and subsequent methylation of the product $\mathbf{2 4 0}$ with trimethyloxonium tetrafluoroborate as the methylating reagent (Scheme 97) [110]. 


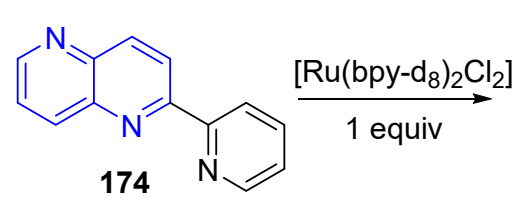

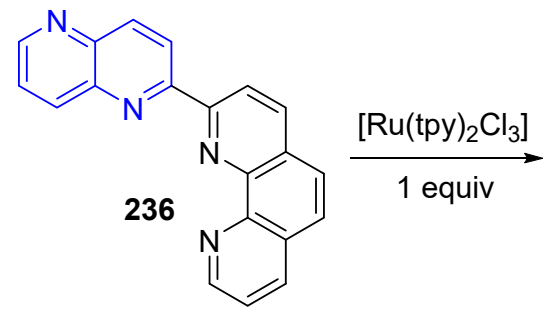

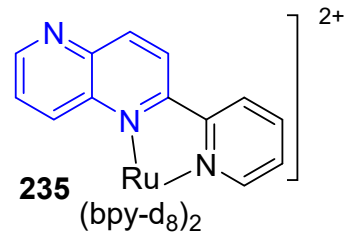

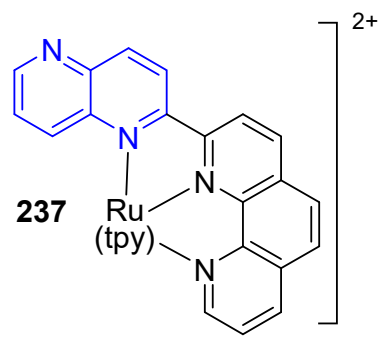

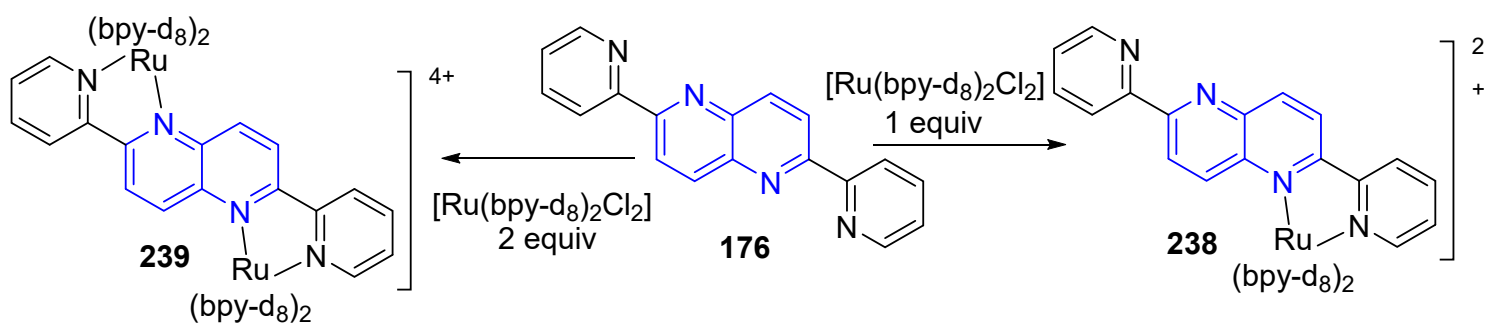

Scheme 96. Preparation of heteroleptic ruthenium(II) complexes 235, 237-239.

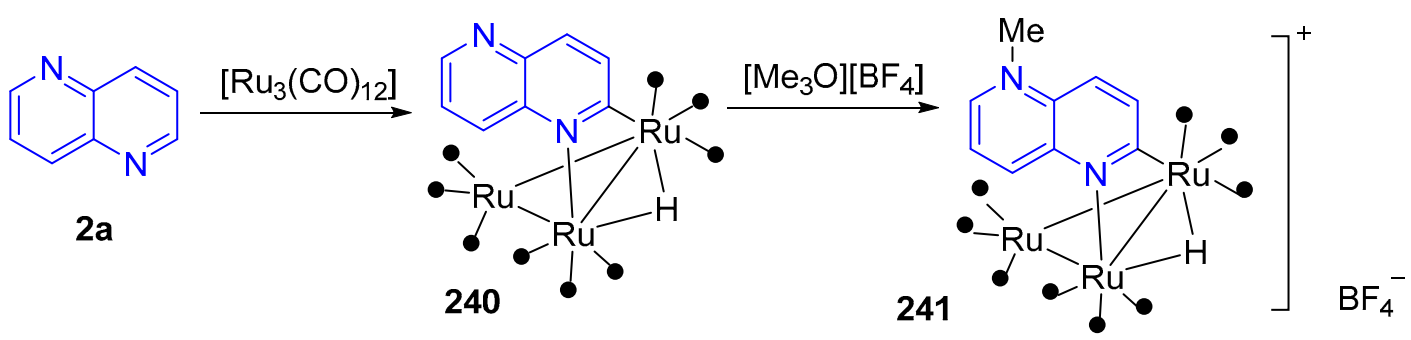

Scheme 97. Formation of triruthenium cluster compounds 240-241.

The heteroleptic ruthenium(II) complex, $\left[\mathrm{Ru}(\mathrm{bpy})_{2}(\mathrm{Me}-\mathrm{pn})\right]\left(\mathrm{PF}_{6}\right)_{2}$ 243, 2-methyl-6-(pyridin2-yl)-1,5-naphthyridine 242 ligand, has been prepared under photochemical reduction conditions (Scheme 98) [111].<smiles>[R20]c1ccc(C)nc1-c1ccccn1</smiles>
242

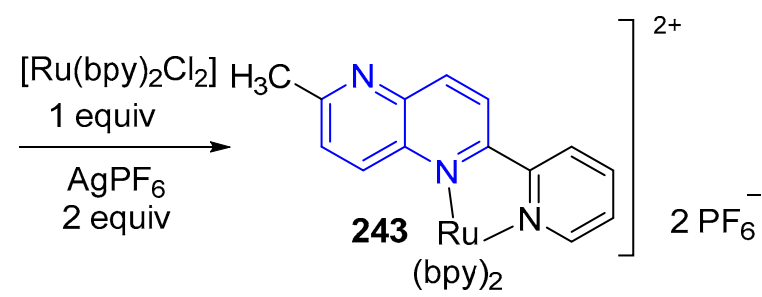

Scheme 98. Synthesis of heteroleptic ruthenium(II) complex 243.

The synthesis of rhodium complexes of 1,5-naphthyridines was accomplished by the coupling of a $N$-donor-functionalized indenyl and cyclopentadienyl-1,5-naphthyridine unit (Scheme 99) [62]. The synthesis of the red Rh(III) complexes, 245 and 246 was achieved by reaction of the deprotonated ligand 110 or 109 (previously prepared, vide supra, Scheme 40) with the rhodium precursor, di- $\mu$-chlorodicyclooctadienyldirhodium. For the synthesis of the binuclear derivative 247, BuLi was used before the rhodium was added. 


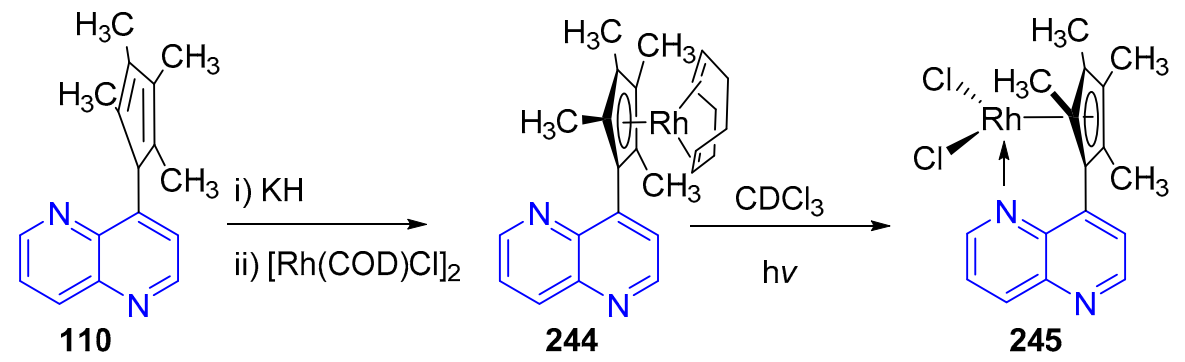

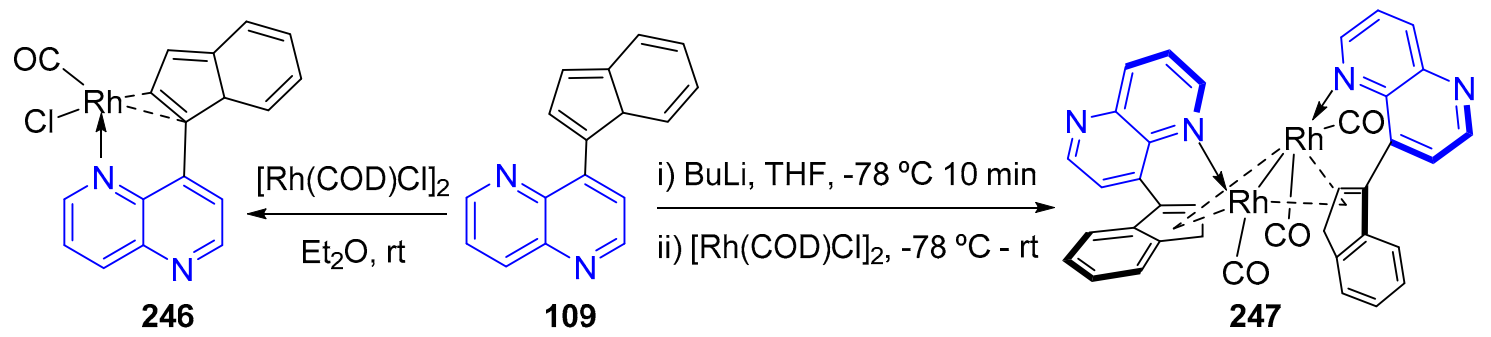

Scheme 99. Formation of rhodium complexes 244-247.

Walmsley et al. investigated the interactions of 1,5-naphthyridine with $\mathrm{Pd}(\mathrm{II})$ in aqueous solution by $1 \mathrm{D}$ and $2 \mathrm{D}^{1} \mathrm{H}$ NMR spectroscopy and potentiometric titration [112]. In this study, they observed that 1,5-naphthyridine acts as a ligand coordinating to $\mathrm{Pd}(\mathrm{II})$, in either $\left[\mathrm{Pd}(\mathrm{en})\left(\mathrm{H}_{2} \mathrm{O}\right)_{2}\right]\left(\mathrm{NO}_{3}\right)_{2}$ or $\mathrm{Pd}(\mathrm{en}) \mathrm{Cl}_{2}$ form, in aqueous solutions to produce the 2:1 and 1:1 complexes, compounds 248 and 249 respectively (Scheme 100), as well as a 1:2 oligomeric species 250. Some other different complexes were observed when $\mathrm{pH}$ was modified (not indicated) (Scheme 100).<smiles>[X][P]1(N2C=CC=C3C2=CC=CN3[P+]2([Y])NCCN2)NCCN1</smiles>

248<smiles></smiles>

249<smiles></smiles>

250

Scheme 100. Interconversion of palladium(II) complexes derived from 1,5-naphthyridine in aqueos solutions.

Heteroleptic platinum(II) complexes bearing two ligands, hydroxynaphthyridine and 2-(2,4-difluorophenyl)pyridine, were synthesized in two steps $[19,113]$. The first ligand 251 was attached by treatment with $\mathrm{K}_{2} \mathrm{PtCl}_{4}$ to form platinum dichloride-bridged dimer 252, followed by reaction with naphthyridinol derivatives 19a,b (previously prepared, vide supra, Scheme 6) or 253a,b as second ligand in 2-ethoxyethanol to yield complexes 254 (Scheme 101).

Copper(I) mixed-ligand complexes, $\left[\mathrm{Cu}_{2}(\mu-\mathrm{Br})_{2}\left(\mathrm{PPh}_{3}\right)\right](\mathrm{L})_{\mathrm{n}} 255$, including a 1,5-naphthyridine ring were prepared by reaction with 5 equiv. of $\mathrm{CuBr}$ and 5 equiv. of $\mathrm{PPh}_{3}$ and obtained as crystalline materials (Scheme 102) [114]. Bidentate ligands, such as 1,5-naphthyridine 2a (previously prepared, vide supra, Scheme 1), formed infinite chain complexes 255 with the ligands bridging the dimeric units. 


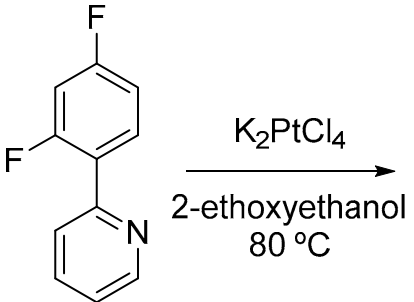

251

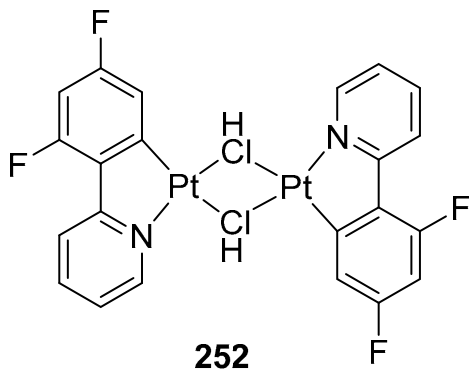

252<smiles>[R2]c1cc(O)c2nccc([R])c2n1</smiles>

19 a $R^{1}=R^{2}=H$

b $\mathrm{R}^{1}=\mathrm{CH}_{3} ; \mathrm{R}^{2}=\mathrm{H}$

253 a $\mathrm{R}^{1}=\mathrm{CH}_{3} ; \mathrm{R}^{2}=\mathrm{CO}_{2} \mathrm{Et}$

b $\mathrm{R}^{1}=\mathrm{CH}_{3} ; \mathrm{R}^{2}=\mathrm{CO}_{2} \mathrm{CH}_{2} \mathrm{CH}_{2} \mathrm{OEt}$

Scheme 101. Formation of heteroleptic platinum(II) complexes 254.<smiles>c1cnc2cccnc2c1</smiles>

$2 a$

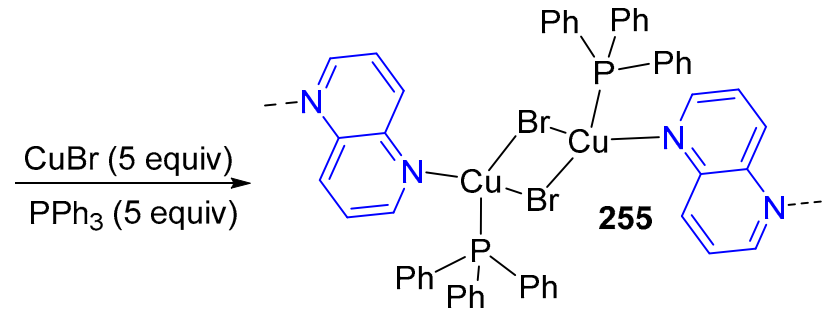

Scheme 102. Synthesis of copper(I) mixed-ligand complex 255.

Later on, the homoleptic $\mathrm{Cu}(\mathrm{I})$ complexes 257 were obtained by the reaction of 4-diphenylphosphino-1,5-naphthyridine ligands 256 with $\left[\mathrm{Cu}\left(\mathrm{CH}_{3} \mathrm{CN}\right)_{4}\right] \mathrm{PF}_{6}$ in $\mathrm{CH}_{3} \mathrm{OH} / \mathrm{CHCl}_{3}$ (Scheme 103) [115].<smiles>[R]c1ccnc2c(P)ccnc12</smiles>

256

$\mathrm{R}=\mathrm{H}, \mathrm{CH}_{3}$

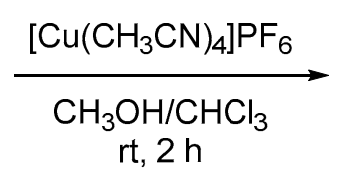

$\mathrm{rt}, 2 \mathrm{~h}$$$
\text { (1) }
$$

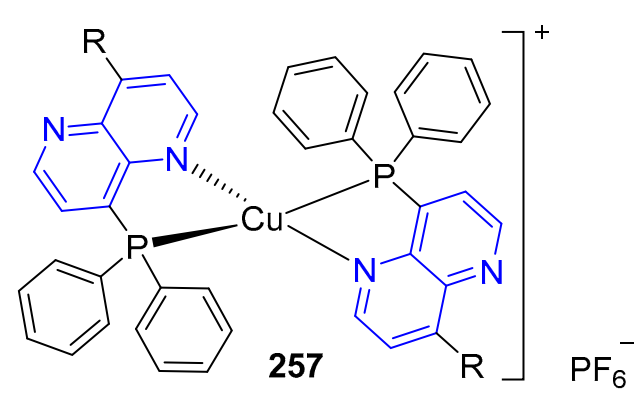

257

Scheme 103. Preparation of homoleptic copper(I) complex 257.

When 1,5-naphthyridine dimers were used, copper(II) complexes were prepared with cooper(II) nitrate producing a discrete mononuclear complex in which the copper atom is chelated to the central internal nitrogens, demonstrating that the ligand could act in a variety of coordination modes [63]. In this work, copper complexes, as well as silver and palladium complexes were obtained in a similar way. Polynuclear silver(I) complexes with 1,5-naphthyridines were also synthesized by the reaction of the three $\mathrm{AgX}$ salts $\left(\mathrm{X}=\mathrm{NO}_{3}{ }^{-}, \mathrm{CF}_{3} \mathrm{COO}^{-}\right.$and $\left.\mathrm{CF}_{3} \mathrm{SO}_{3}{ }^{-}\right)$and 1,5-naphthyridine in ethanol at room temperature [116]. 
Regarding gold complexes, Pyykko et al. reported a computational study of some gold complexes of 1,5-naphthyridines [117]. In this case, it is indicated that gold atom can act as an intermolecular glue, coupling(hetero)aromatic rings, typically through $\mathrm{C}-\mathrm{Au} \leftarrow \mathrm{N}$ bonds.

Matsui et al. used 1,5-naphthyridines complexed with zinc as a template molecule for the polymerization of porphyrin monomer units 259 (Scheme 104), in a bottom-up architecture construction of supramolecules consisting of two face-to-face porphyrins [118]. A schematic representation of a face-to-face arrangement of two porphyrins is shown in Scheme 104. In this case, 1,5-naphthyridine 2a (previously prepared, vide supra, Scheme 1) acts as a linker through bidentate zinc complexation in intermolecular interactions of porphyrins.

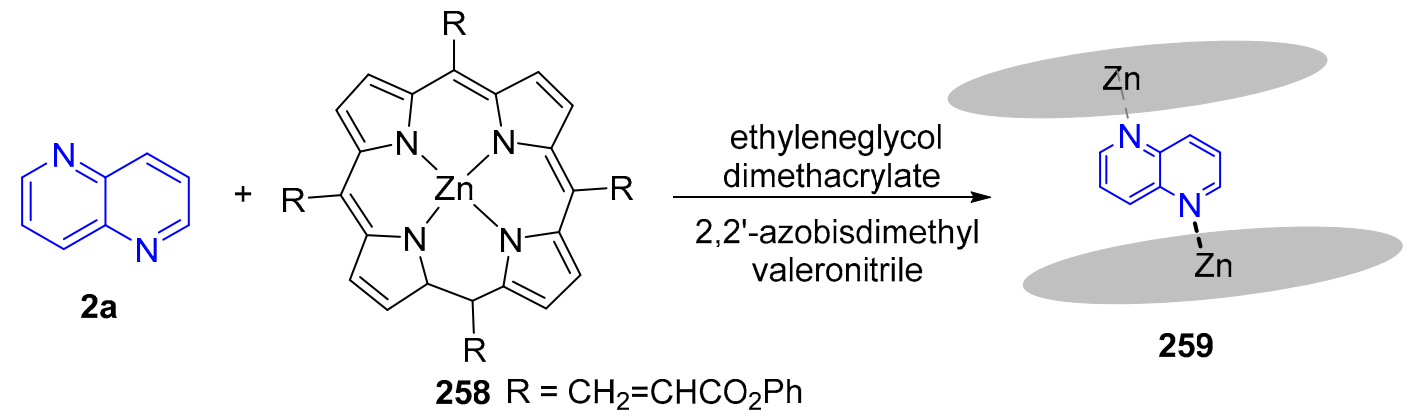

Scheme 104. Preparation of complex 259 with a 1,5-naphthyridine bidentate ligand.

Moreover, also $\mathrm{ML}_{2 \times 2}$ type $\mathrm{Zn}(\mathrm{II}), \mathrm{Co}(\mathrm{II})$ and $\mathrm{Ni}(\mathrm{II})$ complexes were prepared from 1,5naphthyridines [119].

A series of europium complexes with structurally rigid 4-hydroxy-1,5-naphthyridine ligands were developed [120]. The $\mathrm{Eu}^{3+}$ ion owns large radius and thus usually requires high coordination number of 8 or 9 to stabilize the coordination environment [121]. Therefore, when using bidentate ionic ligands, such as 4-hydroxy-1,5-naphthyridines 260 , to construct $\mathrm{Eu}^{3+}$ complexes, there are two typical synthetic strategies, ratio 3:1 (ionic ligands versus $\mathrm{Eu}^{3+}$ ions) plus one or more additional neutral ligands, or ratio 4:1 without any other neutral ligands. The latter strategy was adopted by Bian et al. and the 4-hydroxy-1,5-naphthyridine-based europium complexes $\mathbf{2 6 1}$ were synthesized with the structure of $\mathrm{Na}^{+}\left[\mathrm{Eu}(\mathrm{NDs})_{4}\right]^{-}$, where each $\mathrm{Eu}^{3+}$ ion is chelated by four 1,5-naphthyridine ligands, and one $\mathrm{Na}^{+}$ion was incorporated as the counter ion (Scheme 105). For the synthesis, a mixture of $\mathrm{ND}$-ligand and $\mathrm{NaOH}$ in ethanol was refluxed for $10 \mathrm{~min}$ and the suspension was then poured into a solution of $\mathrm{EuCl}_{3} \cdot 6 \mathrm{H}_{2} \mathrm{O}$ and stirred overnight at reflux temperature. The same group prepared $\mathrm{Eu}$ (III) complexes with tridentate ligands, such as 8-hydroxy-1,5-naphthyridine-2-carboxylic acid [28] and 6-(diphenylphosphoryl)-4-hydroxy-2-methyl-1,5-naphthyridine [29] by the "self-assembly" of the ligand, $\mathrm{NaOH}$, and $\mathrm{EuCl}_{3} \cdot 6 \mathrm{H}_{2} \mathrm{O}$ in a ratio of 3:3:1 in methanol.

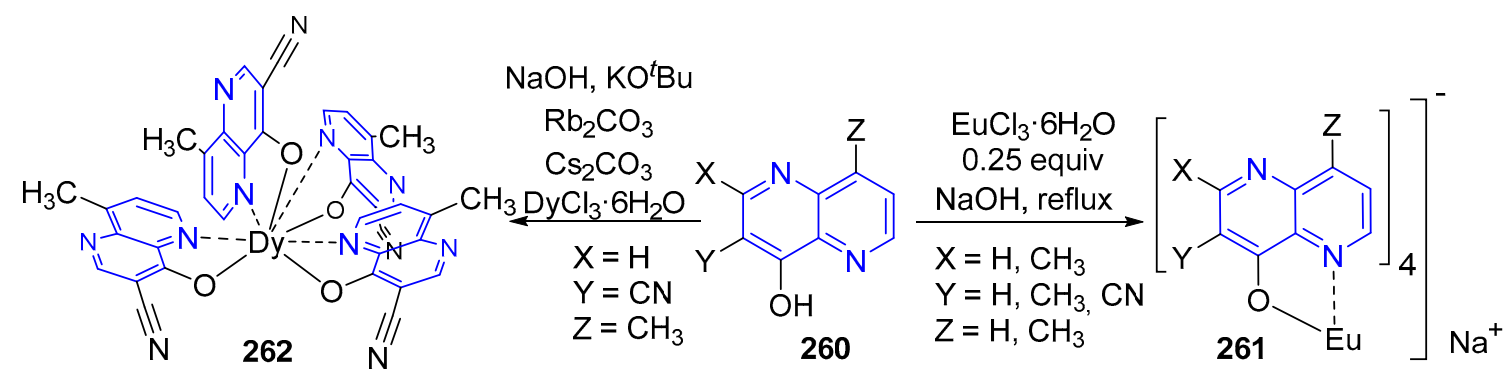

Scheme 105. Formation of europium complexes 261 and dysprosium complex 262.

In addition, a series of dysprosium(III) ion coordinated by four chelated naphthyridine-like ligands ( $\mathrm{L}=$ 4-hydroxy-8-methyl-1,5-naphthyridine-3-carbonitrile 260, $\mathrm{X}=\mathrm{H}, \mathrm{Y}=\mathrm{CN}, \mathrm{Z}=\mathrm{CH}_{3}$ ) and 
an alkali metal ion $(\mathrm{A}=\mathrm{Na}, \mathrm{K}, \mathrm{Rb}, \mathrm{Cs}) 262$ were synthesized and characterized (Scheme 105) [122]. Not only transition metals, but also non-transition metals have been used for the preparation of 1,5-naphthyridine complexes. The hydroboration of 1,5-naphthyridine-based precursor 263 (Scheme 106) with 9H-9-borabicyclo[3.3.1]nonane (9H-BBN) afforded $\pi$-conjugated $\mathrm{N} \rightarrow \mathrm{B}$-ladder borane 264 [123].

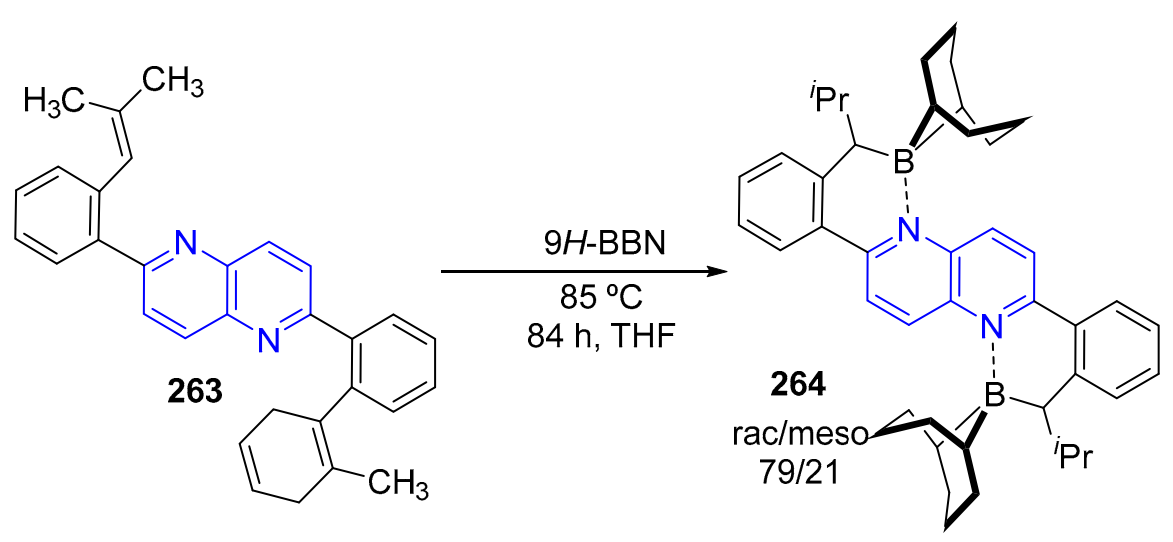

Scheme 106. Hydroboration reaction of 1,5-napthyridines to obtain borane 264 .

Boron-dipyrromethene (BODIPY) derivatives containing a naphthyridine ring were designed from 8-(4-formylaryl)-2-methoxynaphthyridine 265 in high yield. A Knoevenagel reaction was done with 2,4-dimethylpyrrole 266 followed by treatment with $\mathrm{BF}_{3} \cdot \mathrm{Et}_{2} \mathrm{O}$ to produce BODIPY compound 267. Further functionalization of the pyrrole rings may afford new BODIPY derivatives (Scheme 107) [95].<smiles>CCOC(=O)c1cnc2ccc(OC)nc2c1-c1ccc(C=O)cc1F</smiles>

i)<smiles>Cc1cc(C)c([18OH])[nH]1</smiles>

ii) Tetrachlorobenzoquinone $\mathrm{BF}_{3} \cdot \mathrm{Et}_{2} \mathrm{O}$<smiles></smiles>

267

Scheme 107. Preparation of BODIPY derivative 267.

Some research groups were involved in the study of group III metal chelates from 4-hydroxy-1,5-naphthyridine derivatives. Chen, $\mathrm{Wu}$ et al. reported the synthesis of aluminium, gallium and indium chelates of 4-hydroxy-1,5-naphthyridines 269 (Scheme 108) [31]. Due to the differing reactivity of the metal starting materials and the different solubility of the metal chelate products, various reaction conditions and the isolation/purification method were adopted in the final metal chelation reactions, and aluminium triisopropoxide, gallium chloride and indium chloride were used for the introduction of metals.

On the other hand, Wang et al. reported the DFT/B3LYP/6-31G(d) and TD-DFT calculations for the theoretical generation of group III metal chelates of 4-hydroxy-8-methyl-1,5-naphthyridine [124]. Calculation results are consistent with the experimental data previously reported by Chen, Wu et al. One year later, Lee et al. published another theoretical study with aluminium chelates of 4-hydroxy1,5-naphthyridines [125]. 


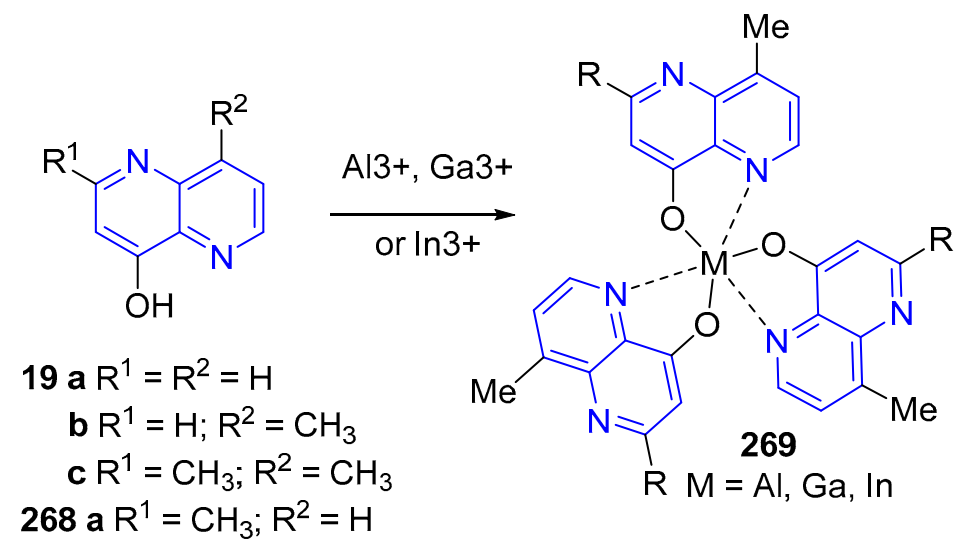

Scheme 108. Synthesis of aluminium, gallium and indium complexes 269.

\section{Properties of 1,5-Naphthyridines}

The aromaticity of 1,5-naphthyridine ring has been studied with magnetic criteria, magnetic susceptibility isotropic and nucleus-independent chemical shifts (NICS), calculated at the BLYP/6-31G(d) level of theory. According to this study, the magnetic susceptibility and not NICS is a reliable criteria in their case [126]. In another study, the aromaticity of quinolines, naphthyridines and phenanthrolines was evaluated [59]. According to the results, quinoline is the most aromatic substrate, followed by naphthyridine and then phenanthroline, and substantial influence of the position of the nitrogen atoms of the (poly)aromatic compounds protonation reaction was observed. Recently, stacking interactions involving Asp-Arg and Glu-Arg salt-bridges with aromatic 1,5-naphthyridines have been studied using robust ab initio methods. The guanidinium of Arg is consistently positioned, such that two nitrogen atoms are located above the ring centroids and the salt-bridge dipole is aligned with the electric field above the ring [127].

These heterocyclic compounds could be considered as organic hydrogen carriers. A high level ab initio quantum chemistry calculations suggested that the release of $\mathrm{H}_{2}$ (when passing from aromatic 1,5-naphthyiridine to perhydro-1,5-naphthyiridine) was greatly favored thermodynamically and the corresponding perhydro nitrogenated heterocycles possess high hydrogen storage capacity [128]. The 1,5-naphthyridine compound $\mathbf{2 a}$ (previously prepared, vide supra, Scheme 1) exhibits $3.64 \mathrm{kcal} \mathrm{mol}^{-1}$ and spontaneously dehydrogenates (Scheme 109).<smiles>c1cnc2cccnc2c1</smiles>

2a<smiles>[SbH3]=Cc1ccccc1</smiles>

$-5 \mathrm{H}_{2}$<smiles>O=C1CCCNC1CCCNC1CCCCC1</smiles>

Scheme 109. 1,5-Naphthyridine as organic hydrogen carrier.

DFT calculations have been also applied to calculate proton affinities, polarizabilities, and some ionization energies and atomic and ring neutral bond orbital (NBO) for some polycyclic aromatic nitrogen heterocyclics (PANHs), including 1,5-naphthyridine [129]. In 1,5-naphthyridines, which contain two-nitrogen atoms in their skeleton, the charge delocalization weakens the mutual effects of the nitrogens and therefor the proton affinities decrease.

Static quantum chemical calculations and first principles molecular dynamics (FPMD) simulations were used to examine the behavior of 1,5-naphthyridine-2,6-diol, which indicated that the $\mathrm{N}-\mathrm{H}$ interactions were sufficiently strong to induce proton transfer processes that caused this molecular species to exist preferentially as a single layer [130]. 
In addition, in some other theoretical studies the molecular recognition was predicted by the hydrogen bonding (HB) in order to design biologically active molecules. In this case, 1,5-naphthyridine showed HB basicity of nitrogen lower than the measured values for quinoline and isoquinoline [131].

Hexadecane/water and 1-octanol/water partition coefficients have been measured for 1,5naphthyridine ring and $\Delta \log P$ values have been determined to be derived for a number of hydrogen bond acceptors that are neutral under normal physiological conditions. It has been shown that minimized electrostatic potential is a useful descriptor to predict the contribution of hydrogen bond acceptors to $\Delta \log P$ [132].

On the other hand, theoretical studies of the tautomerism of 4,8-dioxygenated 1,5-naphthyridine have been done in the gas phase and solution phase using polarisable continuum method at the B3LYP/6-311++G level [133]. In the gas phase all 271 form were more stable than the others $(271>273>272)$. With increasing polarity, total energy of all compounds were more negative. The charges on all five positions were affected by substituents and solvents. In addition, a regular variation was found with increasing of dielectric constant (Scheme 110).<smiles>[R]c1c[nH]c2c(=O)cc[nH]c2c1=O</smiles><smiles>[R]c1c[nH]c2c(O)ccnc2c1=O</smiles><smiles>[R]c1cnc2c(O)ccnc2c1O</smiles>

Scheme 110. Theoretical tautomeric studies of 4,8-dioxygenated 1,5-naphthyridines.

\section{Applications of 1,5-Naphthyridines}

Along with the synthesis of 1,5-naphthyridines indicated in previous sections, a wide range of applications has been reported many of them being related to the biological activity of the compounds and others to their physical properties.

\subsection{Biological Activity}

Among the biological activities reported for 1,5-naphthyiridine derivatives antiproliferative, antibacterial, antiparasitic, antiviral properties, in most cases enzyme inhibitor, anti-inflammatory activity or influence on the cardiovascular or central nervous system (CNS) diseases have been to mentioned.

\subsubsection{Antiproliferative Activity}

1,5-Naphthyridine 275 (Figure 6) prepared by a fragment-based drug discovery (FBDD) approach as an analogue of lead compound $\mathbf{2 7 4}$, showed not only micromolar $\mathrm{IC}_{50}$ values $(\sim 82 \mu \mathrm{M})$ as Rpn11-selective inhibitor (proteasome inhibitor) but also presented also cytotoxicity toward cancer cell lines [34]. Inhibition of Rpn11 may lead to preferential apoptosis of neoplastic cells because these cells are thought to have a higher dependency on proteasome-dependent protein quality control compared to normal cells.

Significantly, protein kinases are one of the most targeted group; some kinase inhibitors have been approved by FDA for treatment of cancer. In 2004 Gellibert et al. reported the selectivity of 1,5-naphthyridine derivatives against p38 MAP kinase. In this case, 1,5-naphthyridin-4-yl-substituted aminothiazoles, such as compound $\mathbf{2 7 6}$ in Figure 7, and pyrazoles showed potent inhibition of ALK5 on both the enzyme and the TGF- $\alpha$-dependent cellular assays. Transforming growth factor (TGF- $\alpha$ ) is a pluripotent cytokine involved in a variety of biological processes such as development, cell growth, differentiation, cell adhesion, migration, extracellular matrix deposition, fibrosis and immune response regulation. Indeed, TGF- $\alpha$ overexpression has been implicated in multiple disease states including 
pulmonary fibrosis, liver fibrosis, renal glomerulosclerosis, and cancer [15]. Also a pyrazol substituted 1,5-naphthyridine showed inhibition of ALK5 on the TGF- $\beta$ type I receptor [134].<smiles>Sc1ccnc2ccccc12</smiles>

274<smiles>O=C(NCCc1nccs1)c1cnc2c(S)ccnc2c1</smiles>

\section{5}

$$
\mathrm{IC}_{50}(\mathrm{Rpn} 11)=0.39 \mu \mathrm{M} \quad \mathrm{IC}_{50}(\mathrm{Rpn} 11)=82 \mu \mathrm{M}
$$

Figure 6. Inhibition of Rpn11.

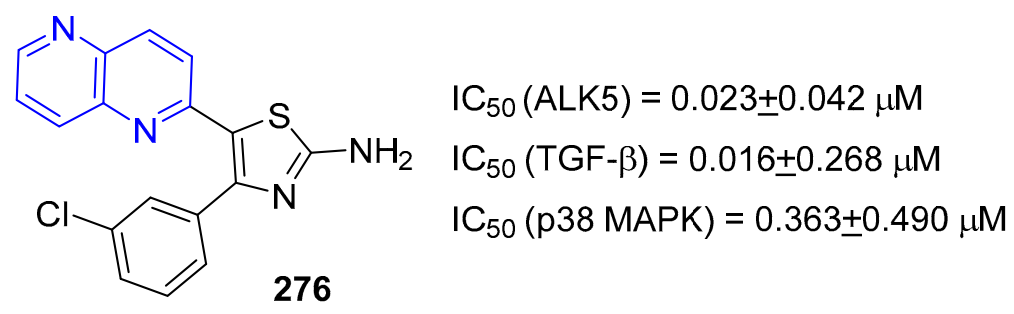

Figure 7. Inhibition of ALK5, on enzyme and TGF- $\alpha$-dependent cells.

In 2011, Nishimura et al. prepared 1,5-naphthyridine derivative 144 (previously prepared, vide supra, Scheme 62) and studied the PI3K $\alpha$ inhibitory activity and determined the $\mathrm{IC}_{50}$ values using U-87 MG human brain cells (Figure 8) [73]. Therapeutics targeting the PI3K pathway may have utility for the treatment of cancer, since this target plays an important role in cell growth and survival and it is dysregulated in many human cancers. Even the 1,5-naphthyridine derivative $\mathbf{1 4 4}$ shows a good enzyme inhibitory activity (Ki value $<10 \mathrm{nM}$ ) they decided not to focuse on this scaffold because the additional nitrogen at position 5 seemed not to offer significant advantages over quinolines.

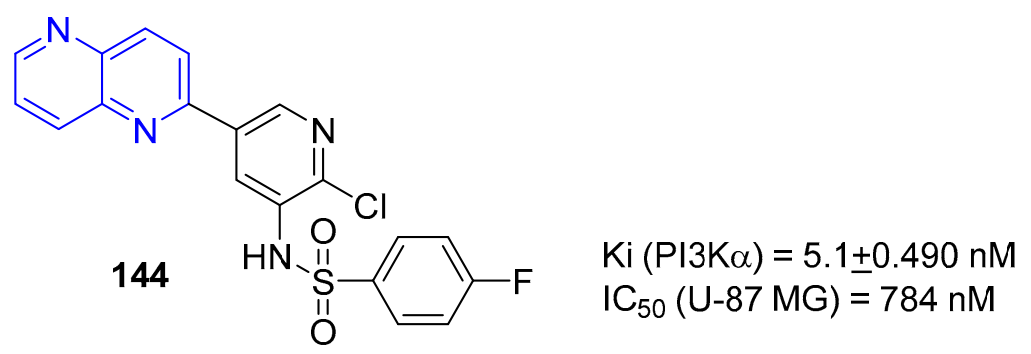

Figure 8 . PI3K $\alpha$ inhibitory activity and cytotoxicity on U-87 MG cells.

In 2014, new chemical entities of biological interest, such as 7-aryl-1,5-naphthyridin-4-ylureas appeared showing excellent inhibitory activities toward Aurora kinases A and B for the treatment of malignant diseases based on pathological cell proliferation [32]. In this study, the most active compound, 1-cyclopropyl-3-[7-(1-methyl-1H-pyrazol-4-yl)-1,5-naphthyridin-4-yl]urea 277 (Figure 9), displayed $\mathrm{IC}_{50}$ values of 107 and $13 \mathrm{nM}$ against Aurora kinases $\mathrm{A}$, and $\mathrm{B}$, respectively. However, the compound showed low antiproliferative activity when tested toward tumor cell lines. Then, this group considered modifying the position of the urea appendage on 1,5-naphthyridine ring from position 4 to 2 obtaining the 7-aryl-1,5-naphthyridin-2-ylureas, as compound 278 (Figure 9) [10]. This modification maintained inhibition of the Aurora B kinase, but also led to the inhibition of the Raf/MEK/ERK signaling pathway. In this sense, several analogues were active at micromolar and submicromolar range against ERK2 and Aurora B, associated with very promising antiproliferative activity. 


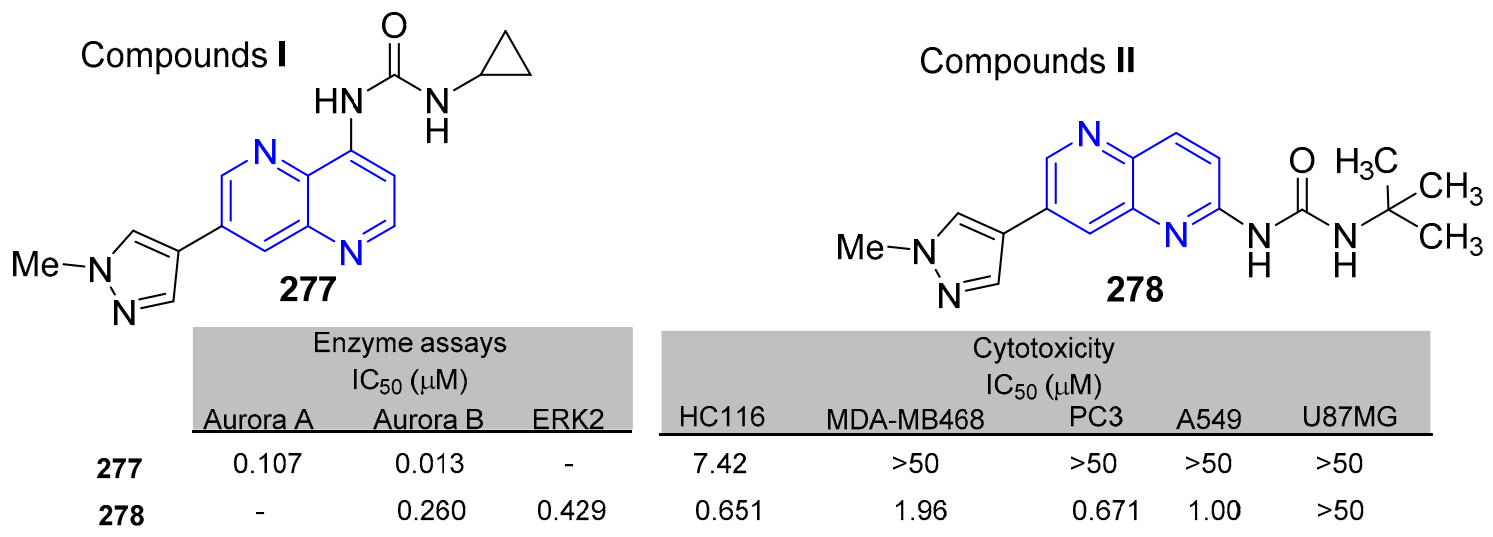

Figure 9. Biological activity on Aurora kinases A and B and cytotoxicity values.

The compound MK-2461 was developed by Merck and identified as an ATP-competitive c-Met inhibitor. C-Met is the high affinity receptor tyrosine kinase (RTK) that binds with the hepatocyte growth factor (HGF). Based on scaffold Wu et al. reported the synthesis and biological study of a series of 1,5-naphthyridine derivatives 279 in which the heptatomic ring is omitted compared with MK-2461 (Figure 10) [9]. The compounds were tested at a single concentration of $10 \mu \mathrm{M}$ and defined as effective inhibiting over half of the c-Met kinase at that concentration. Noteworthy, compound 279 with a cyclopropyl group proved to by the most active presenting the highest (74.6\%) inhibition of c-Met kinase. In addition, compounds were also tested in vitro for anti-tumor activities against cervix (Hela) and lung (A549) human cancer cell lines.

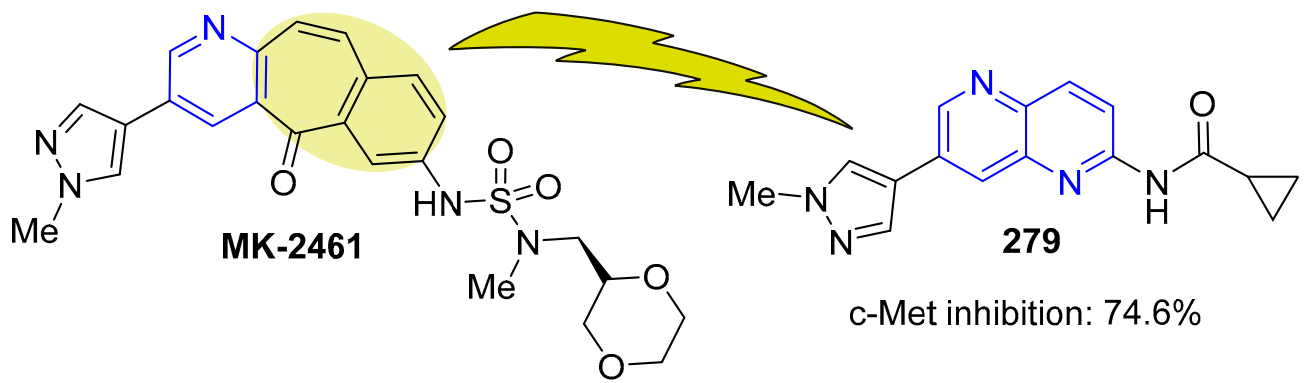

Figure 10. Inhibition of c-Met kinase activity.

In 2013, orally bioavailable amide substituted 1,5-naphthyridines, as compound 206 (previously prepared, vide supra, Scheme 84), were reported as potent and selective tankyrase inhibitors (Figure 11). The inhibition of tankyrase may reduce the levels of $\beta$-catenin-mediated transcription and inhibit tumorigenesis, offering a novel approach towards the treatment of colorectal cancer. In order to further improve the potency via the H-bond donor properties of the hydrogen at position 2, naphthyridine derivative 207a $(\mathrm{R}=\mathrm{H})$ was prepared. Although, improved enzyme and cellular potency, but poor oral exposure in mice, were achieved. Further blocking the sites of potential oxidative metabolism yielded fluorinated analogue $\mathbf{2 0 7 b}(\mathrm{R}=\mathrm{F})$, which featured retained potency, with improved solubility and improvements in oral exposure (Figure 11) [102].

DNA topoisomerases unravel turns in DNA that occur as a result of DNA transcription and replication. A series of 4-phenyl-1,5-naphthyridines derivatives exhibited inhibitory effect on topoisomerase I comparable to those observed for the natural inhibitor camptothecin (CPT), and it was the first time that simple 1,5-naphthyridines were tested as topoisomerase I inhibitors [45]. Among the prepared derivatives, aromatized naphthyridines were selected for the evaluation of their therapeutic effect against a human colon cancer cell line (COLO205). The fluorinated derivative $\mathbf{2 8 0}$ (Figure 12) was the most cytotoxic, showing good enzyme inhibition and $\mathrm{IC}_{50}$ values close to $\mathrm{CPT}$. 
<smiles>CC1(C)OC(=O)N(c2ccc(C(=O)Nc3ccnc4cccnc34)cc2)[C@H]1c1ccccc1</smiles>

206<smiles></smiles>

207 a $\mathrm{R}=\mathrm{H}$ b $R=F$

\begin{tabular}{|c|c|c|c|}
\hline & $\begin{array}{c}\text { TNKS1 } \\
I_{50}(\mu \mathrm{M}) \\
\end{array}$ & $\begin{array}{c}\text { SW480 } \\
\beta \text {-catenin } \\
\mathrm{IC}_{50}(\mu \mathrm{M})\end{array}$ & $\begin{array}{c}\text { Axin } \\
\mathrm{EC}_{50}(\mu \mathrm{M})\end{array}$ \\
\hline 0 & 0.018 & 0.189 & 1.01 \\
\hline 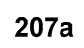 & 0.004 & 0.073 & 0.23 \\
\hline & 0.004 & 0.271 & 0.19 \\
\hline
\end{tabular}

Figure 11. Inhibition of tankyrase activity.

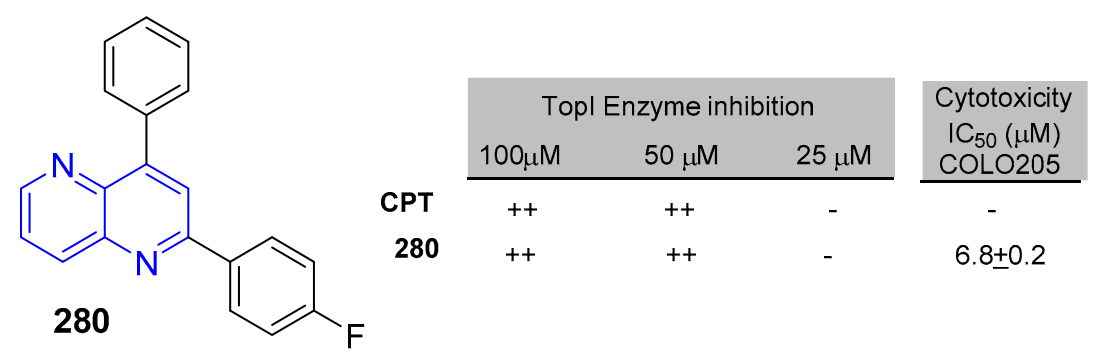

Figure 12. Inhibition of topoisomerase I activity.

One point for the effectiveness of cancer therapy depends on the evolution of DNA in the cell. Therefore, those compounds that can directly affect DNA, its replication or repair, are very interesting in the treatment of cancer. In 2009, a nitroimidazol 1,5-naphthyridine hydrochloride derivative 281 (Figure 13) was synthesized and evaluated as DNA binder and its cytotoxicity, radiosensitization and interaction with chemotherapeutic agents studied. Despite this compound did not show DNA-binding activity and resulted less potent hypoxic cytotoxins than weak DNA-intercalative bioreductives, it can still show good hypoxic selectivity values and interact with radiation/chemoterapeutic agents [18].<smiles>O=[N+]([O-])c1nccn1CCCNc1ccnc2cccnc12</smiles>

$$
\begin{aligned}
& I C_{50}(V 79)=981.1 \pm 18.9 \mu \mathrm{M} \\
& I C_{50}(A 549)=1490.2 \pm 178.6 \mu \mathrm{M}
\end{aligned}
$$

281

Figure 13. Cytotoxicity against cancer cells.

Rajković et al. in 2018 synthesized new 1,5-naphthyridine-bridged (1,5-nphe) dinuclear platinum(II) complexes, with the general formula $[\{\mathrm{Pt}(\mathrm{L}) \mathrm{Cl}\} 2(\mu-1,5-\mathrm{nphe})]\left(\mathrm{ClO}_{4}\right)_{2}$, and evaluated the in vitro cytotoxic activity of these complexes against three tumor cell lines, murine colon carcinoma (CT26), murine mammary carcinoma (4T1) and murine lung cancer (LLC1) and two normal cell lines, murine mesenchymal stem cells (MSC) and human fibroblast (MRC-5) cells [135].

\subsubsection{Antibacterial and Antifungal Activity}

Regarding antibacterial activity, macrolide antibiotics with a 1,5-naphthyridine core in their structure present some improvements with resistant respiratory pathogens for the treatment of 
community-acquired infections [12]. The best results were obtained for the 3-hydroxy-1,5-naphthyridine analogue 219 (previously prepared, vide supra, Scheme 89). This compound is differentiate from telithromycin $\mathbf{2 8 2}$ in both hepatic microsomal extraction ratio and CYP3A time-dependent inactivation, mantaining preclinical in vivo efficacy (Figure 14).

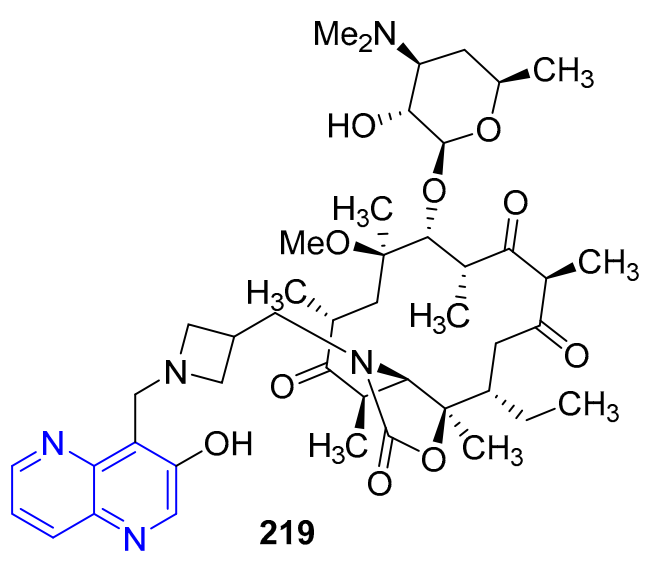

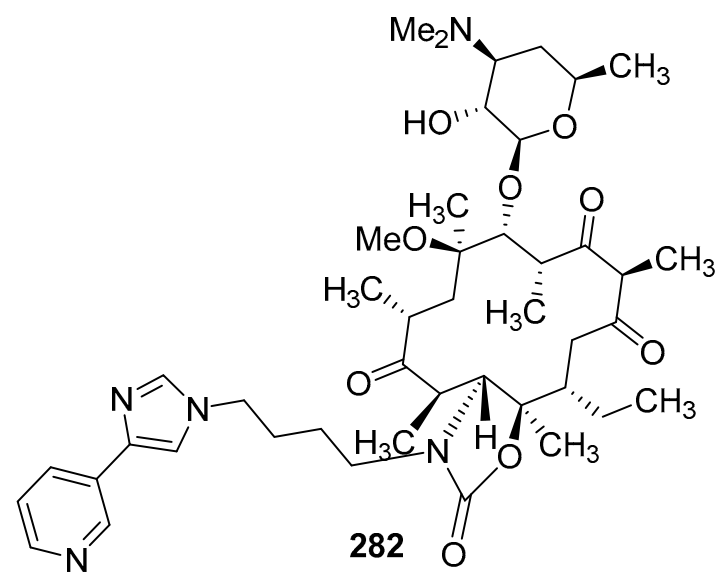

\begin{tabular}{cccccc}
\multicolumn{2}{c}{$\begin{array}{c}\text { S. pneumoniae } 1016 \\
\text { MIC }(\mu \mathrm{g} / \mathrm{mL})\end{array}$} & $\begin{array}{c}\text { S. pneumoniae } 1095 \\
\mathrm{MIC}(\mu \mathrm{g} / \mathrm{mL})\end{array}$ & $\begin{array}{c}\text { S. pneumoniae } 1175 \\
\mathrm{MIC}(\mu \mathrm{g} / \mathrm{mL})\end{array}$ & $\begin{array}{c}\text { S. pyogenes } 1079 \\
\mathrm{MIC}(\mu \mathrm{g} / \mathrm{mL})\end{array}$ & $\begin{array}{c}H \text {. influenzae } 1325 \\
\mathrm{MIC}(\mu \mathrm{g} / \mathrm{mL})\end{array}$ \\
\hline $\mathbf{2 1 9}$ & $\leqslant 0.06$ & $\leqslant 0.06$ & $\leqslant 0.06$ & 32 & 4 \\
$\mathbf{2 8 2}$ & $\leqslant 0.06$ & $\leqslant 0.06$ & $\leqslant 0.06$ & 0.5 & 4
\end{tabular}

Figure 14. Antibacterial activity of 1,5-naphthyridine-containing macrolides.

The development of new therapies against methicillin-resistant Staphylococcus aureus (MRSA) is needed to counteract the significant threat that MRSA presents to human health. In this regard, 1,5-naphthyridine derivatives have been evaluated as antibacterial agents against methicillin-sensitive and methicillin-resistant $S$. aureus and vancomycin-sensitive and vancomycin-resistant Enterococcus faecalis. While aminomethyl derivative 197a (previously prepared, vide supra, Scheme 80) did not exhibit significant antibacterial activity, the guanidinomethyl derivative 197b showed more pronounced antibacterial activity. (Figure 15) [98].

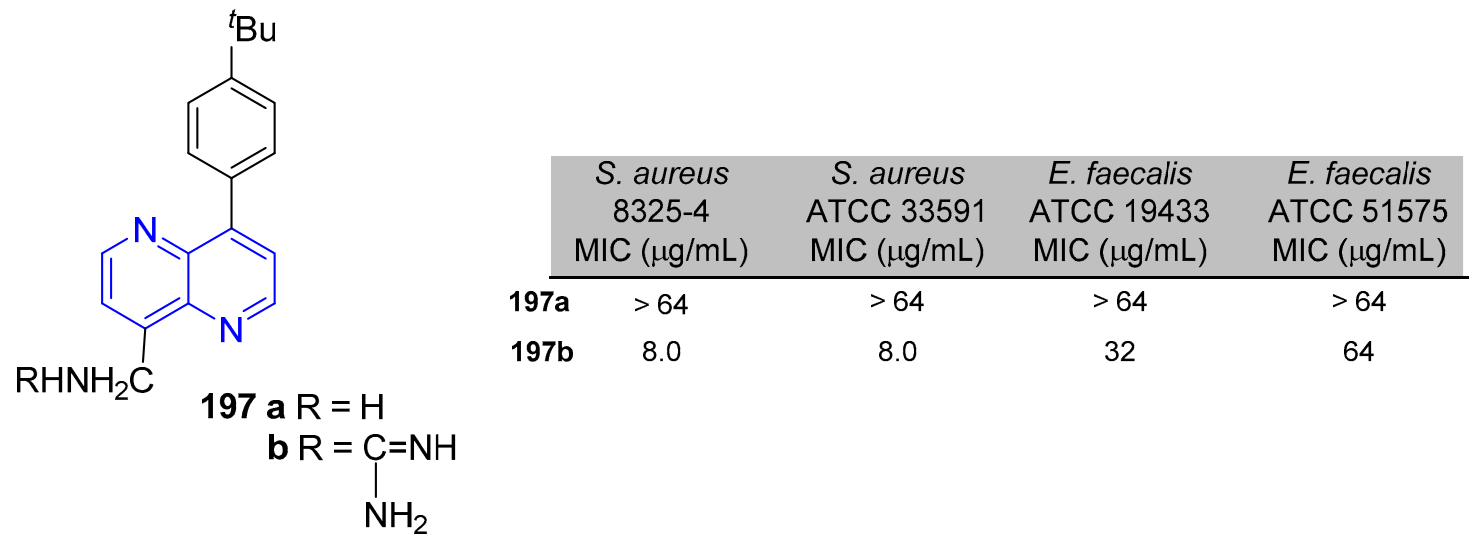

Figure 15. Antibacterial activity of some 1,5-naphthyridines against drug-sentsitive and drug-resistant bacteria.

Antibacterial activity of a 1,5-naphthyridines with chromium metal ion and oxalic acid has been evaluated by testing their antagonistic effect against Gram-positive bacteria, Enterococcus faecalis, Staphylococcus aureus, Listeria innocua; and Gram-negative species Shigella flexneri, Escherichia coli, 
Salmonella enterica and Pseudomonas aeruginosa [107]. Antibacterial study confirmed that the 1,5-naphthyridine ligand is biologically active against Gram-negative S. enterica bacteria and the chromium(III) complex showed enhanced activity against L. innocua, P. aeruginosa, and E. coli upon coordination. The free 1,5-naphthyridine ligand was found to be biologically inactive against $S$. flexneri and E. faecalis bacteria. The coordination of this ligand with the anionic chromium (III) moiety induced appreciable antimicrobial activities against the Gram-negative S. enterica bacteria but not towards the Gram-positive S. aureus bacteria.

The antimicrobial efficiency of polynuclear silver(I) complexes with 1,5-naphthyridine 283-285 was evaluated against the broad panel of Gram-positive and Gram-negative bacteria and fungi (Figure 16) [116]. The complexes showed good to moderate antibacterial activity with the minimal inhibitory concentration (MIC) values being in the range $12.5-100 \mu \mathrm{g} / \mathrm{mL}$, while their antifungal activity against the investigated Candida spp. was significantly higher (MIC $=0.78-6.25 \mu \mathrm{g} / \mathrm{mL}$, Figure 16). Moreover, complexes $\mathbf{2 8 3}$ and $\mathbf{2 8 4}$ effectively inhibited Candida albicans biofilms formation, while $\mathbf{2 8 3}$ also inhibited the formation of mixed Candida albicans/Pseudomonas aeruginosa biofilms. Toxicological evaluations on zebrafish (Danio rerio) embryos revealed that all silver(I) complexes could be applied as antifungal agents, whereas $\mathbf{2 8 5}$ had the best therapeutic potential showing both the lowest MIC values against the tested Candida strains and the non-toxic in vivo response in the zebrafish embryos at these doses.
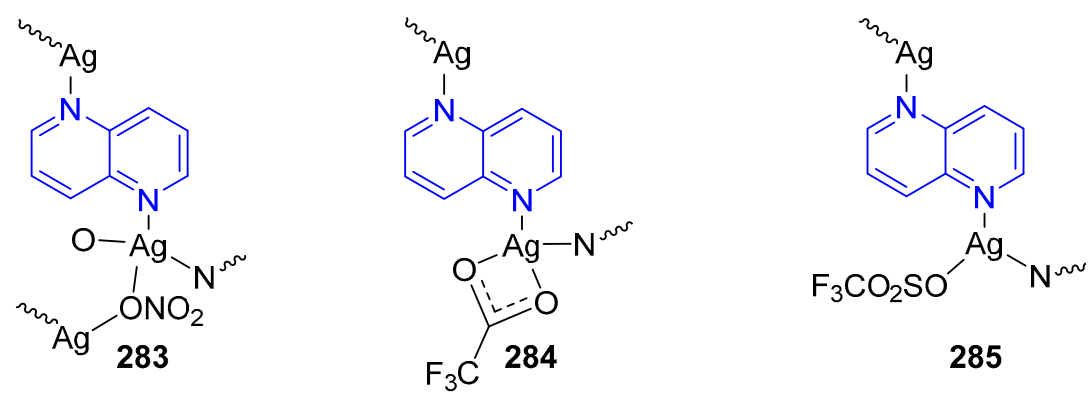

\begin{tabular}{|c|c|c|c|c|c|c|c|c|c|}
\hline \multicolumn{10}{|c|}{$\operatorname{MICs}(\mu \mathrm{g} / \mathrm{mL})$} \\
\hline & $\begin{array}{c}\text { C. } \\
\text { albicans }\end{array}$ & $\begin{array}{c}\text { C. } \\
\text { parapsilosis }\end{array}$ & $\begin{array}{c}\text { C. } \\
\text { krusei }\end{array}$ & $\begin{array}{c}\text { C. } \\
\text { glabrata }\end{array}$ & $\begin{array}{c}P . \\
\text { aeruginosa }\end{array}$ & $\begin{array}{c}\text { S. } \\
\text { aureus }\end{array}$ & $\begin{array}{c}B . \\
\text { subtilis }\end{array}$ & $\begin{array}{l}\text { E. } \\
\text { coli }\end{array}$ & $\begin{array}{c}\text { K. } \\
\text { pneumoniae }\end{array}$ \\
\hline 283 & 3.1 & 6.25 & 0.78 & 3.1 & 25 & 50 & 12.5 & 25 & 100 \\
\hline 284 & 3.1 & 3.1 & 1.56 & 1.25 & 25 & 50 & 25 & 12.5 & 100 \\
\hline 285 & 1.25 & 2.5 & 1.25 & 1.25 & 25 & 25 & 25 & 12.5 & 50 \\
\hline
\end{tabular}

Figure 16. Antibacterial activity of silver complexes.

Novel bacterial topoisomerase inhibitors (NBTIs) are new class of broad-spectrum antibacterial agents targeting bacterial DNA gyrase and topoisomerase IV at a site distinct from quinoline binding. Bicyclic aromatic 1,5-naphthyridine derivatives linked to a tetrahydropyran (THP) ring through a syn-diol linker showed potent anti-Gram-positive activity [65]. For instance, compound 286 was found to be a dual DNA gyrase-topoisomerase IV inhibitor with broad antibacterial activity and low propensity for spontaneous resistance development, but suffered from high hERG $\mathrm{K}^{+}$ channel block (Figure 17). On the other hand, analog 287 displayed lower hERG K ${ }^{+}$channel block, while retaining potent in vitro antibacterial activity and acceptable frequency for resistance development. Furthermore, 1,5-naphthyridine 287 showed moderate clearance in rat and promising in vivo efficacy against Staphylococcus aureus in a murine infection model. These THP-naphthyridine-based bacterial topoisomerase inhibitors display promising properties and deserve further efforts to be eventually transformed into new clinically used antibacterial agents. 
<smiles>COc1ccc2ncc(F)c([C@H](O)[C@H](O)[C@H]3CC[C@@H](NCc4ccc5c(n4)NC(=O)CS5)CO3)c2n1</smiles>

\begin{tabular}{ccccc}
\multicolumn{5}{c}{ MICs $(\mu \mathrm{g} / \mathrm{mL})$} \\
\hline $\begin{array}{c}\text { S. aureus } \\
\text { ATCC 29213 }\end{array}$ & $\begin{array}{c}\text { S. aureus } \\
\text { A-234 }\end{array}$ & $\begin{array}{c}\text { S. pneumoniae } \\
\text { ATCC 49619 }\end{array}$ & $\begin{array}{c}\text { Escherichia } \\
\text { coli }\end{array}$ \\
$\mathbf{2 8 6}$ & 0.03 & 0.25 & 0.006 & 1 \\
$\mathbf{2 8 7}$ & $<0.015$ & 2 & $<0.015$ & 8
\end{tabular}

Figure 17. Antibacterial activity of THP-naphthyridine derivatives.

Naphthyridine derivatives, whose structural features consist of three structural motifs: a left hand site bicyclic aromatic heterocycle (a 1,5-naphthyridine), a right hand side aromatic heterocycle connected by a 8-atom central linker (a oxabicyclooctane) placing a basic nitrogen at position 7 , present no cross-resistant to known antibiotics and therefore serve as excellent candidates to combat drug-resistant bacteria [25]. Singh et al. evaluated these compounds against a panel of key Gram-positive and Gram-negative strains of bacteria, as well as for hERG activity and for in vivo efficacy in murine model of Staphylococcus aureus infection. This type of compound, such as derivative 288, showed a potent broad-spectrum as antibacterials. NBTIs with reduced off-target activity (hERG $\left.\mathrm{IC}_{50}>18 \mu \mathrm{M}\right)$ and improved physical properties (Figure 18). On the other hand, hydroxyl substituted derivative 289 was bactericidal, selectively inhibited DNA synthesis, Staphylococcus aureus gyrase $\left(\mathrm{IC}_{50}=1.02 \mu \mathrm{M}\right)$ and topoisomerase IV $\left(\mathrm{IC}_{50}=10.4 \mu \mathrm{M}\right)$ and showed parenteral and oral efficacy $\left(\mathrm{ED}_{50}\right)$ at less than $2.5 \mathrm{mg} / \mathrm{kg}$ doses in a $S$. aureus murine infection model. In another studies, it was demostrated that substitutions on the other three carbons generally have detrimental effect on the activity, with no clear hERG activity [53,91]. In these cases, for example, compound 290, with a hydroxy propyl ether, retained the potency, spectrum and in vivo efficacy of $\mathbf{2 8 8}$ associated with the decreased hERG activity and improved physical property [104].

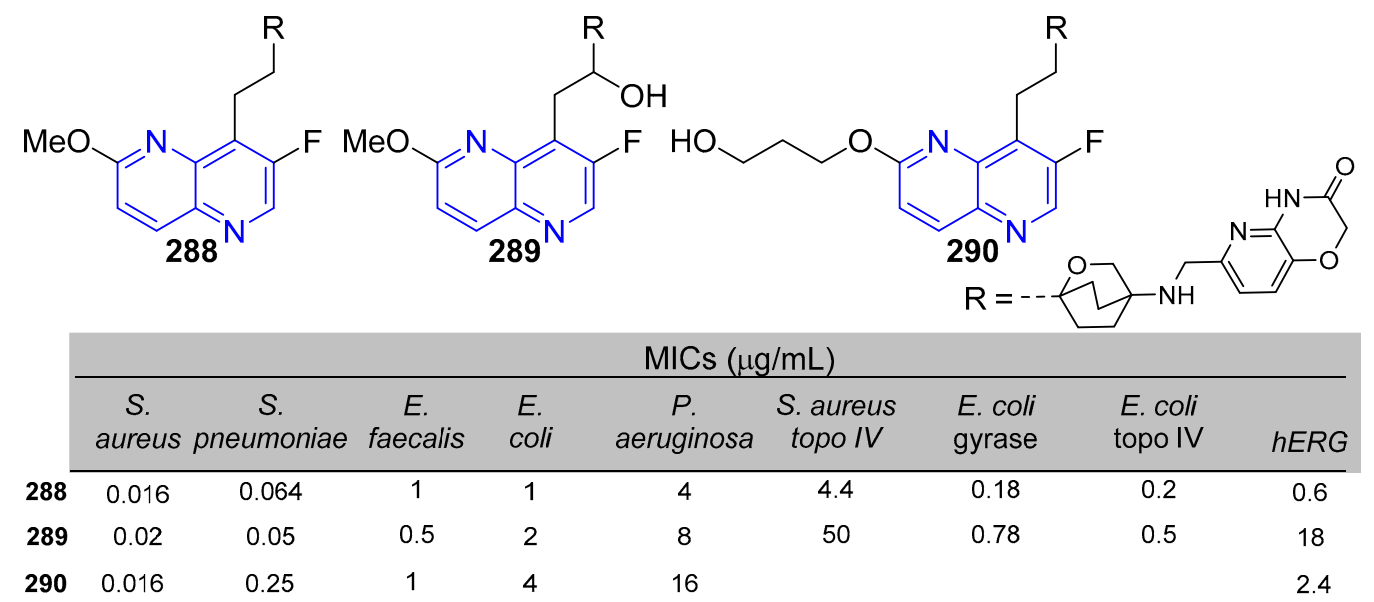

Figure 18. Broad-spectrum antibiotics containing a 1,5-naphthyridine core. 
Further studies for the development of bacterial topoisomerase inhibitors reported the synthesis of 1,5-naphthyridine dioxane-linked derivatives 291-296 (Figure 19) [96]. These compounds showed inhibitory activity on both gyrase and topoisomerase IV enzymes, demonstrating also improved antistaphylococcal activity and reduced hERG inhibition. Secondary amine derivatives bearing a monocyclic enzyme-binding moiety with a lipophilic para substituent possessed potent activity when tested against Staphylococcus aureus. Incorporation of a fluorinated naphthyridine DNA-binding motif robustly enhanced the antibacterial activity and topoisomerase IV inhibition of compounds 291-295 with minimal impact on the hERG profile. Dioxane-linked NBTIs thus offer opportunity to obtain and optimize novel therapeutics for treating antibiotic-resistant infections.

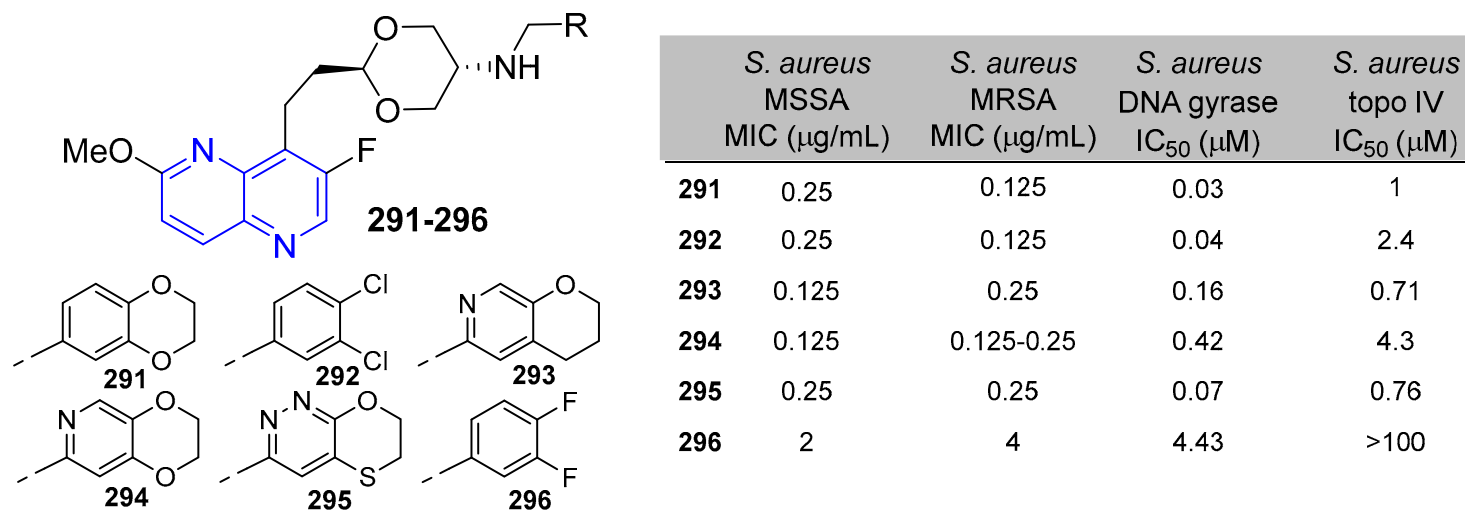

Figure 19. Antibacterial activity of dioxane-linked 1,5-naphthyridine derivatives.

\subsubsection{Antiparasitic Activity}

Malaria is a leading cause of mortality worldwide amongst infectious diseases. In 2007, 1,5naphthyridine derivatives $\mathbf{8 8 a}$ and $\mathbf{8 8 b}$ (previously prepared, vide supra, Scheme 32) were evaluated as antimalarial agents (Figure 20) [11]. Compounds showed lower toxicity than the parent compound primaquine (PQ), preserving the desired antimalarial activity. Some compounds exhibit a therapeutic index over 10 times superior to that of the commonly used antimalarial drug chloroquine (CQ).

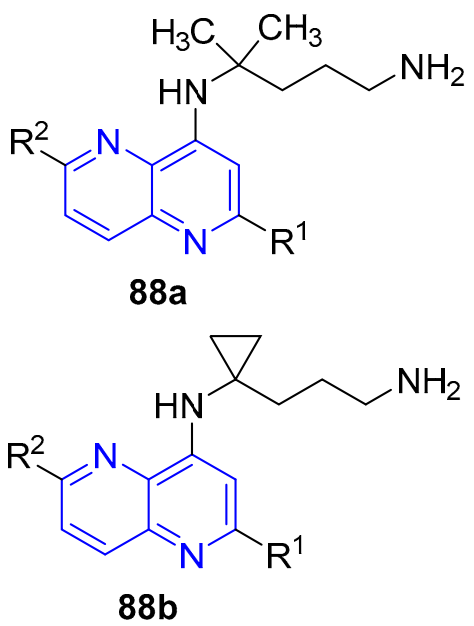

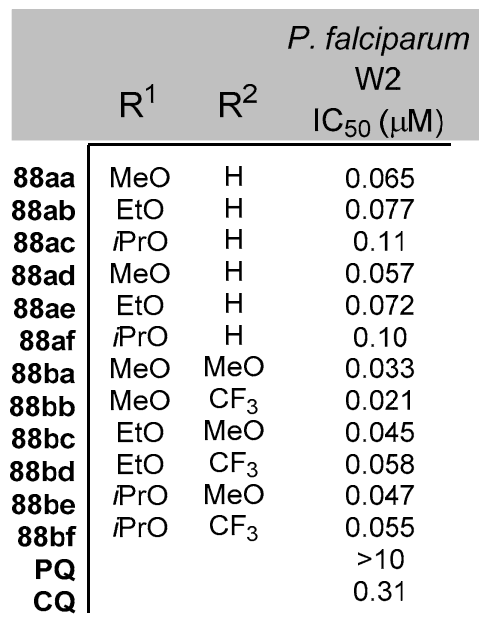

Figure 20. Evaluation of 1,5-naphthyridine-based molecules as antimalarial agents.

Later on, a series of 2,8-disubstituted-1,5-naphthyridine analogues were evaluated for in vitro antiplasmodial activity, as inhibitors of Plasmodium protein kinases (PKs) [35]. Several analogues exhibited low nanomolar activity against both chloroquine sensitive NF54 ( $\left.\mathrm{IC}_{50}<100 \mathrm{nM}\right)$ and multidrug resistant (K1) strains of the human malaria parasite Plasmodium falciparum. Compound 297 
showed improved bioavailability in mouse and was chosen for in vivo efficacy studies based on the pharmacokinetics and antiplasmodial activity (Figure 21). From a total of 48 analogues made for SAR investigation, 26 showed improved blood stage activity compared to the original hit. Several analogues exhibited low nanomolar activity $\left(\mathrm{IC}_{50}<100 \mathrm{nM}\right)$ and were equipotent against both NF54 and K1.

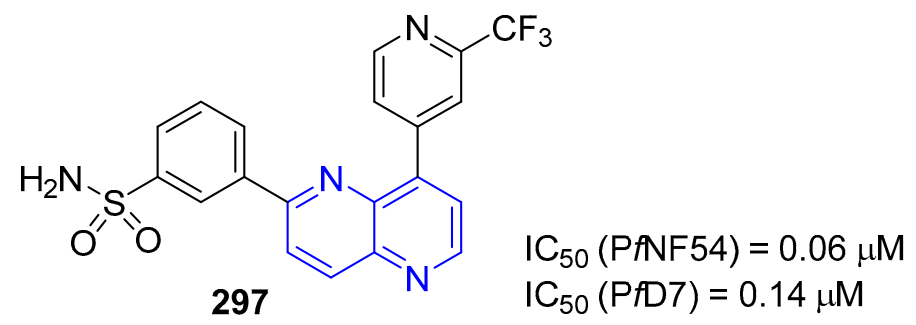

Figure 21. Evaluation of 1,5-naphthyridine-sulfonamides as antimalarial agents.

In order to identify inhibitors of Cryptosporidium FIKK (CpFIKK), a focused library of 2500 known kinases inhibitors was screened. FIKK kinases are expressed mostly during the blood stage of the Cryptosporidium species life cycle, as well as in the genomes of Plasmodium, Toxoplasma, Neospora and Eimeria [136]. Two compounds, with a 1,5-naphthyridine aminothiazole scaffold 298a and $\mathbf{2 9 8 b}$ showed potent inhibition of $\mathrm{CpFIKK}$ kinase, with $\mathrm{IC}_{50}=3 \mathrm{nM}$ and $0.2 \mathrm{nM}$, respectively (Figure 22) [101]. Moreover, compound 298b was identified both CpCDPK1 selective as well as dually acting CpFIKK-CDPK1 inhibitor and used at appropriate concentrations, which could serve as a useful in vitro tool for understanding the biological role of FIKK in C. parvum.<smiles>Nc1nc(Br)c(-c2ccc3ncccc3n2)s1</smiles>

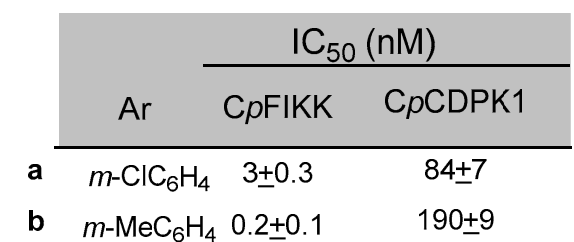

Figure 22. Inhibition of CPFIKK and CDPK1 kinases by a 1,5-naphthyridine aminothiazole derivative.

In 2018, a wide range of substituted 1,5-naphthyridines showed antileishmanial activity on promastigotes and amastigote-infected splenocytes of L. infantum [46]. These 1,5-naphthyridines displayed higher antiparasitic activity on intracellular amastigotes than on free-living promastigotes. And in particular, compound 299 demonstrated its high in vitro antileishmanial activity and low toxicity showing the highest selective inhibition $(\mathrm{SI})$ value of this family $(\mathrm{SI}=271.5)$ (Figure 23). Moreover, these derivatives inhibited leishmanial and human topoisomerase IB enzymatic activity.

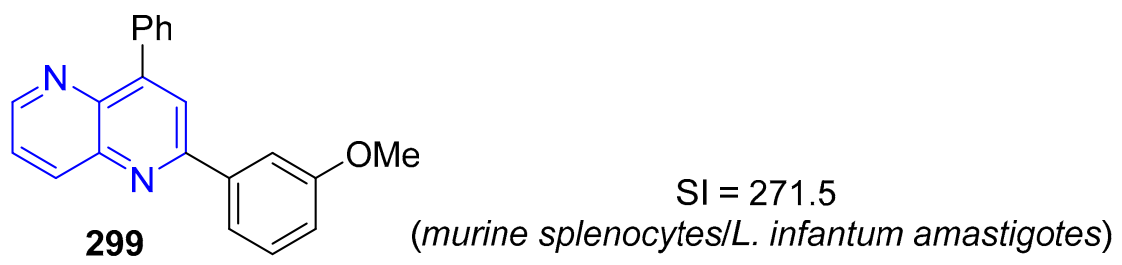

Figure 23. 1,5-Naphthyridine derivative with antileishmanial activity.

\subsubsection{Antiviral Activity}

Some 1,5-naphthyridine heterocyclic derivatives are of interest as antiviral agents. In 2009 a series of triazole-substituted 1,5-naphthyridine-3-carboxylic acids 300 (Figure 24) have been screened as HIV integrase inhibitors for the treatment of AIDS, even if potential inhibitory activities were not observed [22]. 
<smiles>[R]c1cccc(Cn2cc(COc3cc(-c4ccccc4)c4[nH]cc(C(=O)O)c(=O)c4n3)nn2)c1</smiles>

$$
\begin{aligned}
& \text { a } R=\mathrm{H} ; \mathbf{b} R=m-\mathrm{NO}_{2} \quad \text { HIV Integrase inhibition: less than } 50 \% \\
& \text { c } \mathrm{R}=o-\mathrm{Br} ; \mathbf{d} \mathrm{R}=p-\mathrm{Br} \\
& \mathbf{e} \mathrm{R}=0-\mathrm{CH}_{3} ; \mathbf{f} \mathrm{R}=m-\mathrm{CH}_{3} \\
& \mathbf{g} \mathrm{R}=p-\mathrm{CH}_{3} ; \mathbf{h} \mathrm{R}=0-\mathrm{F} \\
& \text { i } \mathrm{R}=m-\mathrm{F} ; \mathbf{j} \mathrm{R}=p-\mathrm{F} \\
& \mathbf{k} \mathrm{R}=p-\mathrm{NO}_{2}
\end{aligned}
$$

Figure 24. Inhibition of HIV integrase by triazole substituted 1,5-naphthyridine derivatives.

The Ebola virus (EBOV), considered a significant public health concern due its high fatality rate, can cause lethal acute hemorrhagic Ebola virus disease. There is currently no FDA-approved vaccine or medication to counter this disorder. In 2019, some aminoalkyl substituted 1,5-naphthyridines were described as anti-EBOV pharmacophores [27]. The naphthyridine inhibitors 301, 302 and 303 were found active in low-micromolar range (Figure 25). Furthermore, the envisioned naphthyridine derivatives have a structural similarity to the FDA approved antimalarial drug CQ, which was found to have moderate anti-EBOV activity.<smiles>CCN(CC)CCCNc1ccnc2c(NCCCN(CC)CC)ccnc12</smiles>

Figure 25. Anti-EBOV pharmacophores.

\subsubsection{Anti-inflammatory Activity}

In 2007, some 1,5-naphthyridinyl-oxazolidin-2-one derivatives, as compound 304, were studied as human CCR8 antagonist [137]. CCR8 may represent a potential target for treatment of asthma and other allergic diseases and it was demonstrated that CCR8 served as a co-receptor for diverse T-cell tropic, dual-tropic, and macrophage-tropic HIV-1 strains (Figure 26). 


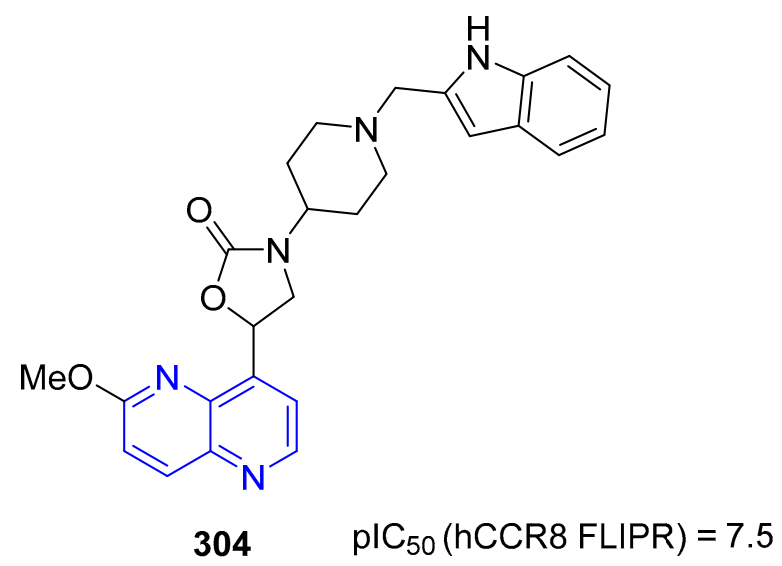

Figure 26. A human $\mathrm{CCR} 8$ antagonist. $\mathrm{pIC}_{50}$ value measure by a fluorometric imaging plate reader assay (FLIPR).

A series of naphthyridine derivatives 305 and 306 displayed bromodomain (BRD) and extra-terminal (BET) domain inhibition (Figure 27) [24]. The 1,5-naphthyridine derivatives with improved binding affinity relative to the 1,8- and 1,6-regioisomerswere found to be effective in a mouse model of inflammation. Cyclised analogues have good cell activity, good in vivo pharmacokinetics in rat associated with good solubility, making valuable scaffolds as bromodomain and extra-terminal (BET domain inhibitors. The best compounds were progressed in a mouse model of inflammation and exhibited dose-dependent anti-inflammatory pharmacology.

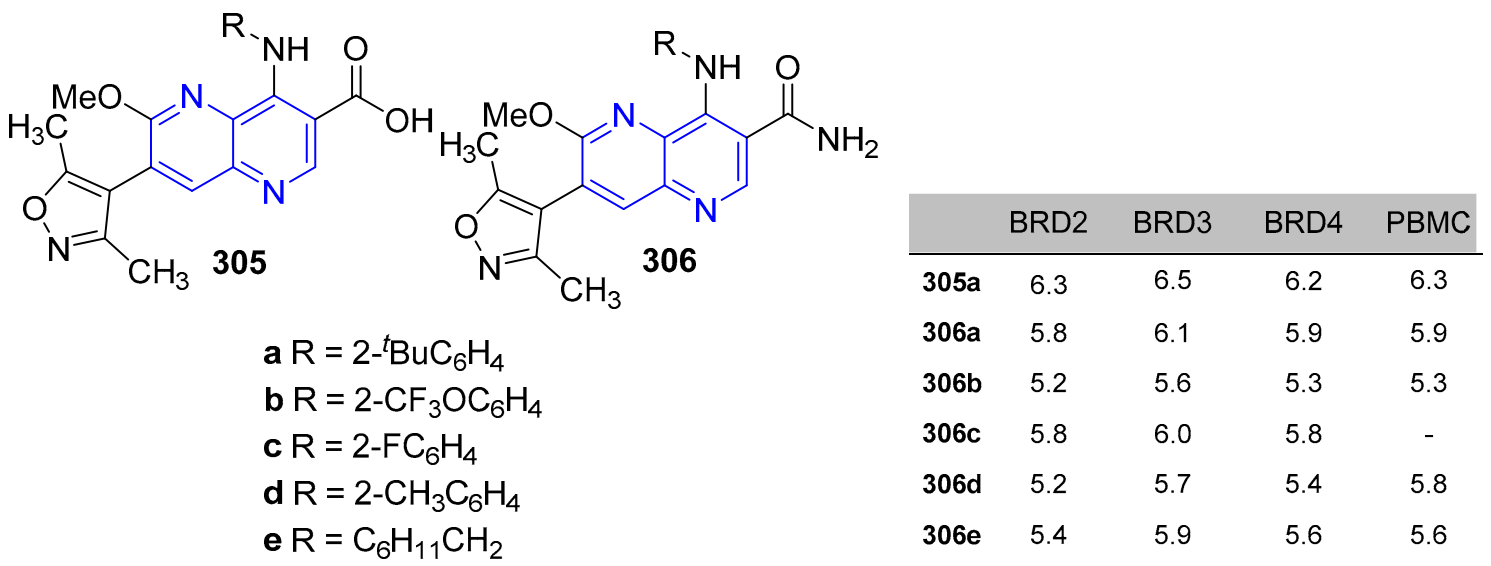

Figure 27. Inhibitors of bromodomain (BRD2-4) and peripheral blood mononuclear cells (PBMC) domain and their $\mathrm{pIC}_{50}$ values.

\subsubsection{Activity in Cardiovascular Diseases}

The in vitro activity as cholesterol ester transfer protein (CETP) inhibitors of some 1,5-tetrahydronaphthyridine derivatives 307, substituted at positions 2 and 5, has been studied by Fernandez et al. (Figure 28) [47]. In this work, it was also observed that these derivatives exhibited robust HDL-c elevation in vivo. The in vitro study in human plasma led to the identification of two compounds with good activity as CETP inhibitors important for the treatment of cardiovascular diseases.

A relationship has been observed between cardiovascular disease and hyperuricemia, hypertension, diabetes and renal disease. In 2016, in a study of a series of potent inhibitors of Human Uric Acid Transporter 1 (hURAT1), 1,5-naphthyridine was used as template. Unfortunately, the $\mathrm{IC}_{50}$ was quite $\operatorname{high}(>10 \mu \mathrm{M})[138]$. 


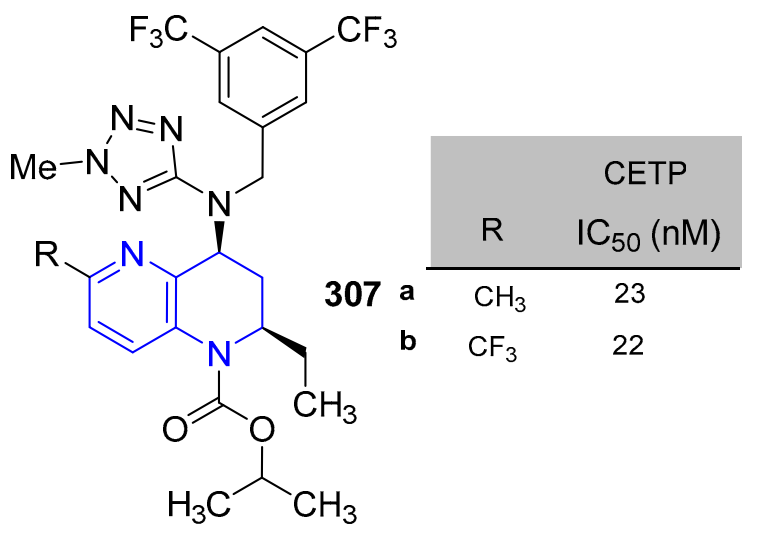

Figure 28. Inhibitors of CETP.

\subsubsection{Activity in Central Nervous System (CNS)}

Non-competitive metabotropic glutamate receptor 5 (mGluR5) antagonists are viewed as having promise against a number of CNS and peripheral diseases, including the treatment of pain, anxiety, gastro-esophageal reflux disease (GERD), Fragile X syndrome, and Parkinson's disease. In this regard, 1,5-naphthyridine derivatives $\mathbf{3 0 8}$ showed activity as receptor modulators, such as mGLuR5 antagonists. (Figure 29) [94].
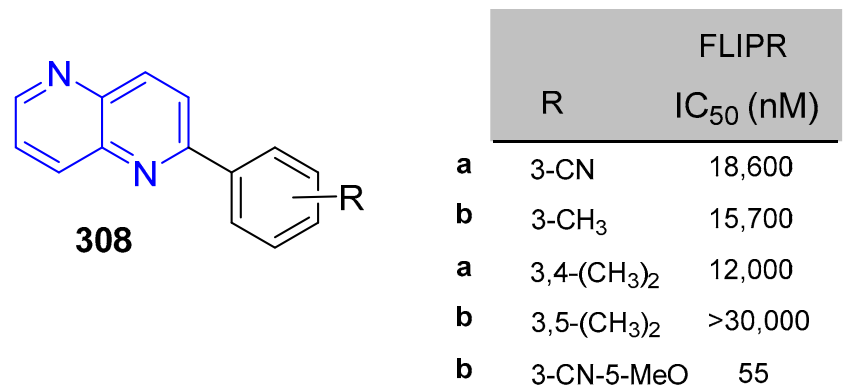

Figure 29. 1,5-Naphthyridine analogues as mGLuR5 antagonists. pIC 50 values measure by a fluorometric imaging plate reader assay (FLIPR).

On the other hand, 1,5-naphthyridine derivatives 223 (previously prepared, vide supra, Scheme 90), 225 (previously prepared, vide supra, Scheme 91) and $\mathbf{3 0 9}$ with urea substituents were studied as orexin-1 receptor antagonists (Figure 30) [105]. Orexin-expressing neurons are located predominantly in a small area in the hypothalamus and locus cerulean. However, the nerve fibers of orexin neurons project throughout the CNS, suggesting that orexins have multiple functions. In fact, the orexin system has already been shown to modulate a variety of important biological processes, including sleep/wake cycles, feeding, drug addiction and reward, as well as energy homeostasis.

In 2017, 1,5-naphthyridines showed an optimal pharmacokinetic profile as potent and selective binders to human Alzheimer disease (AD) aggregated tau, which implies them as potential tau PET tracer binders [38]. In certain neurodegenerative diseases, known as tauopathies, tau becomes detached from microtubules and forms insoluble aggregates in the brain. AD is characterized by plaques containing amyloid beta $(A \beta)$ and neurofibrillary tangles (NFTs) containing tau. In a radioligand filter binding assay and via displacement studies on human AD sections, compounds $\mathbf{3 1 0}$ and $\mathbf{3 1 1}$ were shown to be potent and selective tau aggregate binder (Figure 31). Based on these results, compound 311 has been selected for $[18 \mathrm{~F}]$ radiolabeling and PET imaging studies in different preclinical species. Neither off-target activity in a receptor panel and a kinase panel, nor MAO-A and MAO-B inhibitory activities were found. 
<smiles>Cc1nc2ccc(NC(=O)Nc3ccnc4cccnc34)cc2o1</smiles><smiles>CN(C)c1ccc(NC(=O)Nc2ccnc3cccnc23)cc1</smiles>

223
309

\begin{tabular}{ccc}
\multicolumn{3}{c}{ Ke $(n M)$} \\
\cline { 2 - 3 } & OX1 & OX2 \\
\cline { 2 - 3 } $\mathbf{2 2 5}$ & $45 \pm 12$ & 1194 \\
$\mathbf{3 0 9}$ & $>10,000$ & - \\
$\mathbf{2 2 3}$ & $46.3+8$ & $>10,000$
\end{tabular}

Figure 30. Orexin-1 receptor antagonists.<smiles>C=C=C</smiles>

310, HTS hit

Tau $\mathrm{K}_{\mathbf{i}}=13.9 \pm 1.8 \mathrm{nM}$

$\mathrm{A} \beta \mathrm{K}_{\mathrm{i}}=134 \pm 73 \mathrm{nM}$<smiles>Cc1cc(Nc2ccc3nc(F)ccc3n2)ccn1</smiles>

311, radiofluorination candidate Tau $\mathrm{K}_{\mathrm{i}}=7.9+2.5 \mathrm{nM}$ $\mathrm{A} \beta \mathrm{K}_{\mathrm{i}}>4300 \mathrm{nM}$

Figure 31. Selective tau aggregate binder.

\subsubsection{Activity in Hormonal Diseases}

In a recent study, a series of 1,5-naphthyridine derivatives for the chemical inhibition of dual specificity tyrosine-phosphorylation-regulated kinase 1A (DYRK1A) have been described, as a promising therapeutic strategy for diabetes [21]. These 1,5-naphthyridine derivatives 312 (OTS167) exhibit highly potent human $\beta$-cell replication-promoting activity and dramatically reduced cytotoxicity (Figure 32). The generation of several compounds demonstrate an important, underappreciated avenue for lead series development: Desirable, highly potent "off-target" activities of advanced lead compounds.<smiles>CC(=O)c1cnc2ccc(-c3cc(Cl)c(O)c(Cl)c3)nc2c1N[C@H]1CC[C@H](CN(C)C)CC1</smiles>

312 (OTS167)

Figure 32. A human $\beta$-cell replication-promoter.

\subsection{Other Applications}

The physical properties reported for the new 1,5-naphthyiridine derivatives include applications as sensors, semiconductors and solar cells, among others. 


\subsubsection{Light-Emitting Compounds}

It is well known that organic light-emitting diodes (OLEDs), also known as organic EL (electroluminescent) diodes, have acquired a lot of importance since their discovery because they have high efficiency, a long lifetime and a high controllability, compared to conventional lighting devices [139]. In these OLEDs, the emissive electroluminescent layer is a film of organic compound, situated between two electrodes that emits light in response to an electric current. There are three main families of OLED materials, those based on small molecules, polymers and phosphorescent compounds.

Chelated compounds between metals of group III $\left(\mathrm{Al}^{3+}, \mathrm{Ga}^{3+}\right.$ or $\left.\mathrm{In}^{3+}\right)$ and 4-hydroxy-1,5naphthyridines 269 (previously prepared, vide supra, Scheme 108) have been studied as the authentic deep blue analogues of green tris-(8-hydroxyquinoline)aluminium (Figure 33). Therefore, the versatile and effective application of these chelates for OLEDs have been demonstrated [31,140]. These studies determinate the ambipolar charge transport, high carrier mobilities and high dispersive shape of the aluminium chelate derived from 1,5-naphthyridines. Their photophysical properties have been also studied by DFT and TD-DFT theoretical methods [124].

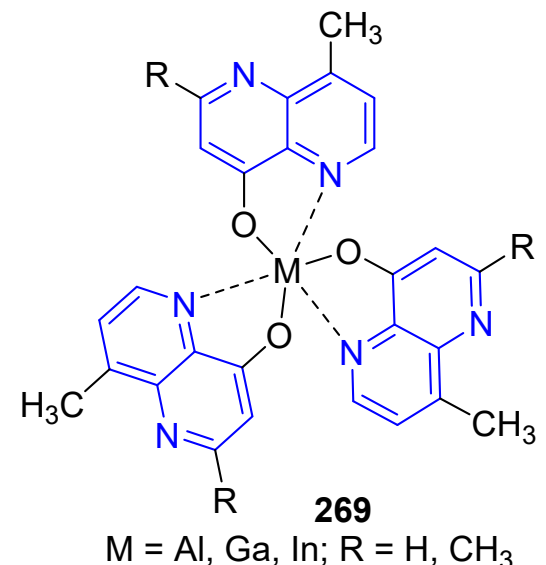

Figure 33. Metal complexes of group III as OLEDs.

Borane naphthyridines containing carboxylic acids, such as derivative $\mathbf{3 1 3}$ (Figure 34), presented electrochemical and electrochemiluminescence properties $[95,141]$. Specifically, this BODIPY carboxylic acid showed a high fluorescence quantum yield, which significantly exceeds the range previously reported for structurally similar dyes. This ability results were very attractive for biological assays since the BODIPY-COOH dyes could easily conjugate to a wide range of biomolecules as it contains a carboxyl terminal. In this sense, as the dye generates significant electrochemiluminescence, these compounds serve an excellent alternative adding fluorescence for dyes with a small Stokes shift.<smiles></smiles>

Figure 34. A BODIPY-linked 1,5-naphthyridine-COOH dye. 
The emission energy of copper complexes are useful for the design of emissive materials. Moreover, changes in $N$-heteroaromatic ligands vary significantly the emission energies over the visible region from red to blue and that emission energies correlated with the reduction potentials of the coordinated $N$-heteroaromatic ligands [114]. In another paper, the peak emission of copper complexes 257 (previously prepared, vide supra, Scheme 103) containing phosphino-1,5-naphthyrine ligands were shifting to the blue region compared to that of quinoline derivative (Figure 35), which could be useful in designing artifices of fluorescent complexes emitting lights that cover a full range of visible colors [115].

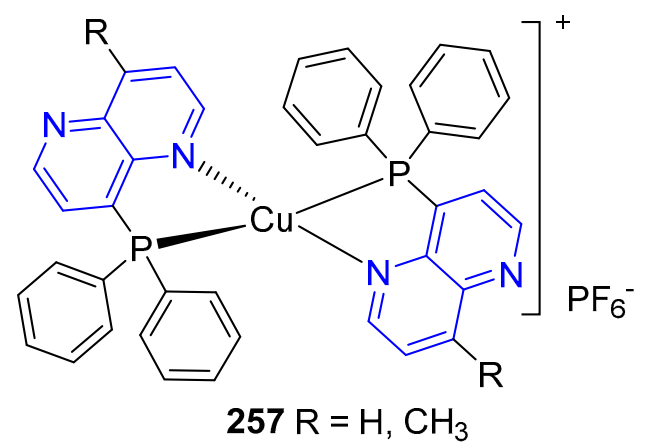

Figure 35. Fluorescent copper complexes.

In the past few decades, white organic light-emitting diodes (WOLEDs) have drawn increasing attention because of their potential applications in full color at-panel displays and solid-state lighting. Therefore, the color of these devices could be tuned from yellow to red by adjusting the doping concentrations. For this reasons, this series of compounds can be used as emitting dyes in light-emitting diodes (LED) [19]. Some heteroleptic platinum (II) complexes with 4-hydroxy-1,5-naphthyridine ligands 254 (previously prepared, vide supra, Scheme 101) were used for the construction of WOLEDs with multilayer structures (Figure 36) [33,113,142].<smiles></smiles>

Figure 36. Platinum complexes as WOLEDs.

In 2016, lanthanide luminescence, based on the Dy ion, under a pulsed magnetic field for single-molecule magnets (SMMs) is observed for the first time in a series of dysprosium compound 262 (previously prepared, vide supra, Scheme 105) coordinated by four naphthyridine like ligands, containing the [DyL4] entity, and linked with an alkali metal ion (Figure 37) [122]. These SMMs will be also attractive multifunctional materials in the application of molecular spintronics and quantum computing.

Similarly, naphthyridine derivatives as ligands have been reported as photoluminescent when forming complexes with europium, such in $\mathbf{2 6 1}$ (previously prepared, vide supra, Scheme 105), with high photoluminescence quantum yields (PLQYs) and high thermo- and photostabilities (Figure 38) [120]. 


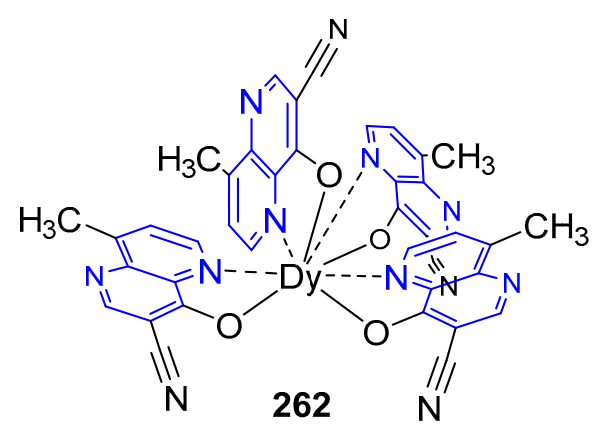

Figure 37. Dysprosium complexes as light emitters.<smiles></smiles>

261

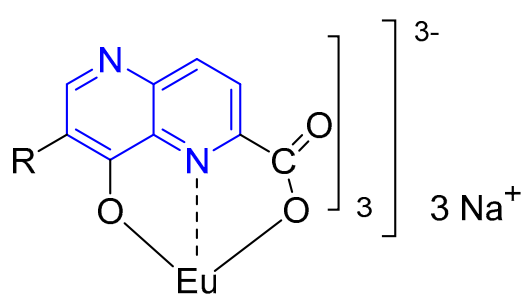

314<smiles></smiles>

315

Figure 38. Europium complexes as light emitters.

The same group, developed carboxyl functionalized naphthyridine ligands in europium(III) complexes 314 [28] or compounds with diphenylphosphoryl group 315 [29]. These compounds result quite promising for potential application in bioimaging and $\mathrm{pH}$ sensing, especially after the coordination stability is further improved by connecting ligands with multidentate groups such as cyclen, coating the complex with oil and nanocapsules, or dispersing the complex in $\mathrm{SiO}_{2}$. Comparing the bidentate complexes with the tridentate complexes, an improved and exceptionally high PLQYs in powder, as well as in a $\mathrm{CH}_{2} \mathrm{Cl}_{2}$ solution and poly(methylmethacrylate) films were observed.

No-metallated compounds, with a simple architecture, are attracting considerable attention in the future display technology as organic light-emitting diodes (OLEDs). In this sense, organic optoelectronic materials based exclusively on a 1,5-naphthyridine core, such as compounds 316, were computationally studied and the quantum chemical calculations suggested that the 4,8-substituted-1,5-naphthyridines might be promising blue-emitting (or blue-green-emitting for 316h) materials, electron transport materials and hole-injecting/hole-transport materials (Figure 39) [20].
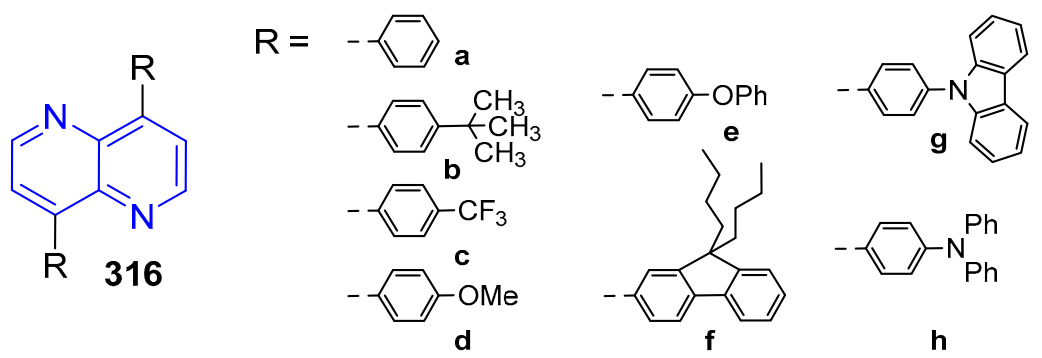

Figure 39. Organic light-emitting diodes.

1,5-Naphthyridinylacridine-based compounds present a great potential as thermally activated delayed fluorescence (TADF) emitters in OLEDs, as indicated in a work of 2019 [66]. In this case, emitting compounds posses a suitable combination of rigid acridine donors and rigid planar naphthyridine or cyan-naphthyridine acceptors in the structures of 317 and 318 (Figure 40). Moreover, the molecule design strategy of incorporating TADF character and agrgregation induced emission (AIE) properties 
into one molecule provides important guidance to develop efficient neat-film emitters for high-efficiency non-doped OLEDs. Or as recently reported, 1,5-naphthyridine with acridine substituent in another position still represents a promising structure for efficient TADF materials [8].<smiles>CC1(C)c2ccccc2N(c2ccnc3cccnc23)c2ccccc21</smiles>

317<smiles>CC1(C)c2ccccc2N(c2c(C#N)cnc3cccnc23)c2ccccc21</smiles>

318

Figure 40. Thermally activated delayed fluorescence (TADF) emitters in OLED.

Based on push-pull-type fluorophores, naphthyridine derivatives are amine sensors based on a chemical reaction between the fluorophore and the amine, and this interaction results in changes in fluorescence. Fluorophore 6 (previously prepared, vide supra, Scheme 2), having two trifluoromethyl groups and a $\mathrm{Cl}$ atom on a 1,5-aminonaphthyridine framework, showed strong solvatochromic fluorescence (Figure 41) [16]. In addition, in the presence of amines such as ethylamine, diethylamine, and aniline, further considerable bathochromic shifts in the fluorescence were observed. Density functional calculations identified the source of the fluorescence behavior as exciplex formation between 15-Nap-Cl and the corresponding amine. The fluorescence behavior was exploited to fabricate a sensor that can identify various primary, secondary, and tertiary amines.<smiles>Nc1cc2nc(C(F)(F)F)cc(C(F)(F)F)c2nc1Cl</smiles>

6

Figure 41. Compound with strong solvatochromic fluorescence.

\subsubsection{Solar Cells}

Organic photovoltaics (OPVs) are particularly promising alternatives for solar-cell generation of energy because of the abundance of their constituent elements and base materials, their low cost, and relative ease of chemical synthesis. Aluminium chelates of 1,5-naphthyridine derivatives have been studied as exciton-blocking material for organic photovoltaics with prolonged lifetime [125,143]. Also $\pi$-conjugated naphthyridine $\mathrm{N} \rightarrow \mathrm{B}$-ladder boranes are materials of interest for use in organic n-type applications in organic electronics [123].

Poly[1,5-naphthyridine-(3-hexylthiophene)] semi-conducting polymer 166 (previously prepared, vide supra, Scheme 70) has been accomplished to be used as polymer-sensitized solar cell (Figure 42) [40]. In this case, solar cells are assembled using functionalized polythiophenes as a photoactive layer offering interesting properties [97]. In 2016, polymers 319 with 1,5-dialkyl-1,5-naphthyridine-2,6-dione 43 (previously prepared, vide supra, Scheme 13) as an electron acceptor and benzo[1,2-b:4,5- $\mathrm{b}^{\prime}$ ]dithiophene (BDT) as an electron donor were designed for producing efficient organic solar cells (Figure 42) [37]. Several insights of these compounds were also studied experimentally and theoretically [144].

Other polymeric compounds, as derivatives 320 exhibited high sensitivity and selectively in detecting iodide ion over a wide range of competing ions, such as $\mathrm{Br}^{-}, \mathrm{Cl}^{-}, \mathrm{F}^{-}, \mathrm{NO}_{3}^{-}, \mathrm{CH}_{3} \mathrm{COO}^{-}$, $\mathrm{SO}_{4}{ }^{2-}, \mathrm{SO}_{3}{ }^{2-}, \mathrm{S}_{2} \mathrm{O}_{3}{ }^{2-}$ and $\mathrm{CN}^{-}$(Figure 43) [67]. The incorporation of long alkoxy and alkyl side chains in the structure of these polymers rendered them better solubility in most common organic solvents, which warrant their suitability for photovoltaic devices application. 
<smiles>CCCCCCc1cc(C(C)(C)C)sc1-c1ccc2nc(C(F)(F)F)ccc2n1</smiles>

166<smiles>[R]Oc1c2cc(sc3c(=O)n([R2])c(=O)c1=3)C1=CC=C(S2)c2cc3c(cc(-c4ccc(C)s4)c(=O)n3[R])c(O[R])c2S1</smiles>

319

Figure 42. Semi-conducting polymers.<smiles>[R]Oc1cc(/C=C/c2ccc(Oc3ccc4nc(Oc5ccc(C)cc5OC)ccc4n3)c(OC)c2)c([R])cc1/C=C/C(C)(C)C</smiles>

Figure 43. Iodide ion detectors.

\subsubsection{Energy Storage}

Focusing on the feasibility of using organic fuels for virtual hydrogen flow cell battery systems, based on thermodynamic considerations of fuel hydrogenation/dehydrogenation reactions, 1,5-naphthyridine derivatives have been studied as assessment of the energy density and open circuit potentials (OCPs) [145]. Heterocyclic saturated hydrocarbons and their dehydrogenation products were promising organic carriers that could yield theoretical OCPs higher than that for the hydrogen fuel cell.

In a screening by ab initio calculations, most of the suitable compounds for use as a film-forming on anodes tended to be isomers of naphthalene containing two nitrogen heteroatoms, such as 1,5-naphthyridine 2a (previously prepared, vide supra, Scheme 1) (Figure 44) [146]. This results of interest in the search of novel functional additives and nonaqueous solvents for use in lithium-ion batteries.<smiles>c1cnc2cccnc2c1</smiles>

$2 a$

\section{$E_{o x}\left(\mathrm{~V} v s . \mathrm{Li} / \mathrm{Li}^{+}\right) \quad E_{r d}\left(\mathrm{~V} v s . \mathrm{Li} / \mathrm{Li}^{+}\right)$ \\ 5.21}

Figure 44. Additives in lithium-ion batteries.

A 1,5-naphthyridine trans-diaquadioxalatochromate (III) dihydrate complex 231 (previously prepared, vide supra, Scheme 94) was classified as semi-conductor (Figure 45) [107]. All the existing spin-allowed transitions presented in the electronic absorption spectrum has been assigned using Tanabe-Sugano diagram and the Racah parameter was calculated to evaluate the nephelauxetic effect of $(\mathrm{Cr} 3 \mathrm{p})$.

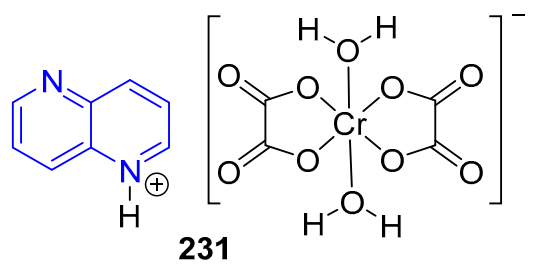

Figure 45. Chromium complex as semi-conductor. 


\section{Conclusions}

In this review, the synthesis and reactivity of 1,5-naphthyridine derivatives published in the last 18 years have been collected. An analysis of the papers indicates that this type of compounds attracts great interest from various points of view, not only in preparative organic synthesis, but also in medicinal and applied chemistry.

In recent years, interest in their possible therapeutic properties against many diseases has increased. In fact, many of the derivatives presented in this review show important biological activity as antiproliferative, antibacterial, antifungal, antiparasitic, antiviral and anti-inflammatory, as well as activity in cardiovascular, hormonal and central nervous system diseases. In addition, a large number of works are related to other applications. Several 1,5-naphthyridines are very interesting compounds as OLEDs or for their use in solar cells.

We expect the data collected in this review, dedicated to the synthesis, reactivity and biological applications of naphthyridine derivatives, will be of interest to organic chemists, medicinal chemists and biologists. On the other hand, the data collected related to the electrical and optical properties of 1,5-naphthyridine derivatives will be useful for the development of new technologies.

Author Contributions: Conceptualization, G.R., F.P., C.A.; writing-original draft preparation, M.F., C.M.; writing-review and editing, M.F., C.M., E.M.-E., A.S., G.R., F.P., C.A.; supervision, F.P., C.A.; project administration, F.P., C.A.; funding acquisition, F.P., C.A. All authors have read and agreed to the published version of the manuscript.

Funding: This research was funded by the Ministerio de Ciencia, Innovación y Universidades (MCIU), Agencia Estatal de Investigación (AEI), Fondo Europeo de Desarrollo Regional (FEDER; RTI2018-101818-B-I00, UE) and by Gobierno Vasco, Universidad del País Vasco (GV, IT 992-16; UPV).

Conflicts of Interest: The authors declare no conflict of interest.

\section{References}

1. Allen, C.F.H. The naphthyridines. Chem. Rev. 1950, 47, 2, 275-305. [CrossRef] [PubMed]

2. Litvinov, V.P.; Roman, S.V.; Dyachenko, V.D. Naphthyridines. Structure, physicochemical properties and general methods of synthesis. Russ. Chem. Rev. 2000, 69, 201-220. [CrossRef]

3. Litvinov, V.P.; Roman, S.V.; Dyachenko, V.D. Pyridopyridines. Russ. Chem. Rev. 2001, 70, 299-320. [CrossRef]

4. Litvinov, V.P. Advances in the chemistry of naphthyridines. Adv. Heterocycl. Chem. 2006, 91, 189-300.

5. Reissert, A. Weber di-(y-amidopropyl)esaigeiiure(diamino-1,7-heptanmethylsaure-4) und ihr inneres condeneations product, dee octohydro-1,8-naphthyridine. Berichte 1893, 26, 2137-2144.

6. Bobranski, B.; Sucharda, E. A synthesis of 1,5-naphthyridine. Berichte 1927, 60, 1081.

7. Chunavala, K.C.; Adimurthy, S. Iodine- and Indium (III) chloride-catalized facile syntheses of 1,5- and 1,8-naphthyridines. Synth. Commun. 2011, 41, 1843-1851. [CrossRef]

8. Lee, Y.; Woo, S.-J.; Kim, J.-J.; Hong, J.-I. Linear-shaped thermally activated delayed fluorescence emitter using 1,5-naphthyridine as an electron acceptor for efficient light extraction. Org. Electron. 2020, 78, 105600. [CrossRef]

9. Wu, J.-F.; Liu, M.-M.; Huang, S.-X.; Wang, Y. Design and synthesis of novel substituted naphthyridines as potential c-Met kinase inhibitors based on MK-2461. Bioorg. Med. Chem. Lett. 2015, 25, 3251-3255. [CrossRef]

10. Defaux, J.; Maud, A.; Loge, C.; Le Borgne, M.; Schuster, T.; Seipelt, I.; Aicher, B.; Teifel, M.; Gunther, E.; Gerlach, M.; et al. Discovery of (7-aryl-1,5-naphthyridin-2-yl)ureas as dual inhibitors of ERK2 and aurora B kinases with antiproliferative activity against cancer cells. Bioorg. Med. Chem. Lett. 2014, 24, 3748-3752. [CrossRef]

11. Zhu, S.; Zhang, Q.; Gudise, C.; Meng, L.; Wei, L.; Smith, E.; Kong, Y. Synthesis and evaluation of naphthyridine compounds as antimalarial agents. Bioorg. Med. Chem. Lett. 2007, 17, 6101-6106. [CrossRef]

12. Magee, T.V.; Ripp, S.L.; Li, B.; Buzon, R.A.; Chupak, L.; Dougherty, T.J.; Finegan, S.M.; Girard, D.; Hagen, A.E.; Falcone, M.J.; et al. Discovery of azetidinyl ketolides for the treatment of susceptible and multidrug resistant community-acquired respiratory tract infections. J. Med. Chem. 2009, 52, 7446-7457. [CrossRef] [PubMed]

13. Li, B.; Magee, T.V.; Buzon, R.A.; Widlicka, D.W.; Bill, D.R.; Brandt, T.; Cao, X.; Coutant, M.; Dou, H.; Granskog, K.; et al. Process development of a novel azetidinyl ketolide antibiotic. Org. Process Res. Dev. 2012, 16, 788-797. [CrossRef] 
14. Li, B.; Widlicka, D.W.; Buzon, R.A.; Dou, H.; Grasnskog, K.; Flanagan, M.E.; Li, B.; Liu, F.; Liu, W.; Magee, T.V.; et al. A scalable synthesis of 3-hydroxy-1,5-naphthyridine-4-carbaldehyde. Synlett 2010, 2, 250-252. [CrossRef]

15. Gellibert, F.; Woolven, J.; Fouchet, M.H.; Mathews, N.; Goodland, H.; Lovegrove, V.; Laroze, A.; Nguyen, V.L.; Sautet, S.; Wang, R.; et al. Identification of 1,5-naphthyridine derivatives as a novel serie of potent and selective TGF- $\beta$ type I receptor inhibitors. J. Med. Chem. 2004, 47, 4494-4506. [CrossRef]

16. Hirota, J.; Usui, K.; Fuchi, Y.; Sakuma, M.; Matsumoto, S.; Hagihara, R.; Karasawa, S. Fluorescence properties and exciplex formation of emissive naphthyridine derivatives: Application as sensors for amines. Chem. Eur. J. 2019, 25, 14943-14952. [CrossRef] [PubMed]

17. Brown, S.B.; Dewar, M.J.S. Centrosymmetric 1,5-naphthyridine derivatives: Synthesis, tautomerism, and termal rearrangements. J. Org. Chem. 1978, 43, 1331-1337. [CrossRef]

18. Papadopoulou, M.V.; Bloomer, W.D. Nitroimidazole-based bioreductive compounds bearing a quinazoline or a napthyridine chromophore. Anti-Cancer Drugs 2009, 20, 493-502. [CrossRef]

19. Chien, C.T.; Shiu, J.R.; Chang, C.P.; Hon, Y.S.; Huang, D.F.; Chou, P.T.; Liu, C.Y.; Chow, T.J. Platinium complexes of 4-hydroxy-1,5-naphthyridines as emitting dyes. J. Chin. Chem. Soc. 2012, 59, 357-364. [CrossRef]

20. Wang, K.Y.; Chen, C.; Liu, J.F.; Wang, Q.; Chang, J.; Zhu, H.J.; Li, C. Novel multifunctional organic semiconductor materials base don 4,8-substituted 1,5-naphthyridine: Synthesis, single cristal structures, opto-electrical properties and quantum chemistry calculation. Org. Biomol. Chem. 2012, 10, 6693-6704. [CrossRef]

21. Allegretti, P.A.; Horton, T.M.; Abdolazimi, Y.; Moeller, H.P.; Yeh, B.; Caffet, M.; Guillermina, M.; Smith, M.; Annes, J.P. Generation of highly potent DYRK1A-dependent inducers of human $\beta$-cell replication via multi-dimensional compound optimization. Biorg. Med. Chem. 2020, 28, 115193. [CrossRef]

22. Zeng, J.; Lü, X.; Zeng, C.; Hu, L.; Zhong, R. Design, synthesis and anti-hiv integrase evaluation of 1,2,3-triazol-4-yl-substituted 1,4-dihydro-4-oxo-1,5-naphthyridine-3-carboxilic acids. Chin. J. Chem. 2009, 27, 953-962. [CrossRef]

23. Beaudin, J.; Bourassa, D.E.; Bowles, P.; Castaldi, M.J.; Clay, R.; Couturier, M.A.; Karrick, G.; Makowski, T.W.; McDermott, R.E.; Meltz, C.N.; et al. Synthesis and purification of 3-ethoxy-4-oxo1,4-dihydro-1,5-naphthyridine-3-carboxylic acid benzylamid. Org. Process. Res. Develop. 2003, 7, 873-878. [CrossRef]

24. Mirguet, O.; Lamotte, Y.; Chung, C.-W.; Bamborough, P.; Delannée, D.; Bouillot, A.; Gellibert, F.; Krysa, G.; Lewis, A.; Witherington, J.; et al. Naphthyridines as novel BET family bromodomain inhibitors. Chem. Med. Chem. 2014, 9, 580-589. [CrossRef]

25. Singh, S.B.; Kaelin, D.E.; Wu, J.; Miesel, L.; Tan, C.M.; Meinke, P.T.; Olsen, D.; Lagrutta, A.; Bradley, P.; Lu, J.S.; et al. Oxabicyclooctane-linked novel bacterial topoisomerase inhibitors as broad spectrum antibacterial agents. ACS Med. Chem. Lett. 2014, 5, 609-614. [CrossRef]

26. Abele, S.; Schmidt, G.; Fleming, M.J.; Steiner, H. A one-pot diazotation fluorodediazoniation reaction and fluorine gas for the production of fluoronaphthyridines. Org. Process Res. Dev. 2014, 18, 993-1001. [CrossRef]

27. Selakovic, Z.; Tran, J.P.; Kota, K.P.; Lazic, M.; Retterer, C.; Besh, R.; Panchal, R.G.; Soloveva, V.; Vantongreen, A.S.; Welles, B.J.; et al. Second generation of diazachrysenes: Protection of ebola virus infected mice and mechanism of action. Eur. J. Med. Chem. 2019, 162, 32-50. [CrossRef] [PubMed]

28. Wei, C.; Wei, H.; Yan, W.; Zhao, Z.; Cai, Z.; Sun, B.; Meng, Z.; Liu, Z.; Bian, Z.; Huang, C. Water-soluble and highly luminescent europium (III) complexes with favorable photostability and sensitive $\mathrm{pH}$ response behavior. Inorg. Chem. 2016, 55, 10645-10653. [CrossRef] [PubMed]

29. Wei, C.; Sun, B.; Cai, Z.; Zhao, Z.; Tan, Y.; Yan, W.; Wei, H.; Liu, Z.; Bian, Z.; Huang, C. Quantum yields over $80 \%$ achieved in luminescent europium complexes by employing diphenylphosphoryl tridentate ligands. Inorg. Chem. 2018, 57, 7512-7515. [CrossRef]

30. Wang, Z. Comprehensive Organic Name Reactions and Reagents; John Wiley \& Sons: Hoboken, NJ, USA, $2009 ;$ p. 3824.

31. Liao, S.H.; Shiu, J.R.; Liu, S.W.; Yeh, S.J.; Chen, Y.H.; Chen, C.T.; Chow, T.J.; Wu, C.I. Hydroxynaphthyridine-derived group III metal chelates: Wide band gap and deeep blue analogues of green Alq3(tris(8-hydroxyquinolate)aluminium) and their versatile applications for organic light-emitting diodes. J. Am. Chem. Soc. 2009, 131, 763-777. [CrossRef] 
32. Defaux, J.; Antoine, M.; Le Borgne, M.; Schuster, T.; Seipelt, I.; Aicher, B.; Teifel, M.; Guenther, E.; Gerlach, M.; Marchand, P. Discovery of 7-aryl-substituted (1,5-naphthyridin-4-yl)ureas as aurora kinase inhibitors. ChemMedChem 2014, 9, 217-232. [CrossRef] [PubMed]

33. Poloek, A.; Lin, C.W.; Chen, C.T. High color rendering index and color stable hybrid white efficient OLEDs with a double emitting layer structure using a single phosphorescence dopant of heteroleptic platinum complexes. J. Mater. Chem. C 2014, 2, 10343-10356. [CrossRef]

34. Perez, C.; Li, J.; Parlati, F.; Rouffet, M.; Ma, Y.; Mackinnon, A.L.; Chou, T.-F.; Deshaies, R.J.; Cohen, S.M. Discovery of an inhibitor of the proteasome subunit rpn11. J. Med. Chem. 2017, 60, 1343-1361. [CrossRef] [PubMed]

35. Kandepedu, N.; González-Cabrera, D.; Eedubilli, S.; Taylor, D.; Brunschwig, C.; Gibhard, L.; Njoroge, M.; Lawrence, N.; Paquet, T.; Eyermann, C.J.; et al. Identification, characterization, and optimization of 2,8disubstituted-1,5-naphthyridines as novel plasmodium falciparum phosphatidylinositol-4-kinase inhibitors with in vivo efficacy in a humanized mouse model of malaria. J. Med. Chem. 2018, 61, 5692-5703. [CrossRef]

36. Hameed, S.; Raichurkar, A.; Madhavapeddi, P.; Menasinakai, S.; Sharma, S.; Kaur, P.; Nandishaiah, R.; Panduga, V.; Reddy, J.; Sambandamurthy, V.K.; et al. Benzimidazoles: Novel mycobacterial gyrase inhibitors from scaffold morphing. ACS Med. Chem. Lett. 2014, 5, 820-825. [CrossRef]

37. Yoon, W.S.; Kim, D.W.; Park, J.-M.; Cho, I.; Kwon, O.K.; Whang, D.R.; Kim, J.H.; Park, J.-H.; Park, S.Y. A novel bis-lactam acceptor with outstanding molar extinction coefficient and structural planarity for donor-acceptor type conjugated polymer. Macromolecules 2016, 49, 8489-8497. [CrossRef]

38. Rombouts, F.J.R.; Andres, J.-I.; Ariza, M.; Alonso, J.M.; Austin, N.; Bottelbergs, A.; Chen, L.; Chupakhin, V.; Cleiren, E.; Fierens, K.; et al. Discovery of $N$-(pyridin-4-yl)-1,5-naphthyridin-2-amines as potential tau pathology PET tracers for Alzheimer's disease. J. Med. Chem. 2017, 60, 1272-1291. [CrossRef]

39. Shen, Z.-L.; Dhayalan, V.; Benischke, A.D.; Greiner, R.; Karaghiosoff, K.; Mayer, P.; Knochel, P. Polyfunctional lithium, magnesium, and zinc alkenyl reagents as building blocks for the synthesis of complex heterocycles. Angew. Chem. Int. Ed. 2016, 55, 5332-5336. [CrossRef]

40. Siddiqui, M.; Ullah, N.; Al-Betar, A.; Al-Saadi, A. Synthesis of functionalized polythiophene as a potenial organic semi-conductor. MATEC Web Conf. 2016, 49, 02001/1-02001/7. [CrossRef]

41. Alonso, C.; González, M.; Palacios, F.; Rubiales, G. Study of the hetero-[4+2]-cycloaddition reaction of aldimines and alkynes. Synthesis of 1,5-naphthyridine and isoindolone derivatives. J. Org. Chem. 2017, 82, 6379-6387. [CrossRef]

42. Ghashghaei, O.; Masdeu, C.; Alonso, C.; Palacios, F.; Lavilla, R. Recent advances of the Povarov reaction in medicinal chemistry. Drug Discov. Today 2018, 29, 71-79. [CrossRef] [PubMed]

43. Palacios, F.; Alonso, C.; Arrieta, A.; Cossio, F.P.; Ezpeleta, J.M.; Fuertes, M.; Rubiales, G. Lewis acid activated aza-Diels-Alder reaction of $\mathrm{n}$-(3pyridyl)aldimines: An experimental and computational study. Eur. J. Org. Chem. 2010, 2010, 2091-2099. [CrossRef]

44. Palacios, F.; Alonso, C.; Fuertes, M.; Ezpeleta, J.M.; Rubiales, G. Glyoxalate-derived aldimines in cycloaddition reactions with olefins. Eur. J. Org. Chem. 2011, 23, 4318-4326. [CrossRef]

45. Alonso, C.; Fuertes, M.; González, M.; Rodríguez-Gascón, A.; Rubiales, G.; Palacios, F. Synthesis and biological evaluation of 1,5-naphthyridines as topoisomerase I inhibitors. A new family of antiproliferative agents. Curr. Top. Med. Chem. 2014, 14, 2722-2728. [CrossRef] [PubMed]

46. Tejeria, A.; Pérez-Pertejo, Y.; Reguera, R.M.; Balana-Fouce, R.; Alonso, C.; González, M.; Rubiales, G.; Palacios, F. Substituted 1,5-naphthyridine derivatives as novel antileishmanial agents. Synthesis and biological evaluation. Eur. J. Med. Chem. 2018, 152, 137-147. [CrossRef]

47. Fernandez, M.C.; Escribano, A.; Mateo, A.I.; Parthasarathy, S.; Martin de la Nava, E.M.; Wang, X.; Cockerham, S.L.; Beyer, T.P.; Schmidt, R.J.; Cao, G.; et al. Desing, synthesis and structure-activity-relationship of 1,5-tetrahydronaphthyridines as CEPT inhibitors. Bioorg. Med. Chem. Lett. 2012, 22, 3056-3062. [CrossRef]

48. Woo, G.H.C.; Beeler, A.B.; Snyder, J.K. 1,2,3,4-Tetrahydro-1,5-naphthyridines and related heterocyclic scaffolds: Exploration of suitable chemistry for library development. Tetrahedron 2007, 63, 5649-5655. [CrossRef]

49. Yoon, W.S.; Won Kim, D.; Choi, M.-W.; Park, J.-M.; Park, S.Y. Designing 1,5-naphthyridine-2,6-dione-based conjugated polymers for higher crystallinity and enhanced light absorption to achieve $9.63 \%$ efficiency polymer solar cells. Adv. Energy Mater. 2018, 8, 1701467. [CrossRef] 
50. Alonso, C.; Martinez de Marigorta, E.; Rubiales, G.; Palacios, F. Trifluoromethylation reactions of hydrocarbon derivatives and heteroarenes. Chem. Rev. 2015, 115, 1847-1935. [CrossRef]

51. Shirai, T.; Kanai, M.; Kuninobu, Y. 2-Position-selective C-H perfluoroalkylation of quinoline derivatives. Org. Lett. 2018, 20, 1593-1596. [CrossRef]

52. Nagase, M.; Kuninobu, Y.; Kanai, M. 4-Position-selective C-H perfluoroalkylation and perfluoroarylation of six-membered heteroaromatic compounds. J. Am. Chem. Soc. 2016, 138, 6103-6106. [CrossRef] [PubMed]

53. Singh, S.B.; Kaelin, D.E.; Wu, J.; Miesel, L.; Tan, C.M.; Meinke, P.T.; Olsen, D.B.; Lagrutta, A.; Wei, C.; Peng, X.; et al. Structure activity relationship of substituted 1,5-naphthyridine analogs of oxabicyclooctane-linked novel bacterial topoisomerase inhibitors as broad-spectrum antibacterial agents (Part 4). Bioorg. Med. Chem. Lett. 2015, 25, 2409-2415. [CrossRef] [PubMed]

54. Bouarfa, S.; Grassl, S.; Ivanova, M.; Langlais, T.; Bentabed-Ababsa, G.M.; Lassagne, F.; Erb, W.; Roisnel, T.; Dorcet, V.; Knochel, P.; et al. Copper- and cobalt-catalyzed syntheses of thiophene-based tertiary amines. Eur. J. Org. Chem. 2019, 20, 3244-3258. [CrossRef]

55. Grzegozek, M.; Szpakiewicz, B. Methylamination of some 3-nitro-1,5-naphthyridines with liquid methylamine/potassium permanganate. J. Heterocyclic Chem. 2006, 43, 425-430. [CrossRef]

56. Palacios, F.; Alonso, C.; De los Santos, J.M. Synthesis of $\beta$-aminophosphonates and -phosphinates. Chem. Rev. 2005, 105, 899-931. [CrossRef]

57. Radai, Z.; Keglevich, G. Synthesis and reactions of $\alpha$-hydroxyphosphonates. Molecules 2018, $23,1493$. [CrossRef]

58. Van Waes, F.E.A.; Debrouwer, W.; Heugebaert, T.S.A.; Stevens, C.V. On the discovery and development of tandem 1,4- and 1,2-addition of phosphites to 1-azadienes. Arkivoc 2014, 386-427. [CrossRef]

59. De Blieck, A.; Catak, S.; Debrouwer, W.; Drabowicz, J.; Hemelsoet, K.; Verstraelen, T.; Waroquier, M.; Van Speybroeck, V.; Stevens, C.V. Diphosphonylation of aromatic diazaheterocycles and theoretical rationalization of product yields. Eur. J. Org. Chem. 2013, 1058-1067. [CrossRef]

60. Levy, J.N.; Alegre-Requena, J.V.; Liu, R.; Paton, R.S.; McNally, A. Selective halogenation of pyridines using designed phosphine reagents. J. Am. Chem. Soc. 2020, 142, 11295-11305. [CrossRef]

61. Adams, J.T.; Bradsher, C.K.; Breslow, D.S.; Amore, S.T.; Hauser, C.R. Synthesis of antimalarials. Synthesis of certain 1,5- and 1,8-naphthyridine derivatives. J. Am. Chem. Soc. 1946, 68, 1317-1319. [CrossRef]

62. Sieb, D.; Schuhen, K.; Morgen, M.; Herrmann, H.; Wadepohl, H.; Lucas, N.T.; Baker, R.W.; Enders, M. Synthesis and complexation behavior of indenyl and cyclopentadienyl ligands functionalized with a naphthyridine unit. Organomettalics 2012, 31, 356-364. [CrossRef]

63. Fitchett, C.M.; Steel, P.J. Synthesis and X-ray structures of two discrete metal complexes of 2,2'-bi-1,5-naphthyridine, a new ambivergent ligand. Polyhedron 2007, 26, 400-405. [CrossRef]

64. McElhinny, C.J., Jr.; Lewin, A.H.; Mascarella, S.W.; Runyon, S.; Brieaddy, L.; Carroll, F.I. Hydrolytic instability of the important orexin 1 receptor antagonist SB-334867: Possible confounding effects on in vivo and in vitro studies. Bioorg. Med. Chem. Lett. 2012, 22, 6661-6664. [CrossRef] [PubMed]

65. Surivet, J.-P.; Zumbrum, C.; Rueedi, G.; Hubschwerlen, C.; Bur, D.; Bruyére, T.; Locher, H.; Ritz, D.; Keck, W.; Seiler, P.; et al. Design, synhesis and characterization of novel tretrahydropyran-based bacterial topoisomerase inhibitors with potent anti-gram-positive activity. J. Med. Chem. 2013, 56, 7396-7415. [CrossRef] [PubMed]

66. Zhou, X.; Yang, H.; Chen, Z.; Gong, S.; Lu, Z.-H.; Yang, C. Naphthyridine-based emitters simultaneously exhibiting thermally activated delayed fluorescence and aggregation-induced emission for highly efficient non-doped fluorescent OLEDs. J. Mat. Chem. C Mater. Opt. Electron. Devices 2019, 7, 6607-6615. [CrossRef]

67. Boali, A.A.; Mansha, M.; Waheed, A.; Ullah, N. Synthesis and selective colorimetric detection of iodide ion by novel 1,5-naphthyridine-based conjugated polymers. J. Taiwan Inst. Chem. E. 2018, 91, 420-426. [CrossRef]

68. Mansha, M.; Younas, M.; Gondal, M.A.; Ullah, N. 1,5-Naphthyridine-based conjugated polymers as co-sensitizers for dye-sensitized solar cells. Sol. Energy 2019, 194, 682-687. [CrossRef]

69. Lahue, B.R.; Lo, S.-M.; Wan, Z.-K.; Woo, G.H.C.; Snyder, J.K. Intramolecular inverse-electron-demand Diels-Alder reactions of imidazoles with 1,2,4-triazines: A new route to 1,2,3,4-tetrahydro-1,5-naphthyridines and related heterocycles. J. Org. Chem. 2004, 69, 7171-71822. [CrossRef]

70. He, K.-H.; Tan, F.-F.; Zhou, C.-Z.; Zhou, G.-J.; Yang, X.-L.; Li, Y. Acceptorless dehydrogenation of $\mathrm{N}$-heterocycles by merging visible-light photoredox catalysis and cobalt catalysis. Angew. Chem. Intern. Ed. 2017, 56, 3080-3084. [CrossRef] 
71. Fujita, K.-I.; Tanaka, Y.; Kobayashi, M.; Yamaguchi, R. Homogeneous perdehydrogenation and perhydrogenation of fused bicyclic $N$-heterocycles catalyzed by Iridium complexes bearing a functional bipyridonate ligand. J. Am. Chem. Soc. 2014, 136, 4829-4832. [CrossRef]

72. Petkevicius, V.; Vaitekunas, J.; Tauraite, D.; Stankeviciute, J.; Sarlauskas, J.; Cenas, N.; Meskys, R. A biocatalytic synthesis of heteroaromatic N-oxides by whole cells of Escherichia coli expressing the multicomponent, soluble di-iron monooxygenase (SDIMO) PmlABCDEF. Adv. Synth. Catal. 2019, 361, 2456-2465. [CrossRef]

73. Nishimura, N.; Siegmund, A.; Liu, L.; Yang, K.; Bryan, M.C.; Andrews, K.L.; Bo, Y.; Booker, S.K.; Caenepeel, S.; Freeman, D.; et al. Phospshoinositide 3-kinase (PI3K)/mamalian target of rapamycin (mTOR) dual inhibitors: Discovery and structure-activity relationship of a series of quinoline and quinoxaline derivatives. J. Med. Chem. 2011, 54, 4735-4751. [CrossRef] [PubMed]

74. Singh, A.N.; Thummel, R. 1,5-Naphthyridine as a new linker for the construction of bidging ligands and their corresponding Ru(II) complexes. Inorg. Chem 2009, 48, 6459-6470. [CrossRef] [PubMed]

75. Sarmah, B.K.; Konwar, M.; Bhattacharyya, D.; Adhikari, P.; Das, A. Regioselective cyanation of six-membered $N$-heteroaromatic compounds under metal-, activator-, base- and solvent-free conditions. Adv. Synth. Catal. 2019, 361, 5616-5625. [CrossRef]

76. Liu, C.; Rong, Z.; Sun, Z.; Wang, Y.; Du, W.; Wang, Y.; Lu, L. Quenched skeletal Ni as the effective catalyst for selective partial hydrogenation of polycyclic aromatic hydrocarbons. RSC Adv. 2013, 23984-23988. [CrossRef]

77. Chen, F.; Surkus, A.-E.; He, L.; Pohl, M.-M.; Radnik, J.; Topf, C.; Junge, K.; Beller, M. Selective catalytic hydrogenation of heteroarenes with $N$-graphene-modified cobalt nanoparticles (Co3O4-Co/NGr@a-Al2O3). J. Am. Chem. Soc. 2015, 137, 11718-11724. [CrossRef] [PubMed]

78. Xu, R.; Chakraborty, S.; Yuan, H.; Jones, W.D. Acceptorless, reversible dehydrogenation and hydrogenation of N-heterocycles with a cobalt pincer catalyst. ACS Catal. 2015, 5, 6350-6354. [CrossRef]

79. Cabrero-Antonino, J.R.; Adam, R.; Junge, K.; Jackstell, R.; Beller, M. Cobalt-catalysed transfer hydrogenation of quinolines and related heterocycles using formic acid under mild conditions. Catal. Sci. Technol. 2017, 7, 1981-1985. [CrossRef]

80. Mai, V.H.; Nikonov, G.I. Transfer hydrogenation of nitriles, olefins, and $N$-heterocycles catalyzed by an N-heterocyclic carbene-supported half-sandwich complex of ruthenium. Organometallics 2016, 35, 943-949. [CrossRef]

81. Alshakova, I.D.; Gabidullin, B.; Nikonov, G.I. Ru-catalyzed transfer hydrogenation of nitriles, aromatics, olefins, alkynes and esters. ChemCatChem 2018, 10, 4874-4883. [CrossRef]

82. Xuan, Q.; Song, Q. Diboron-assisted palladium-catalyzed transfer hydrogenation of $N$-heteroaromatics with water as hydrogen donor and solvent. Org. Lett. 2016, 18, 4250-4253. [CrossRef]

83. Fu, Y.; Sun, J. HMPA-catalyzed transfer hydrogenation of 3-carbonyl pyridines and other $N$-heteroarenes with trichlorosilane. Molecules 2019, 24, 401. [CrossRef] [PubMed]

84. Dubey, A.; Rahaman, S.M.W.; Fayzullin, R.R.; Khusnutdinova, J.R. Transfer hydrogenation of carbonyl groups, imines and N-heterocycles catalyzed by simple, bipyridine-based MnI complexes. ChemCatChem 2019, 11, 3844-3852. [CrossRef]

85. Papa, V.; Yixuan, C.; Spannenberg, A.; Junge, K.; Beller, M. Development of a practical non-noble metal catalyst for hydrogenation of N-heteroarenes. Nat. Catal. 2020, 3, 135-142. [CrossRef]

86. Mai, V.H.; Gadzhiev, O.B.; Ignatov, S.K.; Nikonov, G.I. H/D exchange in N-heterocycles catalysed by an NHC-supported ruthenium complex. Catal. Sci. Technol. 2019, 9, 3398-3407. [CrossRef]

87. Chen, F.; Sahoo, B.; Kreyenschulte, C.; Lund, H.; Zeng, M.; He, L.; Junge, K.; Beller, M. Selective cobalt nanoparticles for catalytic transfer hydrogenation of $N$-heteroarenes. Chem. Sci. 2017, 8, 6239-6246. [CrossRef] [PubMed]

88. Fischer, T.; Bamberger, J.; Mancheno, O. Asymmetric nucleophilic dearomatization of diazarenes by anion-binding catalysis. Org. Biomol. Chem. 2016, 14, 5794-5802. [CrossRef]

89. Zhang, J.; Chen, F.; He, Y.-M.; Fan, Q.-H. Asymmetric ruthenium-catalyzed hydrogenation of 2,6-disubstituted 1,5-naphthyridines: Access to chiral 1,5-diaza-cis-decalins. Angew. Chem. Int. Ed. 2015, 54, 4622-4625. [CrossRef]

90. Balkenhohl, M.; Greiner, R.; Makarov, I.S.; Heinz, B.; Karaghiosoff, K.; Zipse, H.; Knochel, P. Zn-, $\mathrm{Mg}-$, and Li-TMP bases for the successive regioselective metalations of the 1,5-naphthyridine scaffold (TMP=2,2,6,6-Tetramethylpiperidyl). Chem.-Eur. J. 2017, 23, 13046-13050. [CrossRef] 
91. Singh, S.B.; Kaelin, D.E.; Wu, J.; Miesel, L.; Tan, C.M.; Meinke, P.T.; Olsen, D.B.; Lagrutta, A.; Wei, C.; Liao, Y.; et al. C1-C2-linker substituted 1,5-naphthyridine analogues of oxabicyclooctane-linked NBTIs as broad-spectrum antibacterial agents (part 7). MedChem Comm 2015, 6, 1773-1780. [CrossRef]

92. Norman, P. Novel 1,5-naphthyridine PI3K $\delta$ inhibitors, an evaluation of WO2011075628. Expert Opin. Ther. Patents 2011, 21, 1805-1810. [CrossRef]

93. Mohammed, S.; Maher, K.A. Synthesis and spectral characterization of 1,5-naphthyridine derivatives through cross-coupling Suzuki reaction. Indian J. Heterocy. Chem. 2019, 29, 199-203.

94. Galatsis, P.; Yamagata, K.; Wendt, J.A.; Connolly, C.J.; Mickelson, J.W.; Milbank, J.B.J.; Bove, S.E.; Knauer, C.S.; Brooker, R.M.; Augelli-Szafran, C.E.; et al. Synthesis and SAR comparasion of regioisomeric aryl naphthyridines as potent mGlu5 receptor antagonists. Bioorg. Med. Chem. 2007, 17, 6525-6528. [CrossRef] [PubMed]

95. Martin, A.; Long, C.; Forster, R.J.; Keyes, T.E. Near IR emitting BODIPY fluorophores with mega-stokes shifts. Chem. Commun. 2012, 48, 5617-5619. [CrossRef] [PubMed]

96. Li, L.; Okumu, A.A.; Nolan, S.; English, A.; Vibhute, S.; Lu, Y.; Hervert-Thomas, K.; Seffernick, J.T.; Azap, L.; Cole, S.L.; et al. 1,3-Dioxane-linked bacterial topoisomerase inhibitors with enhanced antibacterial activity and reduced hERG inhibition. ACS Infec. Dis. 2019, 5, 1115-1128. [CrossRef] [PubMed]

97. Siddiqui, M.N.; Mansha, M.; Mehmood, U.; Ullah, N.; Al-Betar, A.F.; Al-Saadi, A.A. Synthesis and characterization of functionalized polythiophene for polymer-sensitized solar cell. Dye. Pigment. 2017, 141, 406-412. [CrossRef]

98. Parhi, A.K.; Zhang, Y.; Saionz, K.W.; Pradhan, P.; Kaul, M.; Trivedi, K.; Pilch, D.S.; LaVoie, E.J. Antibacterial activity of quinoxalines, quinazolines, and 1,5-naphthyridines. Bioorg. Med. Chem. Lett. 2013, 23, 4968-4974. [CrossRef]

99. Capani, J.S.; Cochran, J.E.; Liang, J. CsF-mediated in situ desilylation of TMS-alkynes for Sonogashira reaction. J. Org. Chem. 2019, 84, 9378-9384. [CrossRef]

100. Bosset, C.; Beucher, H.; Bretel, G.; Pasquier, E.; Queguiner, L.; Henry, C.; Vos, A.; Edwards, J.P.; Meerpoel, L.; Berthelot, D. Minisci-photoredox-mediated a-heteroarylation of $N$-protected secondary amines: Remarkable selectivity of azetidines. Org. Lett. 2018, 20, 6003-6006. [CrossRef]

101. Osman, K.T.; Ye, J.; Shi, Z.; Toker, C.; Lovato, D.; Jumani, R.S.; Zuercher, W.; Huston, C.D.; Edwards, A.M.; Lautens, M.; et al. Discovery and structure activity relationship of the first potent cryptosporidium FIKK kinase inhibitor. Bioorg. Med. Chem. 2017, 25, 1672-1680. [CrossRef]

102. Bregman, H.; Chakka, N.; Guzman-Perez, A.; Gunaydin, H.; Gu, X.; Huang, X.; Berry, V.; Liu, J.; Teffera, Y.; Huang, L.; et al. Discovery of novel, induced-pocket binding oxazolidinones as potent, selective, and orally bioavailable tankyrase inhibitors. J. Med. Chem. 2013, 56, 4320-4342. [CrossRef]

103. Golec, B.; Kijak, M.; Vetokhina, V.; Gorski, A.; Thummel, R.P.; Herbich, J.; Waluk, J. Solvent-induced changes in photophysics and photostability of indole-naphthyridines. J. Phys. Chem. B 2015, 119, 7283-7293. [CrossRef] [PubMed]

104. Singh, S.B.; Kaelin, D.E.; Meinke, P.T.; Wu, J.; Miesel, L.; Tan, C.M.; Olsen, D.B.; Lagrutta, A.; Fukuda, H.; Kishii, R.; et al. Structure activity relationship of C-2 ether substituted 1,5-naphthyridine analogs of oxabicyclooctanelinked novel bacterial topoisomerase inhibitors as broad-spectrum antibacterial agents (Part-5). Bioorg. Med. Chem. Lett. 2015, 25, 3630-3635. [CrossRef] [PubMed]

105. Perrey, D.A.; Gilmour, B.P.; Runyon, S.P.; Thomas, B.F.; Zhang, Y. Diaryl urea anologues of SB-334867 as orexin-1 receptor antagonists. Bioorg. Med. Chem. Lett. 2011, 21, 2980-2985. [CrossRef] [PubMed]

106. Golec, B.; Nawara, K.; Thummel, R.P.; Waluk, J. Photoinduced oxidation of an indole derivative: 2-(1'H-indol-2'-yl)-1,5-naphthyridine. Photoch. Photobio Sci. 2019, 18, 2225-2231. [CrossRef] [PubMed]

107. Dridi, R.; Dhieb, C.; Cherni, S.N.; Boudjada, N.C.; Zouaoui, N.S.; Faouzi Zid, M. A new supramolecular chromium(III) complex: Synthesis, structural determination, optical study, magnetic and antibacterial activity. J. Mol. Struct. 2018, 1152, 294-302. [CrossRef]

108. Huang, P.-J.; Natori, Y.; Kitagawa, Y.; Sekine, Y.; Kosaka, W.; Miyasaka, H. One-dimensional chains of paddlewheel-type dichromium(II,II) tetraacetate complexes: Study of electronic structure influenced by sand p-donation of axial linkers. Inorg. Chem. 2018, 57, 5371-5379. [CrossRef]

109. Sieb, D.; Baker, R.W.; Wadepohl, H.; Enders, M. Naphthyridine cyclopentadienyl chromium complexes as single-site catalyst for the formation of ultrhigh molecular weight polyethylene. Organometallics 2012, 31, 7368-7374. [CrossRef] 
110. Cabez, J.A.; del Rio, I.; Peréz-Carreño, E.; Pruneda, V. Reductive dimerization of triruthenium clusters containing cationic aromatic N-heterocyclic ligands. Chem. Eur. J. 2010, 16, 5425-5436. [CrossRef]

111. Hideki, O.; Tsubasa, S.; Kiyoshi, T. A novel photo-driven hydrogenation reaction of an NAD(+)-type complex toward artificial photosynthesis. Front. Chem. 2019, 7. [CrossRef]

112. Zhu, S.; Moreno, K.X.; Jenkins, R.M.; Walmsley, J.A. Interactions of 1,5-naphthyridine with $\mathrm{Pd}(\mathrm{en}) \mathrm{Cl} 2$ or [PD(en) (H2O)2](NO3)2 in aqueous solution. Dalton Trans. 2008, 6401-6408. [CrossRef] [PubMed]

113. Poloek, A.; Chen, C.-T.; Chen, C.-T. New platinum complexes for hybrid white organic light-emiting diodes. Proc. SPIE 2019, 8829, 88291R-1.

114. Araki, H.; Tsuge, K.; Sasaki, Y.; Ishizaka, S.; Kitamura, N. Luminiscence ranging, from red to blue: Aseries of cooper (I)-halide complexes having rhombic $\{\mathrm{Cu} 2(\mathrm{n}-\mathrm{X}) 2\}(\mathrm{X}=\mathrm{Br}$ and I) units with $N$-heteroaromatic ligands. Inorg. Chem. 2005, 44, 9667-9675. [CrossRef] [PubMed]

115. Chen, C.; Wang, K.; Jiang, P.; Song, G.; Zhu, H. Synthesis, cristal structures and photophysical propierties of novel copper (I) complexes with 4-diphenylphosphino-1,5-naphthyridide ligands. Inorg. Chem. Commun. 2012, 17, 116-119. [CrossRef]

116. Djuric, S.; Vojnovic, S.; Pavic, A.; Mojicevic, M.; Wadepohl,H.; Savic, N.D.; Popsavin, M.; Nikodinovic-Runic, J.; Djuran, M.I.; Glisic, B.D. New polynuclear 1,5-naphthyridine-silver(I) complexes as potential antimicrobial agents: The key role of the nature of donor coordinated to the metal center. J. Inorg. Biochem. 2020, 203, 110872. [CrossRef]

117. Pyykkö, P.; Zaleski-Ejgierd, P. From nanostrip to nanorings: The elastic propierties of gold-glued polyauronaphthyridines and polyacenes. Phys. Chem. Chem. Phys. 2008, 10, 114-120. [CrossRef] [PubMed]

118. Matsui, J.; Sodeyama, T.; Saiki, Y.; Miyazawa, T.; Yamada, T.; Tamaki, K.; Murashima, T. Face to face porphyrin moieties assembled with spacing for pyrazine recognition in molecularly imprinted polymers. Biosens. Bioelectron. 2009, 25, 635-639. [CrossRef]

119. Mobinikhaledi, A.; Foroughifar, N. Preparation and characterization of CO (II), Ni (II) and Zn (II) complexes containing diazine ligands. Asian J. Chem. 2003, 15, 455-458.

120. Wei, H.; Zhao, Z.; Wei, C.; Yu, G.; Liu, Z.; Zhang, B.; Bian, J.; Bian, Z.; Huang, C. Antiphotobleaching: A type of structurally rigid chromophore ready for constructing highly luminescent and highly photostable Europium complexes. Adv. Funct. Mater. 2016, 26, 2085-2096. [CrossRef]

121. Huang, C. Rare Earth Coordination Chemistry; John Wiley \& Sons, Ltd.: Chichester, UK, 2010.

122. Bi, Y.; Chen, C.; Zhao, Y.-F.; Zhang, Y.-Q.; Jiang, S.-D.; Wang, B.-W.; Han, J.-B.; Sun, J.-L.; Bian, Z.-Q.; Wang, Z.-M.; et al. Thermostability and photoluminescence of Dy(III) single-molecule magnets under a magnetic field. Chem. Sci. 2016, 7, 5020-5031. [CrossRef]

123. Grandl, M.; Sun, Y.; Pammer, F. Electronic and structural properties of $\mathrm{N} \rightarrow \mathrm{B}$-ladder boranes with high electron affinity. Org. Chem. Front. 2018, 5, 336-352. [CrossRef]

124. Tai, C.-K.; Chou, Y.-M.; Wang, B.-C. Investigation of photophysical propierties of mer-tris(8-hydroxyquinolinato)aluminium (III) and its derivatives: DFT and TD-DFT calculations. J. Lumin. 2011, 131, 169-176. [CrossRef]

125. Lee, H.; Jeong, K.; Cho, S.W.; Yi, Y. Theoretical study on the effects of nitrogen and methyl substitution on tris-(8-hydroxyquinoline) aluminium: An efficient exciton blocking layer for organic photovoltaic cells. J. Chem. Phys. 2012, 137, 034704. [CrossRef] [PubMed]

126. Wang, L.; Wang, H. Planar mono-, di-, aza- and phospha-naphthalene: Structure and aromaticity. J. Quantum Chem. 2007, 107, 1846-1855. [CrossRef]

127. Bootsma, A.N.; Wheeler, S.E. Tuning Stacking Interactions between Asp-Arg Salt Bridges and Heterocyclic Drug Fragments. J. Chem. Inf. Model. 2019, 59, 149-158. [CrossRef]

128. Lu, R.-F.; Boëthius, G.; Wen, S.-H.; Su, Y.; Deng, W.-Q. Improved organic hydrogen carriers with superior thermodynamic propierties. Chem. Commun. 2009, 1751-1753. [CrossRef] [PubMed]

129. Maclagan, R.G.A.R.; Gronert, S.; Meot-Ner, M. Protonated polycyclic aromatic nitrogen heterocyclics: Proton affinities, polarizabilities, and atomic and ring charges of 1-5-ring ions. J. Phys. Chem. A 2015, 119, 127-139. [CrossRef] [PubMed]

130. Whyte, S.A.; Mosey, N.J. Behavior of two-dimensional hydrogen-bonded networks under shear conditions: A first-principles molecular dynamics study. J. Phys. Chem. C 2015, 119, 350-364. [CrossRef] 
131. Kenny, P.W.; Montanari, C.A.; Prokopczyk, I.M.; Ribeiro, J.F.R.; Sartori, G. Rodrigues hydrogen bond basicity prediction for medicinal chemistry design. J. Med. Chem. 2016, 59, 4278-4288. [CrossRef]

132. Toulmin, A.; Wood, J.M.; Kenny, P.W. Toward prediction of alkane/wáter partition coefficients. J. Med. Chem. 2008, 51, 3720-3730. [CrossRef]

133. Heidarnezhad, Z.; Ganiev, I.; Obidov, Z.; Heidarnezhad, F.; Sharifi, M.S. A theoretical study of NBO analysis and solvation effects on tautomerism stability of 4,8-dioxygenated 1,5-napththyridine. Orient. J. Chem. 2012, 28, 1597-1604. [CrossRef]

134. Tsukasaki, M.; Yamada, A.; Yoshimura, K.; Miyazono, A.; Yamamoto, M.; Takama, M.; Miyamoto, Y.; Morimura, N.; Kamijo, R. Nephronectin expression is regulated by SMAD signaling in osteoblast-like MC3T3-E1 cells. Biochem. Biophys. Res. Commun. 2012, 425, 390-392. [CrossRef] [PubMed]

135. Konovalov, B.; Zivkovic, M.D.; Milovanovic, J.Z.; Djordjevic, D.B.; Arsenijevic, A.N.; Vasic, I.R.; Janjic, G.V.; Franich, A.; Manojlovic, D.; Skrivanj, S.; et al. Synthesis, cytotoxic activity and DNA interaction studies of new dinuclear platinum(II) complexes with an aromatic 1,5-naphthyridine bridging ligand: DNA binding mode of polynuclear platinum(II) complexes in relation to the complex structure. Dalton Trans. 2018, 47, 15091-15102. [PubMed]

136. Nunes, M.C.; Goldring, J.P.; Doerig, C.; Scherf, A. A novel protein kinase family in Plasmodium falciparum is differentially transcribed and secreted to various cellular compartments of the host cell. Mol. Microbiol. 2007, 63, 391-403. [CrossRef] [PubMed]

137. Jin, J.; Wang, Y.; Wang, F.; Kerns, J.K.; Vinader, V.M.; Hancock, A.P.; Lindon, M.J.; Stevenson, G.I.; Morrow, D.M.; Rao, P.; et al. Oxazolidinones as novel human CCR8 antagonists. Bioorg. Med. Chem. Lett. 2007, 17, 1722-1725. [CrossRef] [PubMed]

138. Peng, J.; Hu, Q.; Gu, C.; Liu, B.; Jin, F.; Yuan, J.; Feng, J.; Zhang, L.; Lan, J.; Dong, Q.; et al. Discovery of potent and orally bioavailable inhibitors of Human Uric Acid Transporter 1 (hURAT1) and binding mode prediction using homology model. Bioorg. Med. Chem. Lett. 2016, 26, 277-282. [CrossRef]

139. Tang, C.W.; Vanslyke, S.A. Organic electroluminescent diodes. Appl. Phys. Lett. 1987, 51, 913-915. [CrossRef]

140. Lee, C.-C.; Yuan, C.-H.; Liu, S.-W.; Shih, Y.-S. Efficient deep blue organic light-emitting diodes based on wide band gap 4-hydroxy-8-methyl-1,5-naphthyridine aluminium chelate as emitting and electron transporting layer. J. Disp. Technol. 2011, 7, 454-458. [CrossRef]

141. Venkatanarayanan, A.; Martin, A.; Keyes, T.E.; Forster, R.J. Electrochemiluminiscence properties of a carboxy functionalisez BODIPY. Electrochem. Commun. 2012, 21, 46-49. [CrossRef]

142. Poloek, A.; Wang, C.; Chang, Y.-T.; Lin, C.-W.; Chen, C.-T.; Chen, C.-T. New platinum complexes exhibiting host dependent photoluminescence as single dopants in double emitting layer, voltage independent hybrid white electroluminescence devices. J. Mater. Chem. C 2015, 3, 11163-11177. [CrossRef]

143. Liu, S.-W.; Lee, C.-C.; Lin, C.-F.; Huang, J.-C.; Chen, C.-T.; Lee, J.-H. 4-Hydroxy-8-methyl-1,5-naphthyridine aluminium chelate: A morphologically stable and efficient exciton-blocking material for organic photovoltaics with prolonged lifetime. J. Mater. Chem. 2010, 20,7800-7806. [CrossRef]

144. Kim, J.H.; Choi, M.-W.; Yoon, W.S.; Oh, S.; Hong, S.H.; Park, S.Y. Structural and electronic origin of bis-lactam-based high-performance organic thin-film transistors. ACS Appl. Mater. Inter. 2019, 11, 8301-8309. [CrossRef] [PubMed]

145. Araujo, C.M.; Simone, D.L.; Konezny, S.J.; Shim, A.; Crabtree, R.H.; Soloveichik, G.L.; Batista, V.S. Fuel selection for a regenrative organic fuel cell/flow battery: Thermodynamic considerations. Energy Environ. Sci. 2012, 5, 9534-9542. [CrossRef]

146. Park, M.S.; Kang, Y.-S.; Im, D.; Doo, S.-G.; Chang, H. Design of novel additives and nonaqueous solvents for lithium-ion batteries through screening of cyclic organic molecules: An ab initio study of redox potentials. Phys. Chem. Chem. Phys. 2014, 16, 22391-22398. [CrossRef] [PubMed]

(C) 2020 by the authors. Licensee MDPI, Basel, Switzerland. This article is an open access article distributed under the terms and conditions of the Creative Commons Attribution (CC BY) license (http://creativecommons.org/licenses/by/4.0/). 